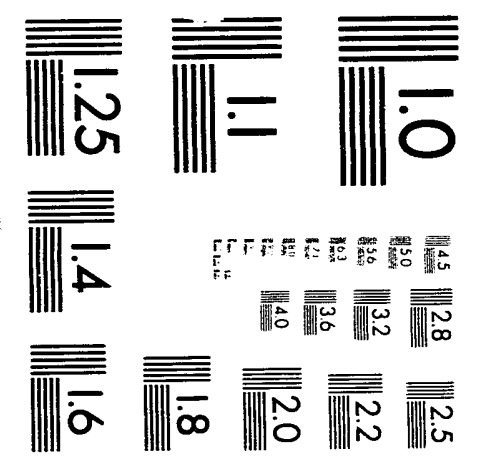



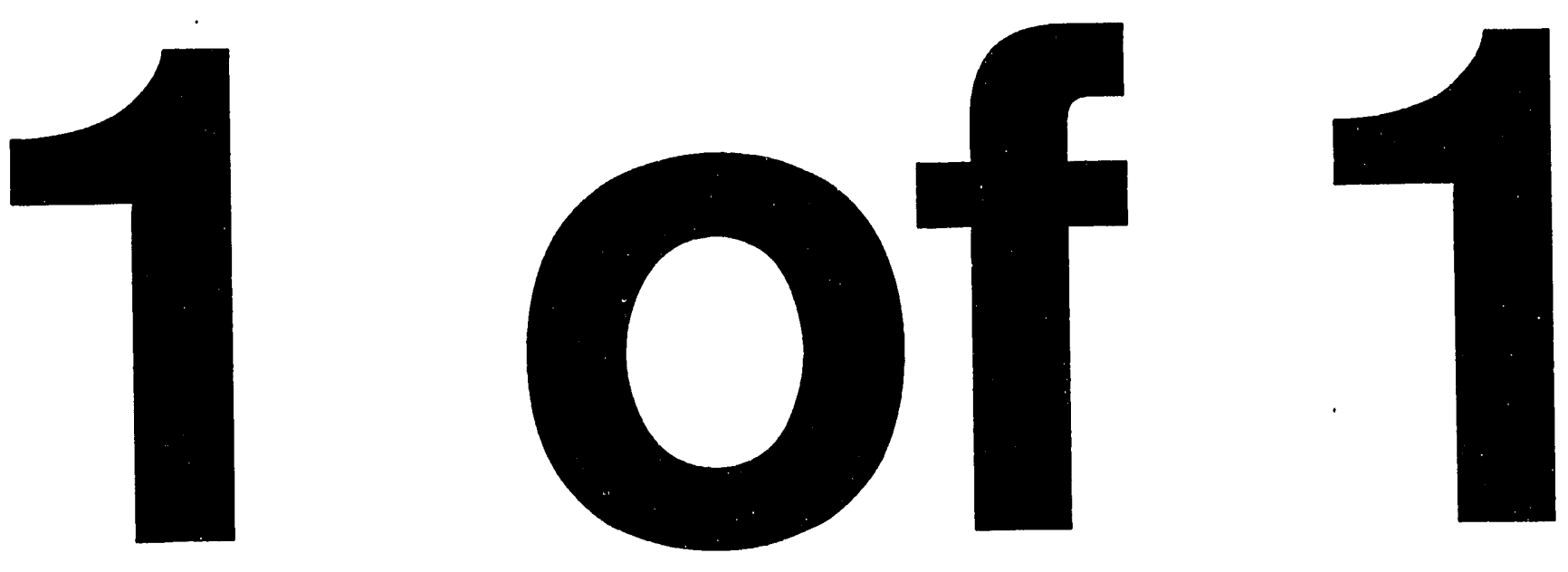


\section{ENVIRONMENTAL ASSESSMENT OF Remedial Action at the INACTIVE URANIFEROUS LIGNITE ASHING SITES AT Belfield and Bowman, North Dakota}

September 1993

\section{DISCLAIMER}

\footnotetext{
This report was prepared as an account of work sponsored by an agency of the United States This report was prepared as an account of work sponsored by an agency of the United States employees, makes any warranty, express or implied, or assumes any legal liability or responsiemployees, makes any warranty, express or implied, or any information, apparatus, product, or process disclosed, or represents that its use would not infringe privately owned rights. Referprocess disclosed, or represents that its use would not infringe privately ow trade name, trademark, ence herein to necessarily constitute or imply its endorsement, recommanufacturer, or otherwise does not necessarily constitute or imply its endorsement, recom views and opinions of authors expressed herein do not necessarily state or reflect those of the United States Government or any agency thereof.
} 
FINAL ENVIRONMENTAL ASSESSMENT

\author{
OF \\ REMEDIAL ACTION \\ AT THE \\ INACTIVE URANIFEROUS LIGNITE \\ ASHING SITES \\ AT \\ BELFIELD AND BOWMAN, NORTH DAKOTA
}

September 1993

U.S. Department of Energy UMTRA Project Office Albuquerque, New Mexico 
Page

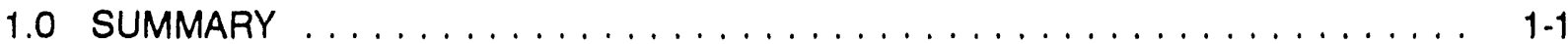

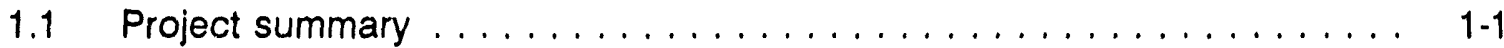

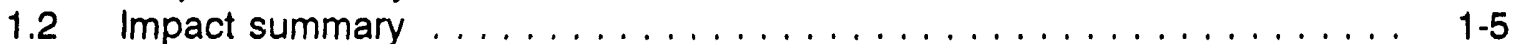

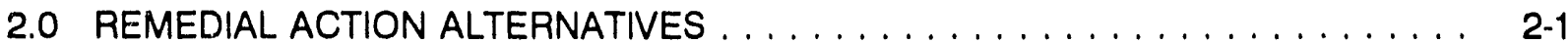

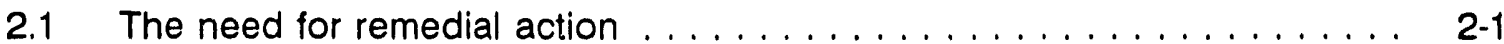

2.1.1 Background ......................... 2-1

2.1.2 Description of the Belfield and Bowman sites ........... 2-1

2.2 The proposed action-stabilization on the Bowman site . . . . . . . . . 2-2

2.2.1 Major construction activities . . . . . . . . . . . . . . . . 2-2

2.2.2 Final conditions ...................... 2-3

2.2.3 Borrow sites . . . . . . . . . . . . . . . . . . . . . . 2-7

2.3 Alternatives to the proposed action $\ldots \ldots \ldots \ldots \ldots \ldots \ldots \ldots \ldots$

2.3.1 No action .......................... 2-8

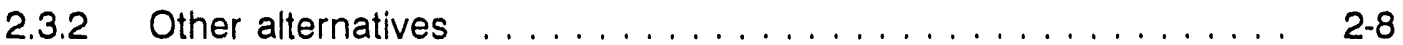

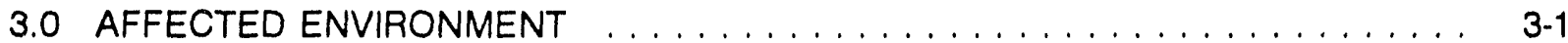

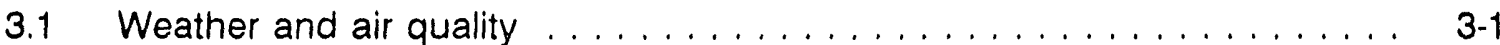

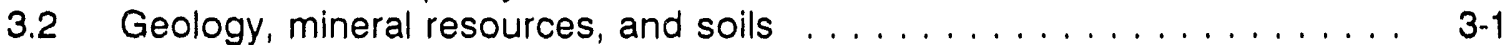

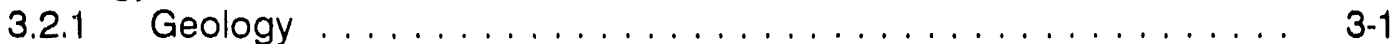

3.2.2 Mineral resources . . . . . . . . . . . . . . . . . . . . 3 3-2

3.2 .3 Soils . . . . . . . . . . . . . . . . . . . . . . . $3-2$

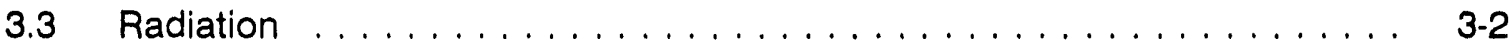

3.4 Groundwater . . . . . . . . . . . . . . . . . . . . . . . .

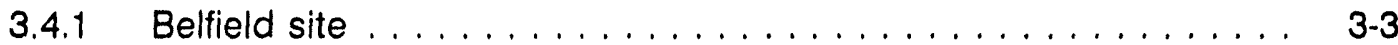

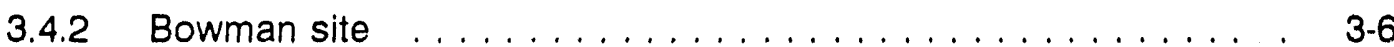

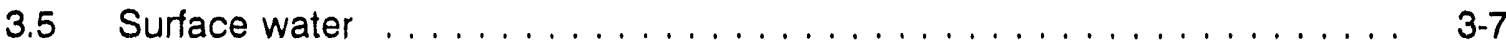

3.5.1 Surface water features . . . . . . . . . . . . . . . . . . . 3-8

3.5.2 Flood potential . . . . . . . . . . . . . . . . . . . . . . . 3-8

3.5.3 Surface water quality . . . . . . . . . . . . . . . . . . . $3-9$

3.6 Flora and fauna ... . . . . . . . . . . . . . . . . . . . . $3-9$

3.6.1 Belfield site . . . . . . . . . . . . . . . . . . . . . . $3-9$

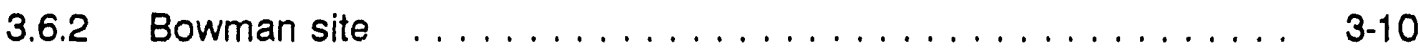

3.6.3 Borrow sites . . . . . . . . . . . . . . . . . . . . . . . $3-11$

3.6.4 Threatened or endangered species and other species

of concern ........................... $3-11$

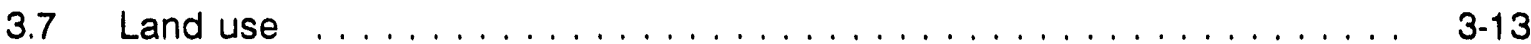

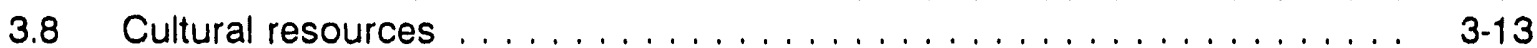

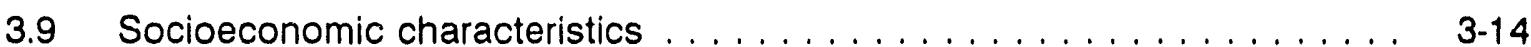

3.9.1 Population and housing . . . . . . . . . . . . . . . . . $3-14$

3.9.2 Employment ......................... $3-14$

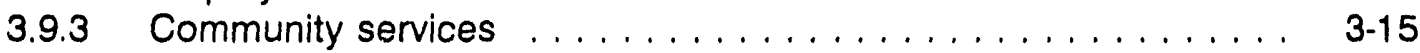




\section{TABLE OF CONTENTS (Concluded)}

Section

Page

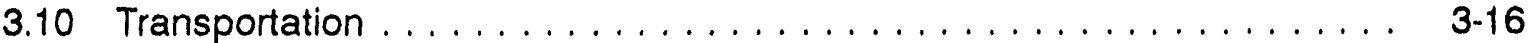

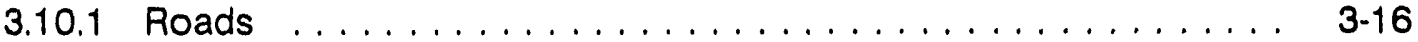

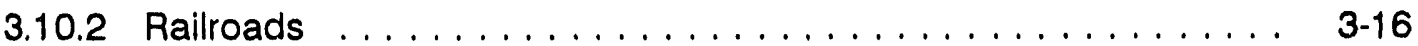

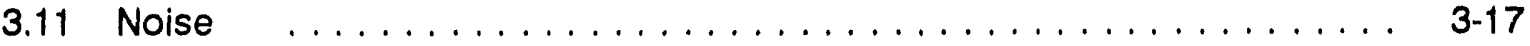

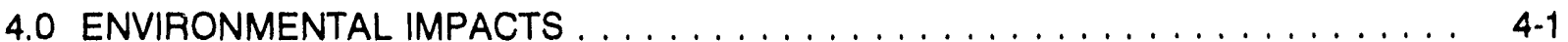

4.1 Introduction ............................... 4-1

4.1.1 The no action alternative $\ldots \ldots \ldots \ldots \ldots \ldots \ldots \ldots \ldots \ldots$ 4-2

4.2 Mineral resources . . . . . . . . . . . . . . . . . . . . . . . . . . . . 4-2

4.3 Radiation $\ldots \ldots \ldots \ldots \ldots \ldots \ldots \ldots \ldots \ldots \ldots \ldots \ldots \ldots \ldots . \ldots \ldots$

4.3.1 Radiation exposure pathways . . . . . . . . . . . . . 4-3

4.3.2 Short-term health risks . . . . . . . . . . . . . . . . . . . . . . 4 4-4

4.3.3 Long-term health risks . . . . . . . . . . . . . . . . . . . . . . 4-5

4.4 Groundwater . . . . . . . . . . . . . . . . . . . . . . 4.5

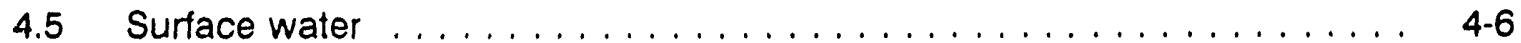

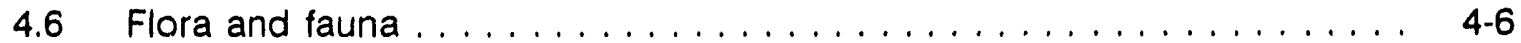

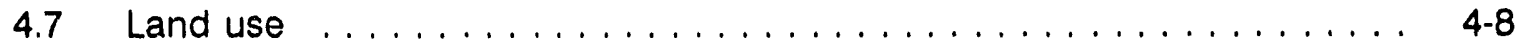

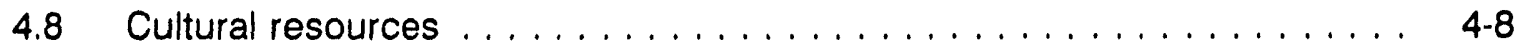

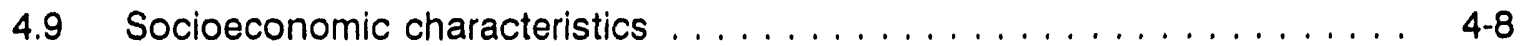

4.10 Transportation . . . . . . . . . . . . . . . . . . . . . . . . 4-9

4.11 Noise . . . . . . . . . . . . . . . . . . . . . . . . . . . . . . 4-9

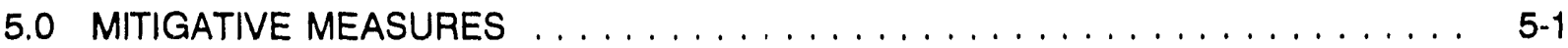

6.0 CONSULTATION, COORDINATION, AND LIST OF PREPARERS . . . . . . . . . . 6-1

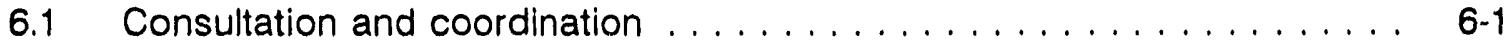

6.2 List of preparers . . . . . . . . . . . . . . . . . . . . . 6-2

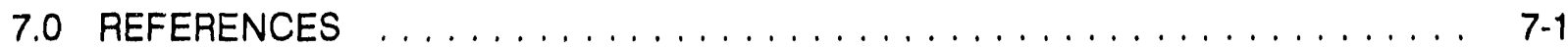

ATTACHMENT 1 FLOODPLAIN/WETLANDS ASSESSMENT

ATTACHMENT 2 U.S. FISH AND WILDLIFE SERVICE LETTERS

ATTACHMENT 3 ACRONYMS 


\section{LIST OF FIGURES}

Figure

Page

1.1 Location of the Belfield and Bowman, North Dakota, designated sites . . . . . 1-2

1.2 Location of the Belfield designated site, North Dakota . . . . . . . . . . . . . . . 1-3

1.3 Location of the Bowman designated site, North Dakota . . . . . . . . . . . . . . . 1-4

1.4 Locations of the Bowman designated site, and the Griffin and Bowman borrow sites in North Dakota . . . . . . . . . . . . . . . . . . . . . . . . . . . 1-6

2.1 Railroad transportation routes near Belfield and Bowman, North Dakota . . . . 2-4

2.2 Proposed disposal cell design Bowman disposal site, North Dakota . . . . . . . . 2 2-5

2.3 Typical cross sections for the proposed disposal cell and cover, Bowman disposal site, North Dakota.

\section{LIST OF TABLES}

Table

Page

3.1 Radiation and radioactivity levels, Belfield ashing site, North Dakota . . . . . . . 3-4

3.2 Radiation and radioactivity levels, Bowman ashing site, North Dakota . . . . . . 3-5

3.3 Summary of population for Stark and Bowman Counties, North Dakota for the period 1980-1992 


\subsection{SUMMARY}

\subsection{PROJECT SUMMARY}

The Uranium Mill Tailings Radiation Control Act (UMTRCA) of 1978 authorized the U.S. Department of Energy (DOE) to perform remedial actions at Belfield and Bowman inactive lignite ashing sites in southwestern North Dakota to reduce the potential public health impacts from the residual radioactivity remaining at the sites. The U.S. Environmental Protection Agency (EPA) promulgated standards (40 CFR 192) that contain measures to control the residual radioactive materials and other contaminated materials, and proposed standards to protect the groundwater from further degradation. Remedial action at the Belfield and Bowman sites must be performed in accordance with these standards and with the concurrence of the U.S. Nuclear Regulatory Commission (NRC) and the state of North Dakota.

The Belfield and Bowman designated sites (Figure 1.1), were used by Union Carbide and Kerr-McGee, respectively, to process uraniferous lignite in the 1960s. Uranium-rich ash from rotary kiln processing of the lignite was loaded into rail cars and transported to uranium mills in Rifle, Colorado, and Ambrosia Lake, New Mexico, respectively (DOE, $1983 a, b ;$ FBDU, 1981a,b). As a result of the ashing process, there is a total of 158,400 cubic yards $\left(\mathrm{yd}^{3}\right)\left[121,100\right.$ cubic meters $\left.\left(\mathrm{m}^{3}\right)\right]$ of radioactive ash-contaminated soils at the two sites.

The 10.7-acre [4.3-hectare (ha)] Belfield site, located about 1 mile (mi) [1.6 kilometers $(\mathrm{km})$ ] southeast of the town of Belfield in Stark County (Figure 1.2), is used for commercial, light industrial, and agricultural activities. Two original Union Carbide buildings are present at the designated site. One of the buildings was actively used during the ashing process and would be demolished during remedial action. The other building would be decontaminated and left intact. The entire 10.7-acre (4.33-ha) designated site area was contaminated during the ashing process. Windblown ashcontaminated soil covers an additional 21 acres ( $8.5 \mathrm{ha}$ ) around the site, which includes grazing land, wetlands, and a wooded habitat. Contaminated material quantities total $58,000 \mathrm{yd}^{3}\left(44,000 \mathrm{~m}^{3}\right)$ at the Belfield site.

The 12.1-acre (4.9-ha) Bowman site is about 7 miles $(11 \mathrm{~km})$ northwest of the town of Bowman in Bowman County. Bowman is about $65 \mathrm{mi}(104 \mathrm{~km})$ southwest of the Belfield site (Figure 1.3). The designated site is separated into two tracts by an unpaved county road and is overgrown with nonnative grasses. Structures and equipment used at the site have been removed, and only a small amount of concrete rubble and a few pieces of piping remain. Contaminated material quantities total $100,400 \mathrm{yd}^{3}\left(76,800 \mathrm{~m}^{3}\right)$ at the designated site. Windblown contamination covers an additional 59 acres (24 ha) around the site, including cultivated fields, wetlands, and a shelterbelt at the residence north of the site.

Groundwater at the two sites has been contaminated as a result of the lignite processing activities with concentrations of several hazardous constituents exceeding the proposed EPA groundwater standard maximum concentration limits (MCL). Although the affected aquifer is not used as a public drinking water supply, it is used for watering stock and other non-drinking domestic purposes. 


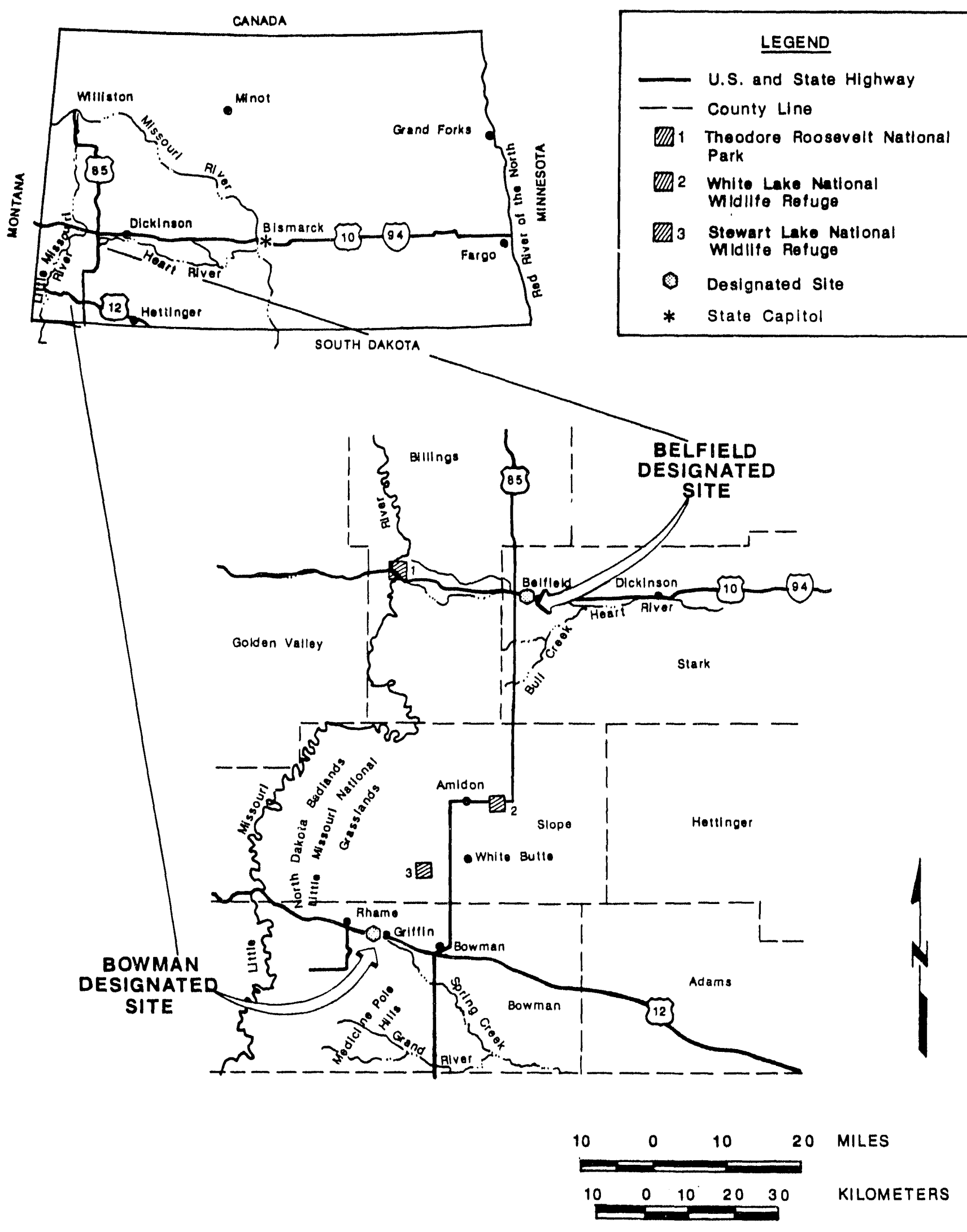

FIGURE 1.1

LOCATION OF THE BELFIELD AND BOWMAN NORTH DAKOTA, DESIGNATED SITES 


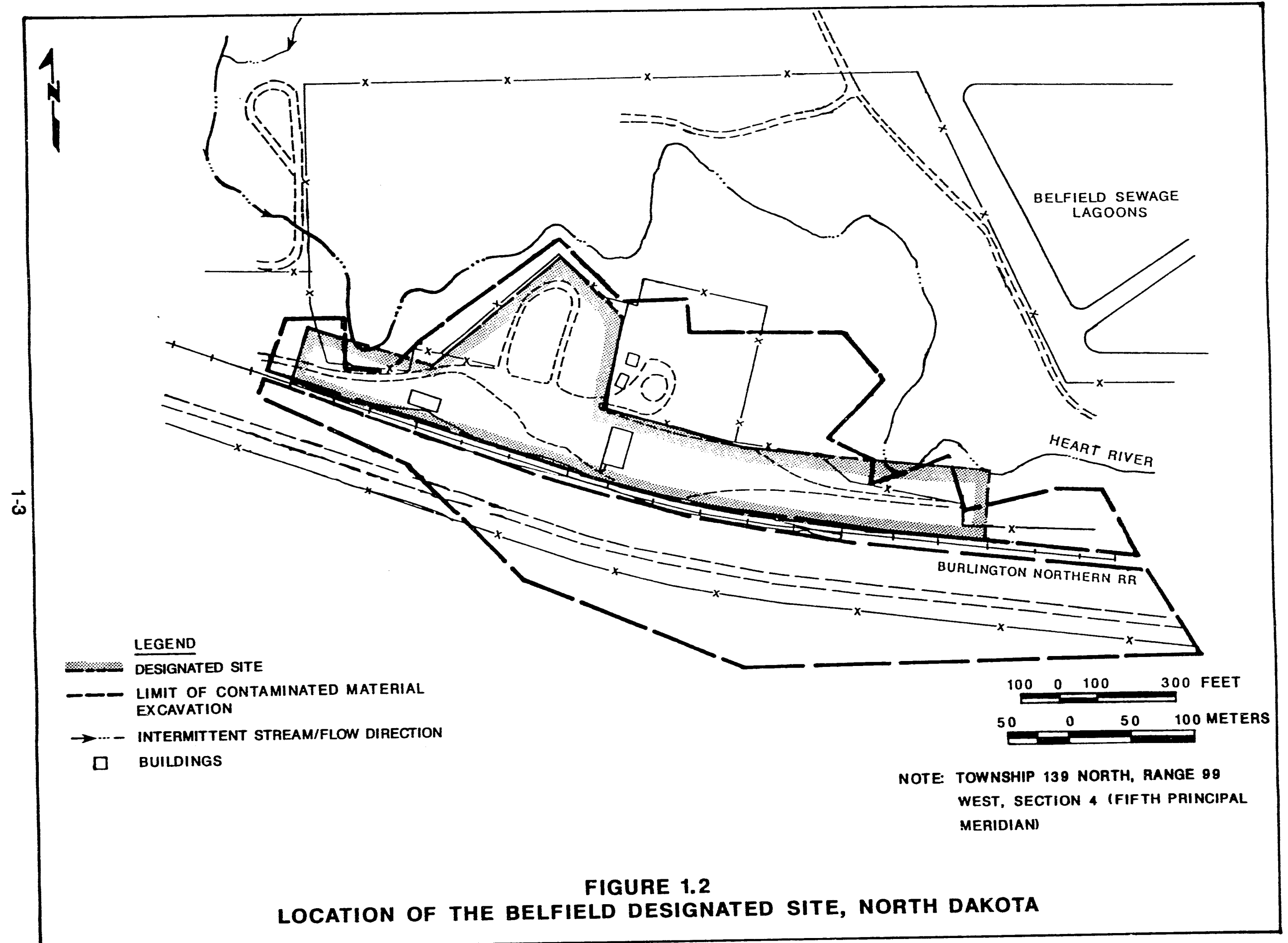




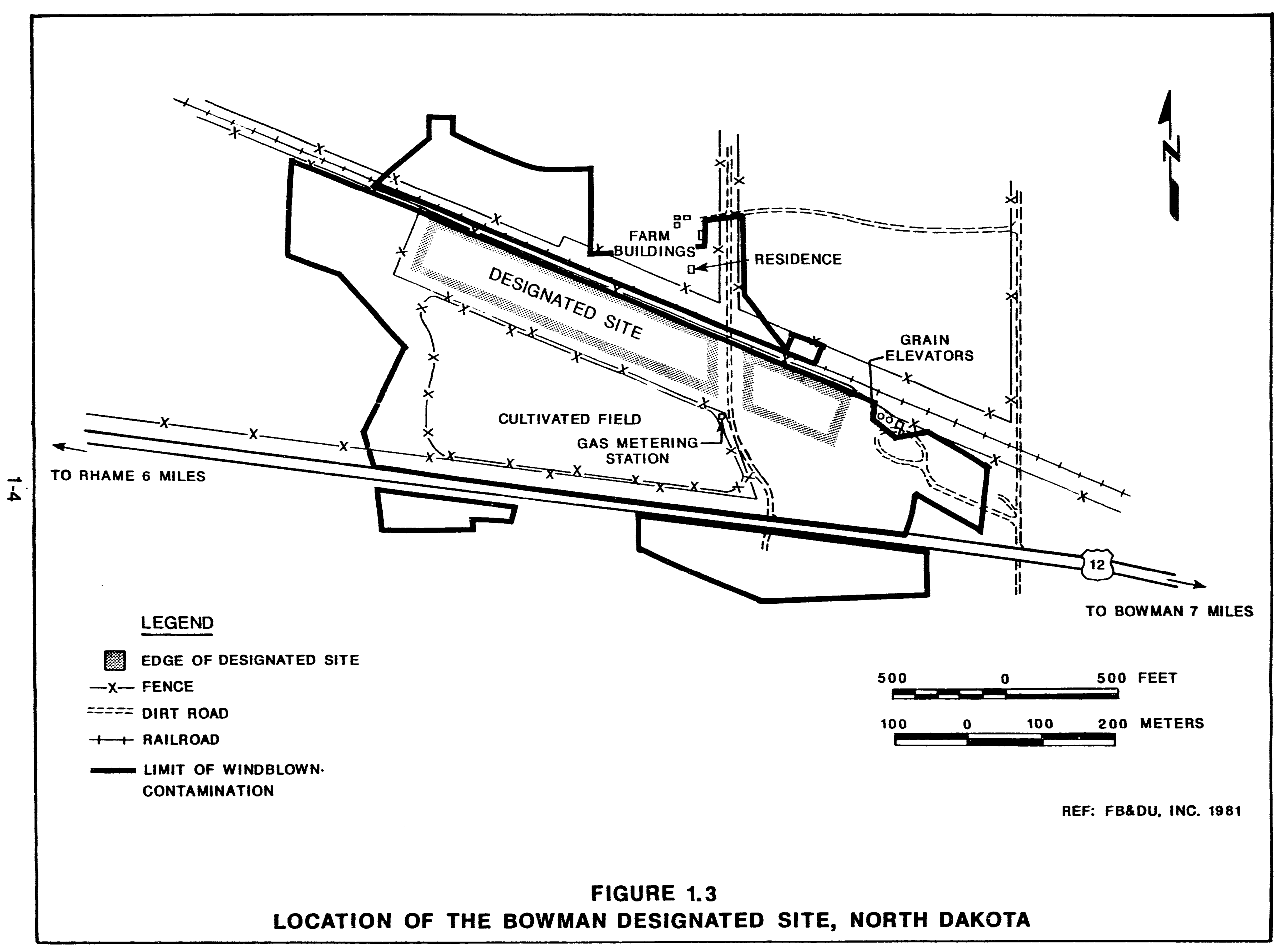


The proposed action is to relocate all contaminated materials from the Belfield site to the Bowman site for codisposal. The contaminated soil at Bowman would be left in place beneath the permanent disposal cell. The disposal cell would be covered with a low-permeability infiltration/radon barrier and erosion protection cover to ensure the long-term stability of the disposal cell, retard infiltration, reduce seepage of tailings fluids to groundwater, and prevent radon emanation. Two cover designs have been proposed for the disposal cell. The first design incorporates a cover of rock riprap as the erosion protection cover. The second design incorporates a rock riprap cover plus construction of a vegetative cover on the sides and/or top of the pile over the rock riprap erosion protection. At this time, evaluations of various vegetative covers are under design review.

Construction of the stabilized disposal cell would require the use of borrow materials (fine-grained material, sand, gravel, and rock). The Griffin and Bowman borrow sites would provide the material for the infiltration/radon barrier, the subbase material for constructing or upgrading all access and haul roads, and the reclamation soils at the Bowman site. The Griffin borrow site, 0.3 mile $(0.48$ kilometer) south of the Bowman site across U.S. Highway 12 (US-12) (Figure 1.4), is privately owned farmland. The Bowman borrow site, located 5 miles $(8 \mathrm{~km})$ southeast of the Bowman site (Figure 1.4) is privately owned and is leased for sand and gravel operations. A commercial quarry would be used to provide the sand and gravel for the filter and bedding layer and the rock riprap for the erosion protection layer, rock apron, and rock-lined drain; a known source is located 163 road $\mathrm{mi}(262 \mathrm{~km})$ south of the Bowman site. Scoria from local sources would be used to construct the access road at the Griffin borrow site, the temporary detour at the Belfield site, and for surfacing around the perimeter of the disposal cell (Figure 1.4).

Prior to initiation of activities at these sites, a plan for restoration of the borrow sites would be developed by the DOE in consultation with the appropriate regulatory agency, other authorities, and land owners. Disturbed areas would likely be backfilled, graded, and revegetated. The commercial quarry is a large-scale operation and is covered under a permit issued by the state of South Dakota. Impacts associated with this quarry are not considered in this document.

In addition to remedial action at the Belfield and Bowman sites, remedial action would be performed at nine vicinity properties. There are eight vicinity properties assisciated with the Belfield site and one vicinity property associated with the Bowman site. Vicinity properties are properties outside the designated site boundary that have beer contaminated by dispersed lignite ash or by the removal and use of the contaminated soils before the potential hazards were known. The potential environmental impacts associated with remedial actions at vicinity properties were previously assessed (DOE, 1985a) and are not considered in this environmental assessment (EA).

\subsection{IMPACT SUMMARY}

All impact assessments are based upon the assumption that the remedial action would take approximately 7 months to complete. Environmental impacts associated with proposed actions at the Belfield and Bowman sites would include the temporary loss of nonnative grassland; cultivated land; loss of wildlife habitat and disturbance of area 


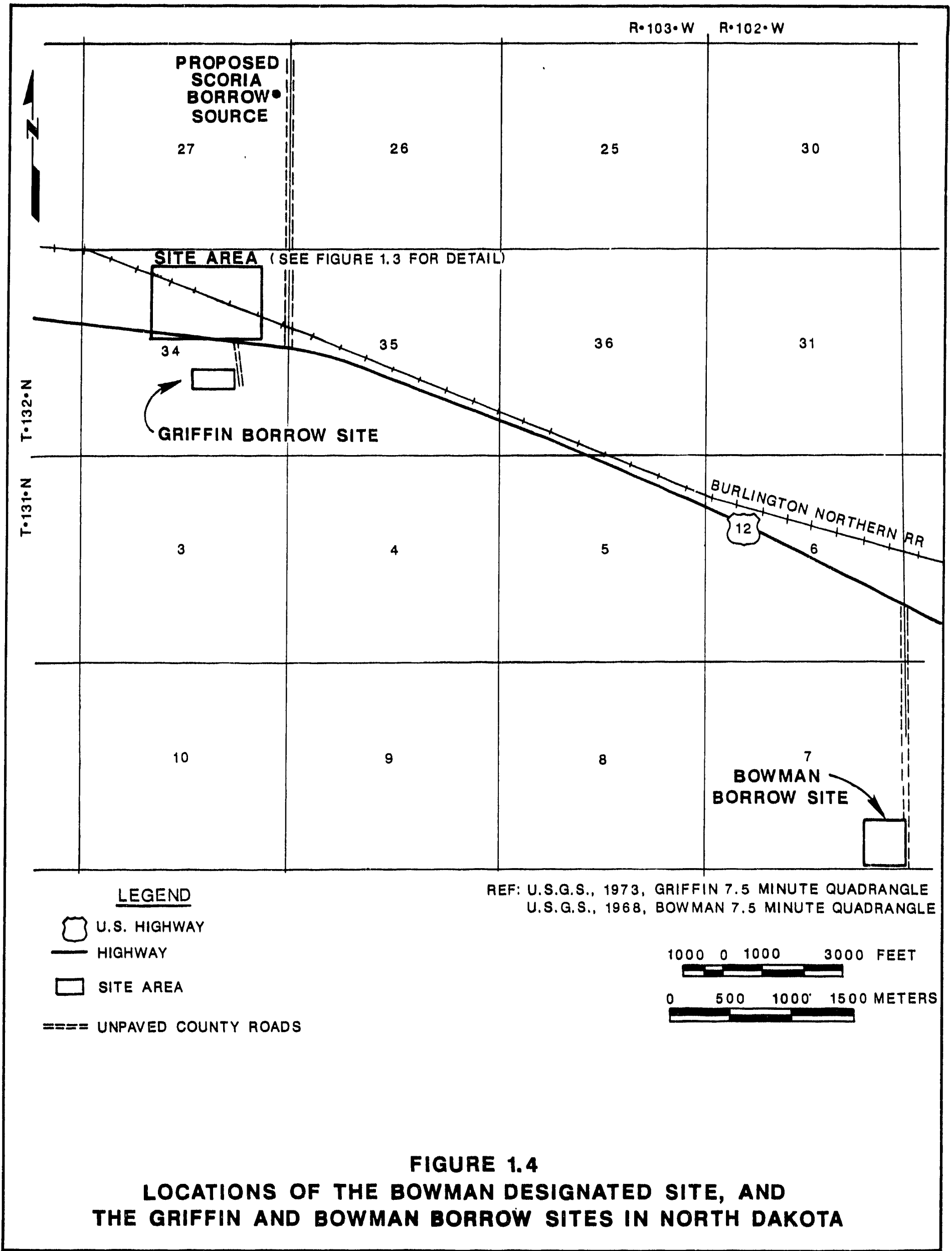


wildlife; generation of fugitive dust; and, increases in outdoor noise levels related to construction activities at the sites.

Adverse impacts of a permanent nature associated with the Bowman site include the visual impact that would be associated with the disposal cell. The permanent disposal cell would obstruct the southward view of the residents 500 feet $(\mathrm{ft})$ [150 meters $(\mathrm{m})$ ] north of the site. Permanent loss of existing and future uses of the 12.1-acre (4.9-ha) disposal site would also occur. The surrounding area is almost exclusively grazing and crop land. Access to the private property north of the site would not be hindered.

Positive impacts associated with both sites include a reduction in potential health effects related to the contaminated soils and the gradual reduction in concentrations of contaminants reaching shallow groundwater; the future availability of the currently contaminated Belfield lignite ashing site area for more productive uses; and, temporary increases in local expenditures and employment related to the remedial action. 


\subsection{REMEDIAL ACTION ALTERNATIVES}

\subsection{THE NEED FOR REMEDIAL ACTION}

\subsubsection{Background}

Title I of the UMTRCA required the Secretary of Energy to designate sites to be cleaned up, and authorized the DOE to enter into cooperative agreements with affected states or Indian tribes to clean up those inactive sites contaminated with uranium mill tailings. Title I also required the EPA to promulgate standards for these sites and defined the role of the NRC. These standards are to be met for up to 1000 years where reasonably achievable and, in any case, for at least 200 years. In developing these standards, the EPA determined that the primary objective for control of residual radioactive materials is isolation and stabilization to prevent their misuse by people and dispersion by natural forces; a secondary objective is to reduce radon emissions; and a third objective is the elimination of significant public exposure to gamma radiation.

On September 3,1985, the U.S. Tenth Circuit Court of Appeals remanded the portion of the standards relating to groundwater. Proposed groundwater standards were issued for comment by the EPA on September 24, 1987. Subpart A of the proposed standards sets forth the requirements for control of contaminant releases to the groundwater at the disposal sites. Subpart $B$ sets forth the requirements for remediating contaminated groundwater at the processing sites. Under the UMTRCA the DOE must comply with the proposed standards until standards are promulgated in final form.

\subsubsection{Description of the Belfield and Bowman sites}

\section{Belfield designated site}

The Belfield designated site is located in Stark County, in southwestern North Dakota (Figure 1.2). The 10.7-acre (4.3-ha) designated site and the land around it are privately owned. The North Branch of the Heart River is immediately north of the site, and the tracks of the Burlington Northern Railroad border the site on the south. Interstate $94(1-94)$ is approximately $0.9 \mathrm{mi}(0.6 \mathrm{~km})$ to the north and to the west is U.S. Highway 85 (US-85). On the designated site, two former Union Carbide buildings are present. One building is vacant, and the other is being utilized for equipment storage. To the north of the designated site is an oil and gas exploration company; to the west, the state highway department has a maintenance and equipment yard and an agricultural cooperative maintains liquid petroleum gas tanks. The area north of the site is used for grazing. The city's sewage lagoons are northeast of the site across the north branch of the Heart River. Off-site commercial areas are in Belfield and along US-85 south of 1-94.

\section{Bowman disposal site}

The Bowman designated site is $7 \mathrm{mi}(11 \mathrm{~km})$ northwest of the town of Bowman and immediately north of US-12 (Figure 1.3). The 12.1-acre (4.9-ha) designated site and 
all surrounding land are privately owned and used for agricultural purposes. The tracks of the Burlington Northern Railroad borders the site on the north. An unpaved county road that runs north-south separates the site into two tre-ts. The designated site land is not cultivated and the land immediately south of the site is fallow; other contaminated land outside of the designated site with vicinity property status is used for grazing. An inactive gas metering station is just outside the southeast corner of the western tract; and a grain elevator complex is $100 \mathrm{ft}(30 \mathrm{~m})$ east of the eastern tract. There is an occupied residence $500 \mathrm{ft}(152 \mathrm{~m})$ north of the designated site. Bowman is approximately $7 \mathrm{mi}(11 \mathrm{~km})$ east of the site and Rhame is approximately $8 \mathrm{mi}(13 \mathrm{~km})$ west of the site.

\subsection{THE PROPOSED ACTION-STABILIZATION ON THE BOWMAN SITE}

The proposed action is to relocate all contaminated materials from the Belfield site to the Bowman site for codisposal. The engineering design would comply with EPA standards; the major design features are summarized below. Design details are provided in the "Remedial Action Plan for Stabilization of the Inactive Uraniferous Lignite Processing Sites at Belfield and Bowman, North Dakota" (DOE, 1990).

\subsubsection{Major construction activities}

The remedial action would be performed using conventional construction practices and techniques that would comply with all applicable Federal, state, and local regulations. The remedial action would also ensure the safe and environmentally sound stabilization of the tailings and other contaminated materials in accordance with the EPA standards.

The major construction activities would include site preparation, construction of temporary drainage facilities, wastewater retention basins and other erosion control measures constructed at each site, transporting contaminated material and building demolition material from the Belfield site $65 \mathrm{mi}(105 \mathrm{~km})$ by truck to Bowman, construction of a temporary detour road at Belfield south of the railroad tracks, excavation of borrow materials, placement of a radon barrier and cover materials onto the disposal cell, and restoration of disturbed areas (excluding the commercial quarry pits).

The loaded $14 \mathrm{yd}^{3}\left(11 \mathrm{~m}^{3}\right)$ capacity haul trucks would exit the western end of the Belfield site and proceed west approximately $1300 \mathrm{ft}(400 \mathrm{~m})$ to the intersection with US-85, a major north-south transportation route. Turning south, the trucks would travel $65 \mathrm{mi}(104 \mathrm{~km})$ to the intersection of US-85 and US-12, and proceed west on US-12. The Bowman site is $7 \mathrm{mi}(11 \mathrm{~km})$ west of the intersection.

A second transportation option is under consideration. The Burlington Northern Railroad is adjacent to the Belfield and Bowman sites; the line typically carries grain cargo in unit trains that may reach $1 \mathrm{mi}(1.6 \mathrm{~km})$ in length. The Belfield materials would be loaded onto the train in specially constructed containers that are currently in use for this purpose at the Grand Junction site in Colorado. Each container would have a capacity of approximately $31 \mathrm{yd}^{3}\left(24 \mathrm{~m}^{3}\right)$ of contaminated materials. The materials would be transported west to Terry, Montana, an estimated $120 \mathrm{mi}(193 \mathrm{~km})$ from the Belfield site. The materials would then be transferred to a train travelling 
east to Bowman. There may be a waiting period of up to several days in Terry while sufficient cargo is being accumulated. The materials would be off-loaded in Bowman, adjacent to the disposal site. This transportation option would require the construction of special sidings that could accommodate the loading and unloading of the large containers. There are no closer transfer stations; the nearest transfer station east of Belfield is in Minnesota. Figure 2.1 provides the location of the railroad transfer station and area railroad routes.

\subsubsection{Final conditions}

The principal feature of the final conditions is the stabilization of the contaminated materials from the Belfield and Bowman sites in a location on and adjacent to the Bowman designated site (Figure 1.3). Disposal would be almost entirely above grade, except for some Bowman-contaminated materials left in place below the disposal cell (Figures 2.2 and 2.3). Contaminated soils and contaminated demolition rubble from both sites would be placed in the disposal cell along with contaminated soils from nine vicinity properties. The quantity of contaminated soils are as follows:

- $58,000 \mathrm{yd}^{3}\left(44,300 \mathrm{~m}^{3}\right)$ of contaminated Belfield site soils.

- $28,000 \mathrm{yd}^{3}\left(21,400 \mathrm{~m}^{3}\right)$ of contaminated soil left in place at the Bowman site.

- $100,000 \mathrm{yd}^{3}\left(76,500 \mathrm{~m}^{3}\right)$ of contaminated Bowman site soils outside the disposal cell footprint.

The rectangular disposal cell (including the cover and rock apron) would cover almost 10 acres ( $4 \mathrm{ha})$, measuring $740 \mathrm{ft}(226 \mathrm{~m})$ by $575 \mathrm{ft}(175 \mathrm{~m})$ with 20 percent sideslopes (5:1 horizontal to vertical) and 5 percent topslopes (to encourage runoff), rising to a maximum height of $35 \mathrm{ft}(11 \mathrm{~m})$ with an average height of $17.5 \mathrm{ft}(5.3 \mathrm{~m})$. The base of the disposal cell would be protected with a below-grade rock apron $15 \mathrm{ft}$ $(4.6 \mathrm{~m})$ wide, $3.5 \mathrm{ft}(1.1 \mathrm{~m})$ deep, and a 2.5 percent surface slope. See Figure 2.3 for typical cross sections. The rock erosion protection on the disposal cell and the rock apron were designed to withstand the Probable Maximum Flood (PMF) calculated for this area (DOE, 1992). The rock-lined drain at the southwest corner of the disposal cell, designed to channel water out of the trench (rock apron) on the southwest corner of the disposal site, would extend into a wet-meadow wetland. This wetland drains into an unnamed tributary of Spring Creek.

The contaminated materials would be protected by a multilayered cover (in ascending order; Figure 2.3), which would be composed of 1) a 1.5-ft $(0.46-\mathrm{m})$ thick layer of compacted earth (infiltration/radon barrier) to inhibit radon emanation and reduce infiltration; 2) a $0.5-\mathrm{ft}(0.15-\mathrm{m})$ thick layer of coarse sand (sand drain) for drainage; 3) a 4-ft $(1.2-\mathrm{m})$ thick layer of compacted select fill to help protect the infiltration/radon barrier from frost; 4$)$ a $0.5-\mathrm{ft}(0.15-\mathrm{m})$ thick layer of sand and gravel (filter and bedding) for drainage; and 5) a 1-ft $(0.3-\mathrm{m})$ thick layer of small rock (erosion protection barrier). Design of the infiltration/radon barrier will essentially permit no infiltration through the barrier, eliminating long-term leachate seepage from the disposal cell to the groundwater. The total frost protection design depth is $6 \mathrm{ft}$ $(1.8 \mathrm{~m}$ ) (see Figure 2.3). 


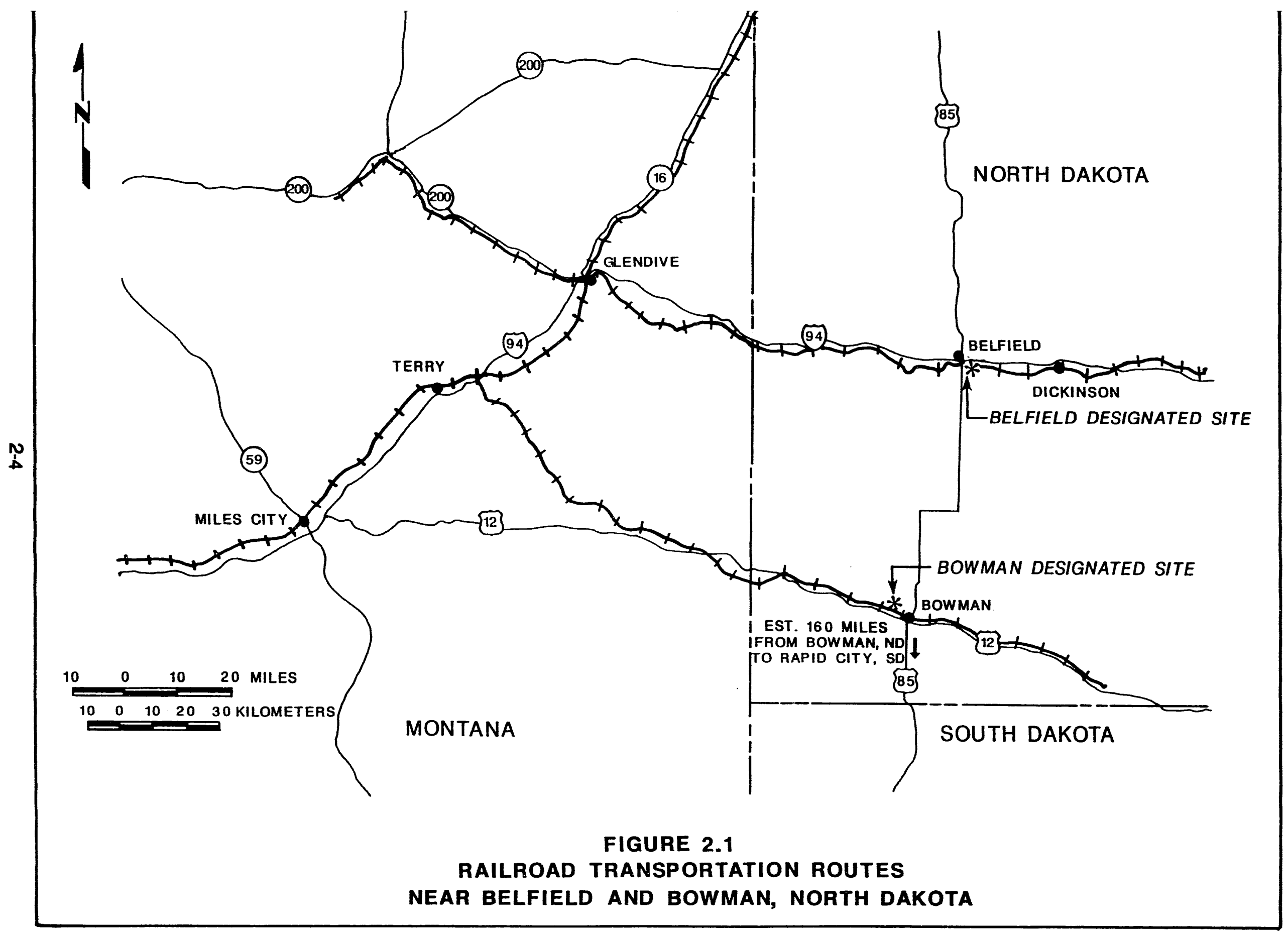




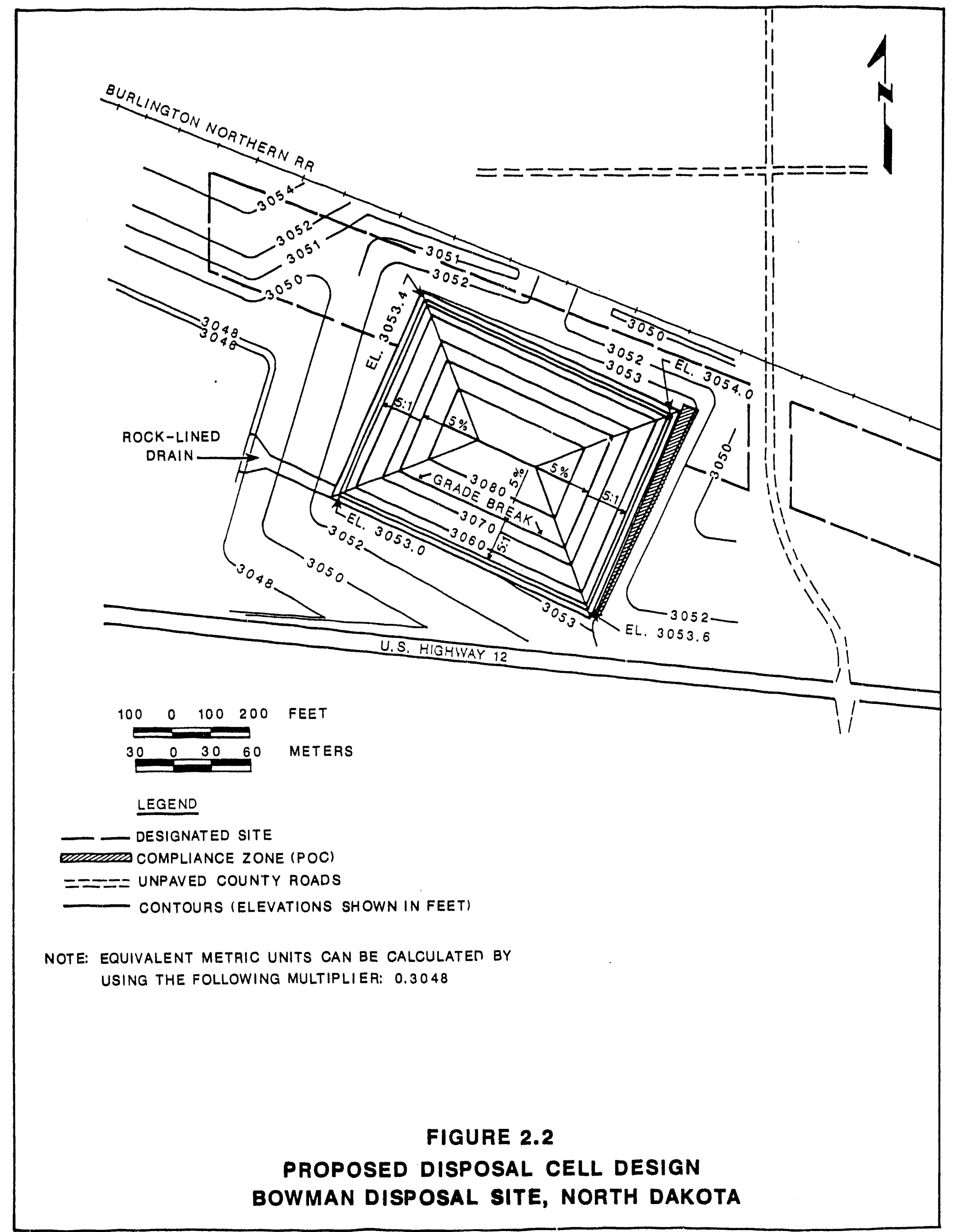




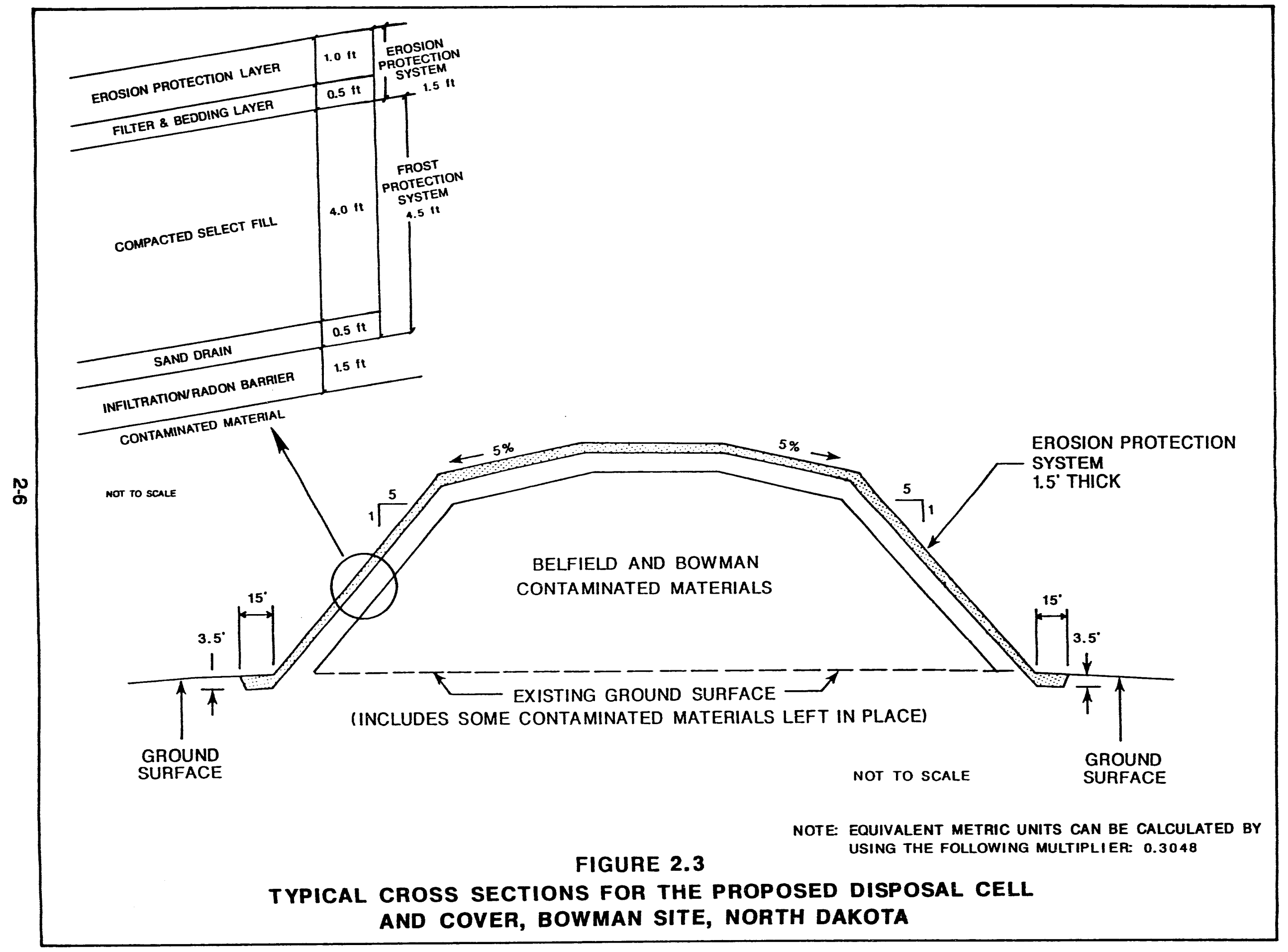


An alternate cover is being evaluated to lessen the visual impacts of the rock cover. The alternate cover would consist of one of the following two options: 1) use soil on the topslope of the pile, in conjunction with a sideslope consisting of the multilayered rock cover described above, or 2) use the rock-soll matrix on both the top and the sides of the pile (which involves choking the interstices of the top 4 inches [10 centimeters $(\mathrm{cm})$ ] of the riprap cover layer described above, with topsoil for seeding), producing a completely vegetated cell cover. These alternatives would not change the topslope, the footprint of the disposal cell design, or the performance of the infiltration/radon barrier.

After remedial action, all disturbed areas would be graded for positive drainage and reseeded. The Bowman borrow site and the commercial quarry would not be reclaimed as these are existing commercial facilities.

The proposed remedial action design presented in this EA is conceptual in nature and may change during the final design review process. However, the DOE anticipates that the actual final design would be similar to the conceptual design presented here, and that any changes in the final design would not alter the EA impact analysis.

\subsubsection{Borrow sites}

Three borrow sites have been identified for the final design, the Griffin and Bowman borrow sites and a commercial rock quarry. The Griffin borrow site is 0.3 road mi $(0.5 \mathrm{~km})$ south of the Bowman site and the Bowman commercial borrow site is $5 \mathrm{mi}$ $(8 \mathrm{~km})$ southeast. Earthen materials for the infiltration/radon barrier, select fill layers, and restoration at Bowman would be obtained from these sites. A commercial rock quarry under consideration at the time of this writing is located approximately

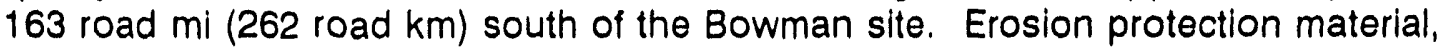
including riprap and bedding material would be obtained from this quarry.

Scoria from local sources would be used to construct the access road at the Griffin borrow site, the temporary detour at the Belfield site, and for surfacing around the perimeter of the disposal site. An estimated $6800 \mathrm{yd}^{3}\left(5200 \mathrm{~m}^{3}\right)$ would be needed for these activities.

An estimated $34,000 \mathrm{yd}^{3}\left(26,000 \mathrm{~m}^{3}\right)$ of soil to reclaim the excavated areas at the Belfield site also would be required. The Belfield area has topsolls that are sodium affected and in some cases have high salt content making them unsuitable for use as reclamation materials. Selection of soils for use as reclamation materials would necessitate identification and testing of the borrow soils to ensure they are suitable for their intended use. Specific borrow sources for the scoria and reclamation material would be determined prior to the remedial action. Because scoria occurs in both site areas (occurring as small erosional hill remnants), local sources would likely be used at each site. 


\subsection{ALTERNATIVES TO THE PROPOSED ACTION}

\subsubsection{No action}

The regulations (40 CFR 1502.14) implementing the National Environmental Policy Act (NEPA) require that the no action alternative be assessed. Taking no action at the Belfield and Bowman sites would leave the contaminated soils and other contaminated materials in their present condition, would not be consistent with UMTRCA, and would not comply with the EPA standards (40 CFR 192). The continued erosion and possible use of the contaminated materials may cause radiological contamination of other areas and could result in greater health risks than calculated for the proposed action.

\subsubsection{Other alternatives}

The DOE evaluated several disposal alternatives prior to the preparation of this EA (DOE, 1987). The rationale for eliminating these alternatives is summarized below.

Stabilization in place was considered as an alternative. This alternative would permanently stabilize all contaminated materials at the two individual designated sites using the same major design features as the design for the proposed action. The individual cell dimensions would be dependent on the volumes of material present at each site. Stabilization in place was rejected for the Belfield site tecause the designated site lies within the 100-year floodplain of the Heart River (FEMA, 1983). More rigorous design considerations and additional volumes of larger diameter rock would be needed to resist erosion during flooding or heavy precipitation, and to ensure that the Heart River wetland environment would not be destroyed, degraded, or lost.

Two possible alternate site locations were eliminated from further consideration when it was determined that these lands are owned by the North Dakota Board of University and School Lands; the state Constitution prohibits the sale of these lands and associated mineral rights without amending the Constitution. Depth to groundwater, added road construction, and longer haul distances also weighed against these alternative sites.

The Talkington Mine, an inactive open pit lignite mine was included for evaluation at the state's request. The mine is located $8 \mathrm{mi}(13 \mathrm{~km})$ northwest of the town of Belfield. It is scheduled for reclamation as part of North Dakota's Abandoned Mine Lands (AML) Program. However, the North Dakota State Department of Game and Fish expressed concerns over the adverse impacts on game populations and hunting, and North Dakota's projected AML Program schedule in 1986 was not compatible with the UMTRA Project schedule. These were significant factors in the decision not to consider the mine for further evaluation (DOE, 1987). Significant increases in the amount of road construction required for hauling the materials also weighed against this option. 


\subsection{AFFECTED ENVIRONMENT}

\subsection{WEATHER AND AIR QUALITY}

The average maximum annual temperatures recorded at Dickinson, North Dakota, $19 \mathrm{mi}$ (31 kilometers) east of the Belfield site, are $54^{\circ} \mathrm{F}\left(12.2^{\circ} \mathrm{C}\right)$ (maximum) and $30^{\circ} \mathrm{F}$ $\left(-1.0^{\circ} \mathrm{C}\right)$ (minimum) with extremes of $105^{\circ}$ and $-35^{\circ} \mathrm{F}\left(41^{\circ}\right.$ and $\left.-37^{\circ} \mathrm{C}\right)$ for the 30 -year period of record. For the same period of record, average annual temperatures and precipitation recorded at the Bowman weather station, $7 \mathrm{mi}(11 \mathrm{~km})$ east of the site, are almost identical to those recorded at Dickinson. At Dickinson, the average annual rainfall is 16 in $(40 \mathrm{~cm}), 80$ percent of which falls between April and September, with an average annual snowfall of $30 \mathrm{in}(80 \mathrm{~cm})$. The predominant wind direction recorded at Dickinson is from the west-northwest with an average annual wind speed of $13 \mathrm{mi}$ per hour $(20 \mathrm{~km} / \mathrm{hr})$. Wind data are not available from the Bowman station; however, wind direction and speed are expected to be similar to those recorded in the Dickinson area (NOAA, 1984a,b).

One air monitoring station is located in Dickinson $19 \mathrm{mi}(31 \mathrm{~km})$ east of Belfield, and another is at the Theodore Roosevelt National Park $10 \mathrm{mi}(16.6 \mathrm{~km})$ west of Belfield. Sulfur dioxide levels and total suspended particulates (TSP) concentrations were the only EPA priority pollutants mionitored. The Theodore Roosevelt National Park station and the Bowman station are no longer in operation. TSP is the only pollutant monitored at the Dickinson station. Concentrations of sulfur dioxide and TSD measured at these stations were well below the Federal and state air quality standards; levels of four other priority pollutants (nitrogen dioxide, carbon dioxide, ozone, and lead) are expected to be low given the rural nature of the region (NDSDH, 1987).

\subsection{GEOLOGY, MINERAL RESOURCES, AND SOILS}

\subsubsection{Geology}

The Belfield designated site lies within a narrow floodplain of the North Branch of the Heart River. The soils present are fluvial deposits that overlie similar material of the poorly consolidated weathered bedrock. Bedrock consists of interbedded silt, clays, sand, and lignite deposits of the Paleocene Sentinel Butte Formation. The Sentinal Butte Formation has an approximate total thickness of $450 \mathrm{ft}(137 \mathrm{~m})$ in the region (DOE, 1992).

The Bowman designated site is on a low drainage divide between two unnamed tributaries of Spring Creek. The site is underlain by 1 to $2 \mathrm{ft}(0.3$ to $0.6 \mathrm{~m})$ of silty clay soils and weathered bedrock of the Paleocene Bullion Creek Formation of the Fort Union Group. This formation consists of silty clay, sand, and lignite deposits in repeating alternating sequences. The Bullion Creek Formation unconformably overlies the Ludlow Formation, the oldest unit in the Fort Union Group. An unconfined aquifer system is present in the Bullion Creek and upper Ludow sediments. Three other confined aquifer systems occur in the underlying $1500 \mathrm{Ht}(457 \mathrm{~m})$ of the marine sediments of the Upper Cretaceous Hill Creek and Fox Hills (DOE, 1992). 
The nearest location of known capable faults is the Black Hills region. The largest recorded earthquake (magnitude 3.6) within a $124 \mathrm{ml}(200 \mathrm{~km}$ ) radius of the Bowman site occurred $76 \mathrm{mi}(123 \mathrm{~km})$ from the site (DOE, 1992).

\subsubsection{Mineral resources}

Mineral resources of economic value in the Belfield and Bowman areas include lignite coal, oll, and gas, uranlum, and sand and gravel (aggregate). Most subsurface mineral rights are privately owned throughout North Dakota (DOE, 1992).

There are several small producing petroleum fields north and west of Belfield; however, at the time of this writing, there are no known oil and gas leases in the immediate site area. Two deep lignite deposits as well as strippable lignite deposits underlie the Belfield area. However, the current industrial use of the site area, the proximity to the Burlington Northern Railroad tracks, and presence of shallow groundwater make the developmint of this resource unlikely. Important uranium ore reserves are present in the Belfieid area, although there aro no known economic deposits in the immediate site area (DOE, 1992).

Mineral resources in the vicinity of the Bowman site area are similar to those in the Belfield site area. However, economic deposits are not as common and there are no known uranium deposits. Mineral rights are principally owned by the Burlington Northern Rallroad (DOE, 1992).

\subsubsection{Soils}

In the Belfield site area, soils are low to moderately expansive clayey silts to silty clay floodplain deposits of the Savage series. These loams have a high natural fertility and small grains giown on these solls produce high yields (USDA, 1968). StrawHavre silty clay loams are found along the banks of the Heart River. These soils are subject to flooding and are not suitable for cultivation, but are sultable for grazing.

In the Belfield site area, Shambo-Arnegard silty clay loams are found forming good topsoil on fans and swales. These high-fertility loams are well suited for all crops (USDA, 1975).

The Bowman and Belfield site areas were evaluated by the state of North Dakota Soll Conservation Service office for the presence of prime or unique farmlands regulated under the Farmland Policy Protection Act (PL 97-98); none were found to be present.

\subsection{RADIATION}

Belfield and Bowman are sites where uraniferous lignite was burned in gas-fired kilns to produce an ash with sufficient uranium content to facilitate further processing. The ash was sent elsewhere for processing to extract the uranium. Uranium was not chemically extracted from the ash at Belfield or Bowman. Uranium mill tallings in the strict sense, the residue remaining of uranium ore following the chemical extraction of uranium, do not exist at these sites. The contaminated material at Belfield and Bowman consists of soll that was dusted with lignite ash from the kiln exhausts, and from windblown ash from storage plles and ash-handling operations. 
The radionuclides in the ash have resulted in elevated gamma radiation exposure levels at these sites. Tables 3.1 and 3.2 provide levels of contamination at the Belfield and Bowman sites, respectively. Exposure rates decrease with increasing distance from the sites, approaching background within $0.5 \mathrm{mi}(0.8 \mathrm{~km})$ of both sites in all directions.

The average depth of contaminated soil is $1.1 \mathrm{ft}(0.34 \mathrm{~m})$ at the Belfleld site and $1.2 \mathrm{ft}$ $(0.37 \mathrm{~m})$ at the Bowman site (DOE, 1989). There are isolated areas at both sites where deeper contaminated soils occur; these are a possible sludge pit area at the Belfield site (Mount, 1987) and areas where lignite ore was stockpiled at the Bowman site.

\subsection{GROUNDWATER}

As part of the compliance with the proposed EPA groundwater protection standards for remedial actions at inactive uranium processing sites (40 CFR 192), the DOE has characterized the hydrogeology, water quality, and water resources at the Belfield and Bowman sites. Hydrogeologic conditions and groundwater quality impacts resulting from the uranium ashing process and disposal activities at the Belfield and Bowman sites are summarized in this section.

\subsubsection{Belfield site}

The Belfield site is underlain by sediments of the Sentinel Butte Formation (uppermost unit of the Tertiary Fort Union Group) The Sentinel Butte Formation consists of an interbedded sequence of silty sandstone, sandy claystone, and silty claystone ("upper zone"), underlain by a lignite unit ("lignite zone"), that in turn overlies claystone of undetermined thickness.

Groundwater occurs in the upp er zone and the lignite zone under unconfined and semi-confined conditions with tater levels ranging from 15 to $38 \mathrm{ft}(5$ to $12 \mathrm{~m})$ below the surface. The groundwater system is recharged directly by precipitation, and seepage from intermittent streams and standing surface water. There is no evidence of discharge of groundwater to the land surface or surface water in the vicinity of the site. Groundwater in the upper zone generally flows toward the south and southeast, and groundwater in the lignite zone generally flows toward the east. The vertical hydraulic gradient beneath the Belfield site is downward toward the lignite zone. The average hydraulic conductivity calculated from slug tests in monitor wells completed in the upper zone was $0.7 \mathrm{ft} /$ day $\left(2.5 \times 10^{-4} \mathrm{~cm} / \mathrm{s}\right)$. The average hydraulic conductivity calculated from one of the monitor wells completed in the lignite zone was 2.6 feet/day $\left(9.2 \times 10^{-4} \mathrm{~cm} / \mathrm{s}\right)$. The average linear groundwater velocity for the upper zone was $0.07 \mathrm{ft} /$ day $\left(2.5 \times 10^{-5} \mathrm{~cm} / \mathrm{s}\right)$, and the average linear groundwater velocity for the lignite zone was $0.27 \mathrm{t} /$ day $\left(9.6 \times 10^{-5} \mathrm{~cm} / \mathrm{s}\right)$.

Background groundwater quality in the upper zone has been determined by chemical analysis of water samples collected from three monitor wells located upgradient from the site. Evaluation of groundwater quality data from background monitor wells completed in the upper zone shows that maximum background concentrations are below the MCLs except for lead and selenium. 
Table 3.1 Radiation and radioactivity levels, Belfield ashing site, North Dakota,

\begin{tabular}{|c|c|c|c|}
\hline & Range & Average & Source \\
\hline \multicolumn{4}{|l|}{ Gamma exposure rate $^{a}$} \\
\hline Background $^{b}$ & 11.4-13.2 microR/hr & $12.4 \mathrm{microR} / \mathrm{hr}$ & BFEC, $1986 a$ \\
\hline $\begin{array}{l}\text { On site contaminated } \\
\text { areas }\end{array}$ & $12-249 \mathrm{microR} / \mathrm{hr}$ & NA & BFEC, $1986 a$ \\
\hline \multicolumn{4}{|l|}{ Radon-222 } \\
\hline On site flux & $\begin{array}{c}1-63 \mathrm{pCl} / \mathrm{m}^{2} \mathrm{~s} \\
\left(0.0-2.33 \mathrm{~Bq} / \mathrm{m}^{2} \mathrm{~s}\right)\end{array}$ & $\begin{array}{c}20 \mathrm{pCl} / \mathrm{m}^{2} \mathrm{~s} \\
\left(0.74 \mathrm{~Bq} / \mathrm{m}^{2} \mathrm{~s}\right)\end{array}$ & FBDU, 1981a \\
\hline \multicolumn{4}{|l|}{ Soil radioactivity } \\
\hline$\frac{\text { Background }}{\text { Ra-226 }}^{\mathrm{b}}$ & $\begin{array}{c}1.0-1.9 \mathrm{pCl} / \mathrm{g} \\
(0.037-0.07 \mathrm{~Bq} / \mathrm{g})\end{array}$ & $\begin{array}{c}1.4 \mathrm{pCl} / \mathrm{g} \\
(0.05 \mathrm{~Bq} / \mathrm{g})\end{array}$ & BFEC, $1986 a$ \\
\hline Th-230d & $\begin{array}{c}1.8 \mathrm{pCl} / \mathrm{g} \\
(0.07 \mathrm{~Bq} / \mathrm{g})\end{array}$ & $\begin{array}{c}1.8 \mathrm{pCl} / \mathrm{g} \\
(0.07 \mathrm{~Bq} / \mathrm{g})\end{array}$ & BFEC, $1986 a$ \\
\hline$\frac{\text { On site }^{\theta}}{\text { Ra-226 }}$ & $\begin{array}{c}1.3-1374.1 \mathrm{pCl} / \mathrm{g} \\
(0.05-50.84 \mathrm{~Bq} / \mathrm{g})\end{array}$ & NA & BFEC, $1986 a$ \\
\hline \multicolumn{4}{|l|}{ Stream sediments } \\
\hline$\frac{\text { Heart River }}{\text { Ra-226 }}$ & $\begin{array}{c}1.3-5.1 \mathrm{pCl} / \mathrm{g} \\
(0.05-0.19 \mathrm{~Bq} / \mathrm{g})\end{array}$ & NA & BFEC, 1986a \\
\hline Th-230 & $\begin{array}{c}2.0-3.0 \mathrm{pCl} / \mathrm{g} \\
(0.07-0.11 \mathrm{~Bq} / \mathrm{g})\end{array}$ & NA & BFEC, $1986 a$ \\
\hline
\end{tabular}

Taken $3 \mathrm{H}(0.91 \mathrm{~m})$ above the ground.

${ }^{\text {b Areas }} 1.5 \mathrm{ml}(2.4 \mathrm{~km})$ trom ashing site.

CLong-term radon measurements will be made before, during, and after remedial action.

'Single measurement only.

The uranlum decay chain is in equilibrium at Belfield and Bowman.

Nole: $\quad$ mioroR/hr $=$ micrornantgens/hour

$\mathrm{pCl} / \mathrm{m}^{2} \mathrm{~s}=$ pleocurles/meter squared-second

$\mathrm{PCl} / \mathrm{g}=$ picoriurles/gram

NA $=$ not avallable

$1 \mathrm{pCl}=0.037$ bociguerels $(\mathrm{Bq})$

$1 \mathrm{~Bq} \quad=1$ disintegration per second 
Table 3.2 Radlation and radioactivity levels, Bowman ashing site, North Dakota

\begin{tabular}{|c|c|c|c|}
\hline & Range & Average & Source \\
\hline \multicolumn{4}{|l|}{ Gamma exposure rate $^{a}$} \\
\hline Background $^{b}$ & 11.9-13.4 microR/hr & $12.8 \mathrm{microR} / \mathrm{hr}$ & BFEC, $1986 b$ \\
\hline $\begin{array}{l}\text { On site contaminated } \\
\text { areas }\end{array}$ & $11-358 \mathrm{microR} / \mathrm{hr}$ & NA & BFEC, 1986b \\
\hline \multicolumn{4}{|l|}{ Radon-22:'c } \\
\hline On site flux & $\begin{array}{c}15-94 \mathrm{pCi} / \mathrm{m}^{2} \mathrm{~s} \\
\left(0.56-3.48 \mathrm{~Bq} / \mathrm{m}^{2} \mathrm{~s}\right)\end{array}$ & $\begin{array}{c}58 \mathrm{pCl} / \mathrm{m}^{2} \mathrm{~s} \\
\left(2.15 \mathrm{~Bq} / \mathrm{m}^{2} \mathrm{~s}\right)\end{array}$ & FBDU, 1981b \\
\hline \multicolumn{4}{|l|}{ Soil radioactivity $(\mathrm{pCi} / \mathrm{g})$} \\
\hline \multicolumn{4}{|l|}{ Background $^{b}$} \\
\hline Ra-226 & $\begin{array}{c}0.8-2.0 \mathrm{pCl} / \mathrm{g} \\
(0.03-0.07 \mathrm{~Bq} / \mathrm{g})\end{array}$ & $\begin{array}{c}1.4 \mathrm{pCl} / \mathrm{g} \\
(0.52 \mathrm{~Bq} / \mathrm{g})\end{array}$ & BFEC, 1986b \\
\hline Th-230 & $\begin{array}{c}1.0-1.9 \mathrm{pCl} / \mathrm{g} \\
(0.04-0.07 \mathrm{~Bq} / \mathrm{g})\end{array}$ & $\begin{array}{c}1.4 \mathrm{pCl} / \mathrm{g} \\
(0.05 \mathrm{~Bq} / \mathrm{g})\end{array}$ & BFEC, $1986 \mathrm{~b}$ \\
\hline \multicolumn{4}{|l|}{$\underline{\text { On site }}^{d}$} \\
\hline $\mathrm{Ra}-226$ & $\begin{array}{c}0.4 .415 .0 \mathrm{pCl} / \mathrm{g} \\
(0.01-15.36 \mathrm{~Bq} / \mathrm{g})\end{array}$ & $\begin{array}{l}42.8 \mathrm{pCl} / \mathrm{g} \\
(1.6 \mathrm{~Bq} / \mathrm{g})\end{array}$ & BFEC, $1986 b$ \\
\hline
\end{tabular}

\footnotetext{
Taken $3 \mathrm{ft}(0.91 \mathrm{~m})$ above the ground.

'Areas $1.5 \mathrm{ml}(2.4 \mathrm{~km})$ from ashing site.

¿Long-term radon measurements will be made before, during, and after remedial action.

dThe uranium decay chain is in equillbrium at Belfield and Bowman.

Note: $\quad \mathrm{microR} / \mathrm{hr}=$ microroentgens/hour

$\mathrm{pCl} / \mathrm{m}^{2} \mathrm{~s}=$ plcocuries/meter squared-second

$\mathrm{pCl} / \mathrm{g}=$ picocuries/gram

$\mathrm{NA} \quad=$ not available

$1 \mathrm{pCi} \quad=0.037$ becquerels $(\mathrm{Bq})$

$1 \mathrm{~Bq} \quad=1$ disintegration per second
} 
Concentrations of contaminants in the soil pore fluid were analyzed in a sample collected from a suction lysimeter to determine the source term. Concentrations of molybdenum, nitrate, selenium, and uranium exceeded the MCLs. (Concentrations of nitrate are probably related to agriculture (fertilizer) or effluent from nearby septic tanks.)

Contaminants in groundwater, related to the uranium processing activities, do not form a discrete plume in the upper zone downgradient from the processing site, but are concentrated in areas generally beneath and adjacent to the processing site. This is a result of the diffuse nature of the contaminant source related to the lignite ashing process. In the upper zone, average concentrations of chromium, molybdenum, selenium, and uranium exceeded the MCLs in the vicinity of the site. In the lignite zone, average concentrations of molybdenum and selenium exceeded the MCLs.

Shallow wells in the Sentinel Butte aquifer system provide water for stock watering and some domestic purposes, but not for drinking water supplies. The city of Belfield municipal water supply is derived from several wells within the city limits, at depths in excess of $1000 \mathrm{ft}(300 \mathrm{~m})$. These wells are located at least $1000 \mathrm{ft}(300 \mathrm{~m})$ upgradient from the site. Alternative water supplies in the vicinity of the site are available from deeper aquifer systems.

\subsubsection{Bowman site}

The Bowman site is underlain by sediments of the Bullion Creek Formation (part of the Tertiary Fort Union Group). The Bullion Creek Formation consists of an interbedded sequence of silty sandstone, silty claystone, and thin discontinuous lignite stringers ("upper zone") underlain by a relatively extensive lignite unit that varies from 4 to $7 \mathrm{ft}$ ( 1 to $2 \mathrm{~m}$ ) in thickness (middle "lignite zone") which in turn is underlain by an interbedded sequence similar to the upper zone ("lower zone").

Groundwater occurs under unconfined conditions in the upper zone, to confined conditions in the lower zone, with semi-confined conditions possibly existing in the lower part of the upper zone and in the lignite zone. Water levels range from 6 to $20 \mathrm{ft}(1.8$ to $6 \mathrm{~m})$ below the surface. The groundwater system is recharged directly by precipitation, and seepage from intermittent streams and standing surface water. Groundwater recharge to the lignite zone and the lower zone is influenced by downward leakage through the upper zones, as well as by subsurface underflow. There is no evidence of natural discharge of groundwater from the upper zone or the lignite zone to the land surface or surface water in the vicinity of the site.

Groundwater in the upper zone generally flows to the northeast and southwest, away from a local ridge. Groundwater in the lignite zone generally flows toward the southeast, and groundwater in the lower zone generally flows toward the east and southeast. The vertical hydraulic gradient beneath the Bowman site is downward toward the lignite zone. The average hydraulic conductivity calculated from aquifer pumping tests in monitor wells completed in the upper zone was $0.23 \mathrm{ft} / \mathrm{day}(8.1 \mathrm{x}$ $10^{-5} \mathrm{~cm} / \mathrm{s}$ ). The average hydraulic conductivity calculated from aquifer pumping tests in monitor wells completed in the lignite zone was $10.21 \mathrm{ft} /$ day $\left(3.6 \times 10^{-3} \mathrm{~cm} / \mathrm{s}\right)$. The average hydraulic conductivity calculated from an aquifer pumping test in a monitor well completed in the lower zone was $0.15 \mathrm{ft} /$ day $\left(5.3 \times 10^{-5} \mathrm{~cm} / \mathrm{s}\right)$. The 
average linear groundwater velocity for the upper zone was $4.6 \times 10^{-3}$ feet/day $\left(1.6 \times 10^{-6} \mathrm{~cm} / \mathrm{second}\right)$, for the lignite zone was $0.20 \mathrm{tt} /$ day $\left(7.1 \times 10^{-5} \mathrm{~cm} / \mathrm{s}\right)$, and for the lower zone was $3.8 \times 10^{-3} \mathrm{ft} /$ day $\left(1.3 \times 10^{-6} \mathrm{~cm} / \mathrm{s}\right)$.

Background groundwater quality in the three hydrogeologic units has been determined by chemical analysis of water samples collected from monitor wells located upgradient from the site. Evaluation of water-quality data from background monitor wells completed in the upper zone shows that maximum background concentrations are below the MCLs. Data from monitor wells completed in the lignite zone show that maximum background concentrations are below the MCLs except for chromium and selenium. Data from monitor wells completed in the lower zone show that maximum background concentrations were below the MCLs.

Concentrations of contaminants in the soil pore fluid were analyzed from samples collected from five suction lysimeters. Average concentrations of cadmium, chromium, lead, molybdenum, selenium, and uranium exceeded the MCLS. Analytical results from the lysimeter samples were used as an estimate of the existing source concentrations of the contaminated materials.

Contaminants in groundwater, related to the uranium ashing activities, do not form a discrete plume in the upper zone downgradient from the designated site, but are concentrated in areas generally beneath and adjacent to the site. This is a result of the diffuse nature of the contaminant source related to the lignite ashing process. In the upper zone, concentrations of cadmium, chromium, lead, molybdenum, selenium, and uranium in groundwater exceeded the MCLs. Concentrations of nitrate exceeded the MCL in one monitor well (nitric acid was not used in the uranium processing activities at the Bowman site, and concentrations in groundwater are most likely a result of the application of fertilizer to adjacent cultivated lands and effluent from nearby septic tanks). The extent of groundwater contamination in the lignite zone is significantly less than groundwater contamination in the upper zone. This is a result of dilution by groundwater flowing through the more transmissive fractured lignite, and the relative reducing capacity of the lignite (which would tend to cause uranium and other constituents to precipitate out of solution). In the lower zone, the concentrations of all constituents were below the MCLs.

The only use of groundwater within the site vicinity is from two existing wells completed in the Bullion Creek aquifer system on a farm $500 \mathrm{ft}(152 \mathrm{~m})$ north of the disposal site. These wells supply stock and domestic water for a household, but are not used as a source of drinking water. The city of Bowman municipal water supply is derived from several wells within the city limits and southeast of town at depths in excess of $1000 \mathrm{ft}(300 \mathrm{~m})$. Alternative water supplies in the vicinity of the site are available from deeper aquifer systems underlying the Bullion Creek and Upper Ludlow aquifer system.

\subsection{SURFACE WATER}

This section provides a general description of the watersheds and surface water features that may impact the Belfield and Bowman sites. Additional descriptions of surface water conditions may be found in the Floodplains/Wetlands Assessment (Attachment 1). 


\subsubsection{Surface water features}

\section{Belfield site}

At the Belfield site, the North Branch of the Heart River, the only surface water feature in the immediate site vicinity, flows primarily during spring runoff and after heavy rainfall. For the remainder of the year, stagnant water ponds at low points in the channel, which is 10 to $15 \mathrm{ft}(3$ to $4.6 \mathrm{~m})$ below the general site elevation. Water in the site area either ponds on the site or drains to the river. The railroad tracks are an effective barrier to water entering the site area from the south.

\section{Bowman site}

The Bowman site is on a low drainage divide within the Spring Creek watershed. A broad, ephemeral stream west of the site area is the only surface water feature in the immediate area. Water from the eastern portion of the site tends to pond on either side of the unpaved county road that separates the two tracts of the site. Water from areas north of the railroad tracks is diverted away from the site area. Two culverts along US-12 divert water from the western portion of the site to low-lying areas where the ephemeral stream west of the site intersects the highway. On the eastern side of the drainage divide, water is diverted to a small ephemeral stream $0.5 \mathrm{mi}(0.8 \mathrm{~km})$ east of the site that joins Spring Creek, an intermittent stream, $1.5 \mathrm{mi}(2.4 \mathrm{~km})$ southeast of the site area.

\subsubsection{Flood potential}

\section{Belfield}

The 10.7-acre (4.3-ha) Belfield designated site is within the boundaries of the 100-and 500-year floodplain on the North Branch of the Heart River, except for a small area along the southwestern portion of the site (Figure 2.1 of Attachment 1) (FEMA, 1983). Estimates of expected peak flow rates for the North Branch of the Heart River in the immediate site vicinity were taken from a USGS analysis (Attachment 1). The estimated 100-year flood is $8000 \mathrm{ft}^{3} / \mathrm{s}\left(227 \mathrm{~m}^{3} / \mathrm{s}\right)$. The estimated probable maximum flood (PMF) of $48,000 \mathrm{ft}^{3} / \mathrm{s}\left(1359 \mathrm{~m}^{3} / \mathrm{s}\right)$ in the site area would overflow the banks of the North Branch of the Heart River and submerge the processing site.

\section{Bowman}

The Bowman site is on a low drainage divide within the Spring Creek watershed. A broad ephemeral stream west of the site area is the only surface water feature in the immediate area. This site is not subject to flooding.

\section{Borrow sites}

The Griffin borrow site, across US-12 from the Bowman site, is on the same low ridge as the Bowman processing site and at a slightly higher elevation. Water at the Griffin site drains in several directions. The site is not subject to flooding due to its elevation above the surrounding area. 


\subsubsection{Surface water quality}

\section{Belfield}

Limited water quality analyses are avallable on the water in the North Branch of the Heart River above and below the Belfield designated site. Water quality analyses of two surface water samples collected from the river $1 \mathrm{mi}(1.6 \mathrm{~km})$ southeast and downgradient from the site in 1987 indicate that the EPA and state drinking water standards were exceeded for cadmium, chromium, iron, manganese, lead, sulfate, and TDS (DOE, 1989). The presence of these elevated levels of contaminants is the result of naturally occurring conditions and is not the result of contamination being derived from the site. Surface waters may have been contaminated in the past, but currently the downstream surface water quality does not appear to be contaminated from the sites. See Final RAP, Volume 1, pages 49 and 51 (DOE, 1990).

\section{Bowman}

Since the flow in Spring Creek is ephemeral, water quality sampling data are very limited for this area. Water quality analysis of one surface-water sample collected from a pond on Spring Creek $1 \mathrm{mi}(1.6 \mathrm{~km})$ south of the site indicates that the EPA and state drinking water standards are exceeded for cadmium, chromium, lead, molybdenum, sulfate and TDS (DOE, 1989). The presence of these elevated levels of contaminants is the result of naturally occurring conditions and is not the result of contamination being derived from the site. Surface waters may have been contaminated in the past, but currently the downstream surface water quality does not appear to be contaminated from the sites [see Final RAP, Volume 1, pages 49 and 51 (DOE, 1990)].

\subsection{FLORA AND FAUNA}

The Belfield and Bowman sites are in the Upper Missouri Basin and Broken Land physiographic region within the short-grass-wheatgrass-needlegrass plant association (Kuchler, 1975). Attachment 1, Floodplains/Wetlands Assessment, presents more details regarding the wooded draw habitat at the Belfield site and the wetland at the Bowman site. A detailed analysis of tiie potential for threatened and endangered (T\&E) species and other species of concern appears in a biological assessment (DOE, n.d.). The results in that report are surnmarized in this EA. This biological assessment also provides more detail regarrsing nonthreatened and endangered species that occur at the sites.

\subsubsection{Belfield site}

Three grass-dominated and one wooded community types were identified at the Belfield site. The first plant community type is dominated by nonnative grass species along the easement between the Burlington Northern Railroad and a county road just south of the railroad. This area is dominated by smooth brome along with a variety of herbaceous plants (DOE, 1983a). The second grass-dominated plant community is also grass-dominated and occurs adjacent to the woody vegetation along the Heart River. This area is actively grazed and has a plant species composition similar to the nonnative grassland plant community; crested wheatgrass is also common along with 
smooth brome (DOE, 1983a). The third grass-dominated plant community type is a cultivated hay field south of the county road.

The fourth plant community is a wooded draw that occurs along the Heart River and is the Fraxinus pennsylvania/Ulmus americana/Prunus virginianus type according to Girard et al. (1984). The vegetation in the wooded draw consists of deciduous trees and shrubs that grow in a narrow band along the river. The dominant tree species are American elm and green ash. Chokecherry is an abundant tall shrub in the understory while the most abundant common low-growing shrub is snowberry. The ground cover is dominated by grass; various herbaceous plant species also were observed. Emergent aquatic vegetation grows in narrow bands along the river with various species of rushes, sedges, bulrushes, and arrowhead being commonly observed. This wooded draw is a U.S. Army Corp of Engineers (USACE) jurisdictional wetland (Disbro, 1986; Zschomler, 1986) and is also designated as unique habitat in North Dakota by the U.S. Fish and Wildlife Service (FWS) (Collins, 1987).

Detailed studies of reptiles and amphibians in the vicinity of the Belfield site have not been conducted.

Thirty-six species of breeding birds were observed in the wooded draw. A total of 51 species of birds were observed during surveys at the site (TAC, 1992, 1986, 1985) including nesting waterfowl along the Heart River.

Detailed field studies of wild mammals were not conducted; however, a total of 32 species of wild mammals may occur at the Belfield site area.

\subsubsection{Bowman site}

The Bowman site area is dominated by gently rolling hills vegetated by species typical of the short-yrass prairie habitat. Some of the area is used for dryland farming; wooded areas in the form of shelter belts and small wetlands are scattered throughout the area.

Five plant community types were identified at the Bowman site and associated contaminated areas (TAC, 1986; 1985). Three plant communities were grassdominated.

The fourth plant community type is an ephemeral wetland west of the designated site area along an unnamed tributary to Spring Creek. This area is not mowed or grazed and is dominated by cordgrass; blue-grass, sedges, and rushes were also observed. This is a USACE-jurisdictional wetlands area (Disbro, 1986; Zschomler, 1986).

The only woody plant community is a shelterbelt associated with the farm complex just north of the site. Elm is the dominant tree species and some are up to $55 \mathrm{ft}$ $(17 \mathrm{~m})$ tall. Smaller trees growing in this area were Russian olive and juniper. The ground cover is a dense growth of grass and herbs in more open areas, while the ground cover is fairly sparse in areas with a closed canopy. The major flowering species in this area in June 1986 was dame's rocket (TAC, 1986).

Very few species of amphibians or reptiles were recorded at the Bowman site. 
A total of 48 species of birds were recorded in the vicinity of the Bowman site (TAC, 1992, 1987, 1986) Sixteen species of birds were recorded in the shelterbelt; the western kingbird and mourning dove were the most common species observed (TAC, 1987, 1986).

The sharp-tailed grouse was the only upland game bird observed near the site (TAC, 1987). The short-grass prairie habitat is optimum habitat for this species (Harrington and Assoclates, 1984).

Five species of duck were observed at or near the site. Waterfowl were not observed within the boundary of the contaminated area.

Eight species of birds of prey were observed in the site area. The great-horned owl and kestrel were observed in the shelterbelt and may nest there although, no nests were observed. The turkey vulture, golden eagle, northern harrier, Swainsons hawk, and red-tailed hawk were observed flying in the area; no evidence of these species nesting in the area was obtained. The ferruginous hawk was observed near the site and two inactive nests also were observed in 1986 and 1987; these nests were not active in 1992 (TAC, 1992, 1987, 1986).

A total of 32 species of mammals may occur at the Bowman site; 12 species were observed at or near the site. White-tailed deer were the most abundant big game species recorded on the site. A few pronghorn antelope and mule deer were observed in the rolling hills $0.75 \mathrm{mi}(1.26 \mathrm{~km})$ north of the site (TAC, 1992, 1987, 1986). These species may use the site area to a limited extent.

\subsubsection{Borrow sites}

The Griffin borrow site is immediately south of the Bowman site. A brief ground reconnaissance survey of this site was conducted in June of 1987 (TAC, 1987). The borrow site is in grazed short-grass prairie habitat and cultivated fields. Grass was the dominant ground cover in the short-grass prairie habitat and common flowering plants observed were yarrow, yellow salsity, and alfalfa; no woody plants were observed. Additional plant species at this site are expected to be similar to those observed in the native grassland habitat at the Bowman site. Wildlife use of this site would be similar to the Bowman site.

\subsubsection{Threatened or endangered species and other species of concern}

The determination of T\&E species and other species of concern that may occur at the Belfield or Bowman sites was accomplished through consultation with the FWS and the North Dakota Game and Fish Department. The state indicated that no state-listed plant or animal species occur near the two sites (Henegar, 1985). Informal consultation with the FWS occurred in 1986, 1989, and 1992 (Bowman, 1986; Sapa, 1992, 1989). Consultation letters received from the FWS are attached to this EA (Attachment 2). Based on the letter received from FWS in 1992 (Sapa, 1992), five endangered species have the potential to occur at the sites. A detailed analysis of T\&E species appears in a biological assessment (DOE, n.d.) which is summarized below. 
The bald eagle occurs in North Dakota as a migrant; however, wintering population occurs, principally along the Missourl River and one nesting pair occur's in the state. An occasional bald eagle may occur at the sites during migration, but the eagle's (Dryer, 1992) occurrence is expected to be sporadic since no preferred habltat associated with large bodles of water occurs near the sites (Harrington and Associates, 1984).

The peregrine falcon has not been recorded as a breeding species in North Dakota since 1954. An occasional migrant may occur near the sites; however, this may be very sporadic since stop-over areas during migration consist of river bottoms that have an abundance of avian prey species (FWS, 1982).

The whooping crane occurs during migration in North Dakota. Occasional individuals stray west of the river during migration, and an occasional migrant whooping crane may occur in the wetland areas near the Belfleld and Bowman sites.

The black-footed ferret is not known to occur in North Dakota. However, this species is closely associated with the prairie dog and all prairie dog towns are considered potential black-footed ferret habitat (Hillman and Clark, 1980). Observations at the Belfield and Bowman sites and the proposed Griffin borrow site indicate that the prairie dog does not occur at any of these sites (TAC, 1992, 1987, 1986, 1985).

The American burying beetle occurs in the Black Hills of South Dakota. This species would not be expected to occur near the identified commercial rock quarry site in South Dakota. (Dryer, 1992)

Consultation with the FWS indicates that five candidate species may occur near the sites.

The regal fritillary butterfly occurs in southern North Dakota in undisturbed native mid grass to tall grass prairie habitat (Royer and Marrone, 1992). Royer and Marrone estimate that at least 1000 acres ( $405 \mathrm{ha}$ ) of such habitat is required to maintain a viable population of this species. This type of habitat does not occur at or near the Belfield and Bowman sites and, therefore, the occurrence of this species at these sites is very unlikely.

The Ferruginous hawk and its nests were observed near the Bowman designated site in 1986 and 1987 (TAC, 1987, 1986). In July, 1992, these nests had disappeared and no new nests were observed in the site area and this species does not presently nest at or near the Bowman site.

The Baird's sparrow occurs in central and western North Dakota (FWS, 1992a) and prefers to nest in undisturbed or lightly disturbed prairie habitat (De Smet and Miller, 1989). This species has the potential to occur in the area of the Bowman site. However, the habitat at or near this site is crop land or heavily grazed prairie grasslands, which would not support a nesting population of this species. In addition, nesting bird surveys in 1986, 1987, and 1992 did not result in the observation of this species. Therefore, a nesting population of the Baird's sparrow does not occur at or near the Bowman site. 
The loggerheaded shrike nests throughout North Dakota and nests in wooded draws and shelterbelts (FWS, 1992b). This specles was recorded from near the Bowman site in 1986 (TAC, 1986) and has the potential to nest in the shelterbelt near this site and within the wooded draw at the Belfield site.

Originally, the swift fox occurred throughout the prairie habitat of North Dakota, but it is now very rare in North Dakota; the last confirmied observation was in 1976 (Harrington and Associates, 1984; McKenna and Seabloom, 1979). This species was not observed at the Belfield and Bowman sites during site-specific surveys (TAC, 1987, 1986; DOE, 1983a,b) or during intensive field studies in western North Dakota (Harrington and Assoclates, 1984; Seabloom et al., 1978).

\subsection{LAND USE}

The Belfield and Bowman UMTRA sites are located in Stark and Bowman countles, respectively, in southwestern North Dakota. The majority of the land in each county is privately owned and used for agriculture.

The Belfield designated site and the land around it are privately owned. The site contains two buildings. One building was formerly used for honey processing, and the other building is presently leased to a drilling mud company, and is used for miscellaneous storage (Huschka, 1992). The site is bordered on the north by the North Branch of the Heart River and on the south by the Burlington Northern Railroad. Land uses in the site area include a maintenance yard for the state highway department and liquid petroleum gas tanks maintained by an agricultural cooperative. The town of Belfield is within $0.5 \mathrm{mi}(0.8 \mathrm{~km})$ of the designated site. The surrounding area is used for agriculture.

The Bowman designated site is $7 \mathrm{mi}(11 \mathrm{~km})$ northwest of the town of Bowman and immediately north of US-12. The designated site and the surrounding land are privately owned. The site is bordered on the north by the Burlington Northern Railroad and bordered on the south by US-12. The designated site and land immediately south of the site is not under cultivation. There is a residence approximately $500 \mathrm{H}(152 \mathrm{~m})$ north of the designated site. The surrounding land has been farmed for generations. The primary agricultural uses include dryland farming for wheat or small grains and raising cattle or sheep.

There are no prime farmlands as defined by the Farmland Protection Policy Act of 1981 (7 CFR 658) present in affected areas.

The Gritfin and Bowman borrow sites are on land privately owned; part of the Griffin borrow site area is cultivated. The Bowman borrow site is located in an area that is leased for sand and gravel extraction.

\subsection{CULTURAL RESOURCES}

The Belfield and Bowman designated sites and Griffin borrow site were evaluated for the presence of cultural resources in 1987 and 1988. The Bowman borrow site location has not been evaluated for the presence of cultural resources. 
Three historic sites and four prehistoric isolated artifacts were found in the Belfield site area. Two of the three historic sites appear to be north of the Heart River and therefore out of the designated site area. None of the three sites have been characterized as significant or eligible for listing on the National Register of Historic Places. Two of the four isolated artifacts have a high potential for being significant. Additional subsurface archaeological testing is necessary to verify the presence or absence of additional cultural resources in the area. No clearance from the State Historical Soclety has been obtained as yet for any of these finds (UNDAR-WEST, 1988 and 1987).

Inventory of the Bowman site resulted in identifying 23 historical structures, which Included standing and razed structures. These structures are thought to be related to the former townsite of Griffin. The town of Griffin was founded in 1907 as Atkinsori; the name was subsequently changed to Griffin in 1908. By the 1920s, the town consisted of 50 people and had a post office, church, general store, grain elevator, hotel, lumber comipany, and school. By 1930, the post office was removed and the town subsequently abandoned. The results of the survey evaluation was that a qualifled historian should further assess the significance of the occupational history and ownership of the town site (UNDAR-WEST, 1988).

The Griffin borrow site was resurveyed in 1988. A previously recorded historic site was reevaluated as insignificant. Three prehistoric isolated artifacts were found and evaluated as insignificant and not diagnostic; therefore, subsurface testing was not warranted. The recommendation was that no further work would be necessary at the Griffin site (UNDAR-WEST, 1988).

\subsection{SOCIOECONOMIC CHARACTERISTICS}

\subsubsection{Population and housing}

The towns of Belfield and Bowman were severely affected by the declines in the oil industry that began in 1982. As can be seen from the population table (Table 3.3), the population of Belfield decreased by approximately 50 percent between 1982 and 1990. The present population is composed of people that own land and farm or own a small business in the area. Area towns are small and have populations of between several hundred and several thousand.

The total number of vacant housing units in Stark and Bowman counties is unavailable. However, due to the population shifts resulting from unemployment related to the oil industry, it is anticlpated that rental units, including trailers, are available in the general area (Eiseman, 1992; Woodley, 1992.).

\subsubsection{Employment}

Mining and agriculture have historically provided the employment base for the Belfleld and Bowman areas. Employment opportunities in the area today, however, are related to agriculture and to businesses that provide local services (e.g., gas station, restaurant). The 1991 labor forces for Stark and Bowman counties were reported as 11,451 and 1,980, respectively. The unemployment rate for Stark County averaged 
Table 3.3 Summary of population for Stark and Bowman Countles, North Dakota for the perlod 1980-1992

\begin{tabular}{lcccc}
\hline \multicolumn{1}{c}{ Place } & 1980 Census & 1982 & 1990 Census & 1992 est. \\
\hline Stark County & 23,697 & 28,107 & 22,832 & 22,589 \\
Dickinson & 15,224 & 19,351 & 16,097 & N/A \\
Belfield & 1,274 & 1,757 & 887 & N/A \\
Bowman County & 4,229 & 4,314 & 3,596 & 3,537 \\
Bowman & 2,071 & 2,068 & 1,741 & N/A \\
\hline
\end{tabular}

Ref. Hogue, 1992.

5 percent in 1991 and likely reflects unemployment occurring in Dickinson, North Dakota. Bowman County has a lower unemployment rate (3.1 percent) than Stark County, which is likely due to the more rural nature of the area. Employment levels in this part of North Dakota have stabilized since the decline that started in 1982. The loss of oil industry-related jobs in the early 1980 s resulted in workers leaving the area to pursue employment opportunitles in other areas.

According to the Dickinson job service office, which covers an eight county area, there are about 170 workers that are qualified to drive a semi-trailer truck that were registered for work in 1992. In the same area, there were 120 heavy equipment operators that were registered for work. Training for tractor semi-traller truck driving is available at Dickinson State University in Dickinson, North Dakota (Lisko, 1992).

\subsubsection{Community services}

Dickinson, which is $19 \mathrm{mi}(31 \mathrm{~km})$ east of Belfield, is considered the trade center for Stark, Slope, and Bowman Counties. Bowman, however, is considered a mini-trade center for the area as well (Hogue, 1992). The eight western countles of Adams, Billings, Golden Valley, Hettinger, Dunn, Slope, Stark, and Bowman are administered through the Roosevelt-Custer Regional Council, which provides planning and technical assistance to communities and the counties. The Council consists of 21 members and an executive director and meets on a monthly basis. The towns of Belfield and Bowman each have a mayor. Both towns report a surplus in infrastructure related to population declines. School enrollment is under capacity. Emergency services are avallable, although both county staffs are small. Emergency medical care is avallable through the Sheriff's department for both Stark and Bowman Counties. There is a fullservice, 129-bed capacity hospital in Dickinson as well as a full-service 36-bed capacity hospital in Bowman with airlift capability to Bismarck, North Dakota. The hospltal in Bowman has an average bed use of 16 percent (Paulson, 1992). Belfield does not 
have a hospital but does have a clinic that is open one day per week for minor problems.

\subsection{TRANSPORTATION}

\subsubsection{Roads}

US-85 and US-12 would be used to transport the contaminated materials from the Belfield site to the Bowman disposal site. These Federal highways are two-lane, paved, undivided rural principal arterials. US- 85 is the north-south route that provides access to US.12 in Bowman. US. 12 provides east-west access between the clty of Bowman, the Bowman disposal site, the Griffin borrow site, and the Bowman borrow site (See Figure 1-1). All trucks hauling the contaminated materials from the Belfield site would need to go through downtown Bowman.

Based on the most current information, which was collected in 1988, US-85 just south of Belfield was estimated to have an average dally traftic (ADT) volume of 1050 vehicles. In Bowman, US.85 had an ADT of 1000 vehicles. Just south of the Bowman site on US-12, the ADT was 800 vehicles. Truck trafflc comprises between 10 and 20 percent of the current ADT on these roadways (Steinwand, 1992). The ADT reflects all vehicles passing a specific point and would therefore include traftic going in all directions.

Both highways are at a Level of Service $A$ and can sustain ADT volumes of up to 10,000 vehicles of all types. The Level of Service ratings refer to the amount of congestion occurring on the highway. Level of Service A means that there is currently no congestion (Johnson, 1987). Current usage is below road-carrying capacity.

County roads would be used for hauling borrow materials from the Bowman borrow site. The degree of use occurring on county roads is unknown. There are no offlicial road designations for area county roads and use is local. It is likely that existing use does not exceed 100 vehicles per day.

\subsubsection{Railroads}

As shown in Figure 2.1, the nearest transfer point for trains needing to travel east is at Terry, Montana. Terry has no scheduled train transfers and generally transfers cars within a 2. to 3 day period of arrival. There are no other convenient transfer points east of Bowman.

The Burlington Northern Rallroad has lines that run east-west through Belfleld and Bowman. The northern most line forms the southern boundary of the Belfield designated site. This line carries between 15 and 24 trains per cay. The trains are generally more than $1 \mathrm{mi}(1.6 \mathrm{~km})$ long and travel at speeds of between 15 and $50 \mathrm{mi} / \mathrm{hr}$ (24 and $80 \mathrm{~km} / \mathrm{hour}$ ). In Belfield, there is a rallroad overpass on US-85.

The rail line through Bowman carries two unit trains per day. West of Bowman, rallroad crossings are signed and occur every $2.5 \mathrm{mi}$ (4 km) (Kincaid, 1992). 


\subsection{NOISE}

No nolse surveys have been recently conducted in the areas of the Belfield and Bowman sites. Noise levels at the Belfleld site would likely be higher than at the Bowman site due to the existing commerclal uses within the area. However, it is anticlpated that amblent nolse levels in both areas are low due to the rural nature of the area. 


\subsection{ENVIRONMENTAL IMPACTS}

\subsection{INTRODUCTION}

The environmental impacts presented in this section are based on conservative assumptions and impact assessment procedures and thereby represent a realistic upper limit on the severity of the impacts that may occur. The actual impacts that may occur would likely be less severe than those identifled here. All impact assessments are based upon the following assumptions: the remedial action would take approximately 7 months to complete, with an average work week of five 8-hour days; the first 4 months would involve excavation of contaminated materials from the Belfield and Bowman sites, and stabilization of the materials in a pile at the Bowman site. This 4-month period includes 2 months for excavating the Belfield site and hauling materials to the Bowman site. After the contaminated materials are stabllized in a pile, they would be covered with a combination of radon barrler and erosion protection materials, as described in Section 2.2.

For the purposes of evaluating the impacts associated with the activities at these borrow sites, it was assumed that the reclamation material would come from an area no farther than $20 \mathrm{mi}(32 \mathrm{~km})$ from the Belfield site and that the scoria source areas would not exceed a maximum distance of $5 \mathrm{mi}(8 \mathrm{~km})$ from each designated site. The quantities of material, equipment, and labor required for these borrow operations were estimated to provide a realistic assessment of the impacts associated with the proposed action; a maximum of 5 acres ( $2 \mathrm{ha}$ ) would be required for borrow activities at each source area (DOE, 1989).

The borrow sites included in this EA were selected as the sources of necessary borrow materials for the conceptual design and impact analysis purposes. The materials at these sites meet the UMTRA Project physical design criteria requirements. The borrow sites that would actually be used for the remedial action would be selected during the final design phase. The impacts identified for the borrow sites included in this EA are conservative and represent a realistic upper limit on the severity of the impacts that may occur.

The proposed action also would require the expenditure of fuel for equipment and on-site operations, and water for compaction of the disposal cell solls, washdown of haul trucks, dust control, personal consumption, and shower and laundry facilities. Fuel would be purchased from a commercial source(s) and would be stored at the sites in tanks. Water resources are locally available at both sites and the remedial action requirements would not affect existing local use levels.

The railroad transportation option would require the use of specially designed containers that are currently in use at the Grand Junction, Colorado UMTRA site. Each container would hold an estimated volume of $31 \mathrm{yd}^{3}\left(24 \mathrm{~m}^{3}\right)$ of contaminated materlals; the large size of the containers would require that only two containers would fit on a train car. To load and unload the containers onto the train cars, siding would need to be constructed at the Belfield and Bowman train sites. An estimated 9.5 unit train trips would be required to transport all of the Belfield contaminated materials to the Bowman site. 
The rallroad option would require fewer workers than would be needed for the proposed action; therefore, the economic benefits assoclated with project employment would be less for the railroad option. Other impacts would be similar to those described for the truck transportation proposed action. Although actual impacts would be similar for the truck and rall transportation options, the residents of Terry, Montana, may have concern over the presence of trains that are carrying uranium mill tailings that are up to $1 \mathrm{mi}(1.6 \mathrm{~km})$ in length left on a siding for up to three days.

\subsubsection{The no action alternative}

The no action alternative would not involve any remedial action and therefore would not affect most of the environmental resources described in Section 3.0, such as transportation, flora and fauna, noise. Other environmental resources (e.g., alr quality) may be affected only slightly by no action.

This alternative would result in the cor tinued dispersion of the ash by wind and water erosion. Contaminants would continue to leach out of the soils and migrate into the groundwater in the uppermost aquifer. Source concentrations of hazardous constituents would decrease over time, and contaminants in groundwater in the uppermost aquifer would gradually be attenuated and diluted to the extent that any potentially adverse effects on human health and the environment would no longer be of concern.

Continued erosion and possible use of the ash may cause radiological contamination of other areas and could result in greater public health impacts than those calculated for the proposed action.

At the Belfield and Bowman sites, the general population may be exposed to radon decay products and airborne radioactive particles from the ash-contaminated solls. Currently there are no effective barriers to prevent continued dispersion and unauthorized removal and use of these contaminated soils, thereby increasing the general population's exposure to radon decay products, gamma radiation, and radioactive particles. The population's exposure to the current levels of radiation would continue until the remedial action begins. If no action is taken, an excess health effect of 1.3 has been predicted compared to the 0.15 excess health effect incurred 1000 years atter remedial action.

Finally, selection of the no action alternative would not be consistent with the intent of Congress in UMTRCA and would not result in compllance with the EPA standards.

\subsection{MINERAL RESOURCES}

Disposal at the Bowman site would likely preclude future development of any mineral resources beneath the Bowman disposal site. The UMTRCA requires that mineral rights for the disposal site be transferred with the permanent disposal site to the Federal Government. The UMTRCA also authorizes the Secretary of the Interior, with the concurrence of the Secretary of Energy and the NRC, to dispose "of any subsurface mineral rights by sale or lease ... if the Secretary of the Interlor takes such action as the commission deems necessary pursuant to a license issued by the 
Commission to ensure that the residual radioactive materials will not be disturbed by reason of any activity carried on following such disposition." Any recovery of mineral, oil, or gas resources from beneath the disposal site would be governed by license conditions to prevent any disturbance of the disposal cell. However, if the costs of avoiding disturbance of the disposal cell were too high, resource recovery would be precluded.

\subsection{RADIATION}

\subsubsection{Radiation exposure pathways}

There are four principal pathways through which individuals could be exposed to radiation during the remedial action and for which fatal cancer risks have been calculated 1) inhalation of radon decay products, primarily imparting radiation doses to the lung; 2 ) direct exposure to gamma radiation from the contaminated materials, or during transport through the local communities, giving radiation doses to the entire body; 3) inhalation of airborne radioactive particles, causing internal doses from alpha, beta, and gamma radiations; and 4) ingestion of food or water contaminated by radioactive materials from the sites, resulting in internal doses of radiation.

The risk from the ingestion of contaminated drinking water has been calculated in assessments for other UMTRA Project sites (DOE, 1992, 1985b, 1984b, 1983c). Results of these conservative assessments show that the health risks (fatal cancers) from ingestion of food or water contaminated by radioactive materials is very minor compared with exposures to radon decay products, gamma radiation, and radioactive particles, and is not included in this analysis.

Radon (Rn-222), an inert gas (i.e., does not react chemically with other elements) that emits alpha radiation during its radioactive decay, is produced from the radioactive decay of radium-226 (Ra-226) in the uranium-238 (U-238) decay series. As a gas, radon can diffuse through the contaminated materials and into the atmosphere, where it may be transported by atmospheric winds over a large area. In the atmosphere, radon decays into its solid decay products, which attach to airborne dust particles and can be inhaled by humans. These dust particles, with the radon decay products attached, may adhere to the lining of the lungs; when the radon decay products decay further, alpha radiation is released directly into the lungs.

Gamma radiation, also emitted by many members of the $U-238$ decay series, behaves independently of atmospheric conditions and travels in a straight line until it interacts with matter. Gamma radiation emitted from contaminated materials delivers an external exposure to the whole body. Exposure to gamma radiation may cause somatic health effects (manifested in the exposed individual), as well as genetic health effects (manifested in the descendants of the exposed individual). This analysis of excess health effects (health risks) reflects only somatic health risks.

Airborne radioactive particles are particles of contaminated soils containing radioactivity that have been suspended in the air. The smaller particles can be transported by wind and may disperse over a large area, similar to radon gas. The particles may then be inhaled by humans, and deliver internal doses from alpha, beta, and gamma radiation to different parts of the body. 
During remedial action, the radon decay product and airborne radioactive particle exposures to the general population and remedial action workers would increase as the contaminated materials are disturbed. Remedial action workers also would be exposed to direct gamma radiation during remedial action.

When the remedial action is completed, the contaminated materials would be properly stabilized in a permanent disposal cell at the Bowman site. There would be no further exposure to radioactive particles and gamma radiation levels would be reduced to within background. The earthen infiltration/radon barrier was designed to reduce the release of radon to 20 picocuries/meter squared per second $\left(\mathrm{pCi} / \mathrm{m}^{2} \mathrm{~s}\right)[0.74$ becquerels/meter squared per second $\left.\left(\mathrm{Bq} / \mathrm{m}^{2} \mathrm{~s}\right)\right]$ or less in accordance with the EPA standards.

\subsubsection{Short-term health risks}

The short-term health risks (those incurred during the remedial action) to the population are determined, in part, by the specific exposure pathway. For the general population, inhalation of radon decay products would be the exposure pathway of primary concern. Under existing conditions at both sites, large amounts of radon are being continually released to the atmosphere. These releases would increase only slightly, and temporarily, during remedial action. Inhalation of radioactive airborne particles would be of secondary importance. Direct exposure to gamma radiation would be the least significant pathway. Gamma radiation levels are almost at background levels for most of the surrounding areas at both sites, and are no more than double the background level at the residence $500 \mathrm{ft}(152 \mathrm{~m})$ north of the Bowman site.

Health risks to the general population during remedial action are principally dependent on the volume of contaminated materials to be moved and the number of people who live nearby. However, these estimated fatal cancer risks are very small in comparison to the natural incidence of cancer. For example, the proposed action would result in a total excess health effect of $880 \times 10^{-6}$ foi the general population during the remedial action, based on the present population distribution in the vicinity of the Belfield and Bowman sites (DOE, 1989). This is a 0.00002 percent chance per individual (based on a total exposed population of 3604 people) of contracting a fatal cancer due to radiation from the ashing sites, or about two chances in 10 million. In the United States, an individual has a 19 percent, or one in five, lifetime chance of contracting a fatal cancer (NAS, 1990). This would mean that of 3604 people, approximately 685 would be expected to die of cancer induced from causes other than radiation exposure from the two ashing sites.

Since the remedial action workers would be in close proximity to the contaminated materials, external gamma radiation emitted from these materials would be the dominant source of exposure. Inhalation of radioactive particles would be of secondary importance. The inhalation of radon decay products would be the least significant exposure pathway affecting the remedial action workers.

For both short-term and long-term health risks, the risks to the general population are not uniformly distributed. People who live near the ashing sites would generally be at greater risk than those living farther away. 


\section{4.3.3 Long-term health risks}

As stated previously, there would be no direct exposure to gamma radiation or airborne radioactive particles originating from the contaminated soils after remedial action. Radon releases would be no greater than the $20 \mathrm{pCi} / \mathrm{m}^{2} \mathrm{~s}\left(0.74 \mathrm{~Bq} / \mathrm{m}^{2} \mathrm{~s}\right)$ allowed by the EPA standard. These releases would result in very few annual health risks for persons living in the area of the permanent disposal site.

In the 1000 years following the remedial action, the total cumulative health effect is estimated to be $\mathbf{0 . 1 5}$, or less than one, at both sites. This estimate reflects a stable population; total health risks would increase if the nearby population increased. The 0.15 excess health effect incurred after 1000 years may be compared with 1.3 excess health effects predicted for the same period if no action is taken (DOE, 1989).

\section{$4 \quad 4.4$ GROUNDWATER}

The long-term groundwater quality impacts resulting from the proposed remedial action are summarized in this section.

The proposed remedial action for the Belfield and Bowman ashing sites involves relocating contaminated materials from the Belfield site to the Bowman site, and consolidating and co-disposing of these contaminated materials in a disposal cell at the Bowman site. Removal of the contaminated materials from the Belfield site would eliminate the source of contamination that could potentially affect groundwater. The disposal cell at the Bowman site would have a low-permeability cover designed to reduce the rate of infiltration of precipitation and minimize the potential for groundwater contamination. Design features in conjunction with existing hydrogeologic conditions at the Bowman disposal site would provide compliance with the proposed EPA groundwater standards, and would ensure sufficient protection of human health and the environment. Following removal of contaminated materials from the Belfield site, and containment of all contaminated materials in the disposal cell at the Bowman site, natural flushing would continue in the uppermost aquifers at both sites, resulting in an improvement in groundwater quality over time.

During the remedial action, groundwater would be monitored at the Belfield and Bowman sites to assess potential impacts of construction on groundwater quality beneath and downgradient from the sites. If the analytical results of groundwater sampling show statistically significant increases in constituents of concern, the situation would be assessed and appropriate action would be implemented at that time.

Groundwater use in the vicinity of the Belfield site should not be impacted by the proposed remedial action. Shallow groundwater in the vicinity of the site is used for stock watering and some domestic purposes, but not for drinking water supplies. The city of Belfield municpal water supply is derived from several wells within the city limits, at depths in excess of $1000 \mathrm{ft}$. $(300 \mathrm{~m})$. The wells are located at least $1000 \mathrm{ft}$ $(300 \mathrm{~m})$ upgradient from the site.

Groundwater use in the vicinity of the Bowman site should not be impacted by the proposed remedial action. Shallow groundwater in the vicinity of the site is used for 
stock watering and some domestic purposes but not for drinking water supplies. The city of Belfield municipal water supply is derived from several wells within the city limits, at depths in excess of $1000 \mathrm{ft}(300 \mathrm{~m})$. The wells are located at least $1000 \mathrm{ft}$ $(300 \mathrm{~m})$ upgradient from the site.

Groundwater use in the vicinity of the Bowman site should not be impacted by the proposed remedial action. Groundwater in the shallow aquifers is not considered a significant resource because of marginal water quality (associated with the nature of the sediments and the presence of mineralized zones) and limited yield from the fine-grained sediments. The only use of shallow groundwater in the vicinity of the site is from two farm wells that supply stock and domestic water for a household, but are not used as a source of drinking water. The city of Bowman municipal water supply is derived from several wells within the city limits and southeast of town at depths in excess of $1000 \mathrm{ft}(300 \mathrm{~m})$. Although these municipal wells are downgradient from the designated site, no impact from the contamination has been observed or is anticipated because the wells are approximately $7 \mathrm{mi}(11 \mathrm{~km})$ from the site and produce groundwater from much lower aquifer systems than those at the site.

\subsection{SURFACE WATER}

The proposed engineering design for the Belfield and Bowman sites and borrow areas includes temporary drainage ditches, erosion controls, and wastewater retention ponds (for evaporation of contaminated water) to prevent contaminated water from leaving the site areas. The design would be in accordance with Section 404 of the Clean Water Act and state discharge permit requirements.

All excavated areas would be backfilled, recontoured, and revegetated, as needed, to ensure positive drainage, thereby mitigating potentially adverse effects from surface erosion.

\subsection{FLORA AND FAUNA}

Remedial action would result in both direct (long- or short-term) and indirect (for the duration of the remedial action) impacts to the ecosystems at the two designated and borrow sites. Direct impacts would be the loss of wildlife habitat due to surface disturbances (e.g., cleanup of contaminated soils, upgrading of roads, and borrow activities), the destruction of less mobile wildlife such as small mammals and reptiles, and the displacement of larger mammals and birds from affected areas. In addition, displaced wildlife may be forced to compete with other resident wildlife for habitat or forced to inhabit marginal habitat, which could result in a reduced survivorship for the displaced wildlife. The severity and duration of these direct impacts would depend on the quantity and quality of the affected habitat and the type of reclamation of these affected areas. On a per unit area basis, direct impacts would be less severe in areas of low productivity (e.g., grassland habitat) and more severe in more productive areas (e.g., wooded areas).

During remedial action at the Belfield and Bowman sites and the Griffin borrow site, 139 acres (56 ha) consisting of 57 acres ( $23 \mathrm{ha}$ ) of nonnative grassland, 35 acres (14 ha) of short-grass prairie, 32 acres (13 ha) of agricultural fields, 4 acres (2 ha) of wooded draw, and 11 acres ( $4 \mathrm{ha}$ ) of highly disturbed land would be cleared. 
Approximately 2 acres $(0.8$ hectare) of the wosoded draw lie within the contaminated areas slated for excavation at Belfield site; however, the wooded draw would not be disturbed because supplemental standards would be applied to this area. The wooded draw is eligible for supplemental standards because the area lies outside the designated site boundary and has vicinity property status, Ra-226 concentrations are relatively low and the ecological damage would be high (see Attachment 1 for more details).

Reclamation of the cleared habitat would likely include recontouring and revegetation. Good stands of grassland habitat (introduced species or native species) may be reestablished in the cleared grassland habitat provided proper site preparation and planting methods are followed (Duebbert et al., 1981). It is expected that vertebrate species typical of grassland habitat in the site area would reinvade reclaimed areas within one or two years after the area was restored (Higgins et al., 1984; Hoag et al., 1984).

The wooded draw at the Belfield site would require restoration if supplemental standards cannot be applied and this area is cleared. Restoration of this plant community type would be more difficult than the grassland plant communities. The loss of this habitat would be long-term because it would take a number of years to reestablish the woody plant community along the Heart River. However, since only two acres would be cleared, the overall impact of the long-term loss of this plant community type is judged to be minimal.

Field surveys indicated that no T\&E species occur at the Belfield, Bowman, or Griffin sites (see DOE, n.d. for more detail). Surveys for prairie dog towns should be conducted at the restoration materials and scoria borrow sites when the exact locations of these borrow sites are identified. If prairle dogs occur at any or all of these sites, surveys for the black-footed ferret would be necessary.

The ferruginous hawk and loggerheaded shrike were the only Federal candidate species known to occur at the sites. Although the ferruginous hawk nested in the area of the Bowman site in 1986, no nest sites were observed in 1992 and it is unlikely that remedial action activities would impact this species. However, since the ferruginous hawk habitat occurs near the Bowman site, this species may renest near the site. Therefore, it is recommended that surveys for this species be conducted during the spring before the start of remedial action.

The loggerheaded shrike is known to occur near the Bowman site and potential nesting habitat for this species occurs in the wooded draw at the Belfield site and the shelterbelt at the Bowman site. These wooded areas would not be cleared because supplemental standards would be applied to the Heart River at the Belfield site and the shelterbelt at the Bowman site is not contaminated. For these reasons, remedial action activities are not expected to impact the loggerheaded shrike. 


\subsection{LAND USE}

The proposed action would require the temporary disturbance of an estimated 139 acres (56 ha) at the Belfield and Bowman disposal sites, the Griftin and Bowman borrow sites, and for construction of an access road to the Belfield site. There would be a permanent loss of use of 12.1 acres $(4.9 \mathrm{ha}$ ) for the Bowman final restricted disposal site. Approximately 3 acres (1 ha) of the 12.1 acres (4.9 ha) are within the designated site boundary and are not currently in use.

One of the two buildings at the Belfield site would be decontaminated and the other, currently vacant building, would be demolished as part of the remedial action. The two existing businesses would be relocated until decontamination of the buildings and removal of all hazardous materials from the designated site has been completed.

The Bowman site and surrounding contaminated area is not under cultivation. The permanent loss of 12.1 acres ( $4.9 \mathrm{ha}$ ) for the permanent disposal cell would not be considered a significant impact, since this acreage represents a small part of a much larger landholding. The owner would be compensated for the loss of the land.

An estimated 20 acres ( 8 ha) would be disturbed for borrow materials at the Griffin borrow site. Approximately 7 acres ( 3 ha) of this privately owned site are cultivated each summer; the remaining area is a rock outcrop that cannot be cultivated. When the remedial action is complete, the area would be reclaimed per stipulations of the landowner and the landowner would be compensated for the loss of current uses of the land.

Approximately 5 acres ( $2 \mathrm{ha}$ ) would be disturbed for borrow materials at the Bowman borrow site. This proposed borrow site is leased for sand and gravel operations and the proposed use of the materials would not constitute a new impact.

\subsection{CULTURAL RESOURCES}

Prior to any ground-disturbing activities, the DOE would perform cultural resource surveys at the Bowman borrow site if necessary, and collect additional data where warranted. Since the Bowman borrow site is located on an existing sand and gravel lease, cultural resource evaluation may not be necessary. Prior to the remedial action, the State Historic Preservation office would be contacted to ensure that all potentially disturbed areas have been appropriately evaluated. In the event that cultural resources were identified during the remedial action, all work would be stopped in the area of the find until proper evaluation was completed and the find either collected or sufficient data was retrieved.

\subsection{SOCIOECONOMIC CHARACTERISTICS}

The proposed action is estimated to require 73 workers. Due to the requirements of this construction project, workers would be primarily truck drivers and heavy equipment operators. Although both Belfield and Bowman are small rural towns, it is anticipated that the majority of the work force would be available in the region (see Section 3.11). Workers from outside of the area would likely commute to work during 
the remedial action. Historically, the UMTRA Project has hired an average of between 70 and 80 percent of all workers from within a commuting distance to the UMTRA work sites.

The in-migration of workers for the UMTRA Project would not affect existing housing supplies. In the past, the region has housed larger work forces during the oil industry boom and vacant housing continues to be available throughout the area.

The majority of the remedial action is scheduled for the summer months and would not result in disruption of area school systems.

Remedial action would have a direct and positive impact on local economies through wages paid to remedial action workers and expenditures for materials, supplies, and equipment. There may be additional, indirect positive benefits to the local economy as the money from these wages, and local purchases are recirculated throughout the local economies. Indirect expenditures would generate tax revenues that would be available for local and state governmental use. Direct purchases would not be subject to taxes because the Federal Government is exempt from paying taxes on expenditures for Federally funded projects.

The estimated construction cost of the proposed remedial action is $\$ 4.2$ million. This figure includes costs assoclated with subcontract labor, and purchases or rental of equipment, materials, and supplies. The amount that would directly benefit the communities of Belfield and Bowman is estimated to be $\$ 2.6$ million. Indirect revenues are estimated at $\$ 0.6$ million. The total estimated project-related revenues that would return to the local economy are $\$ 3.2$ million.

\subsection{TRANSPORTATION}

The heaviest use of area roads would occur during the 2-month period when the Belfield contaminated materials are transported to the Bowman site. An estimated 243 vehicle trips per day would be required to transport the contaminated materials to the disposal site. The UMTRA-related traffic would result in an estimated 24 percent increase in area traffic on US-85 and a 30 percent increase of traffic on US-12. This increase in truck traffic may be perceived as an impact by the residents of Bowman who live along US-85. However, the increase in existing traffic would be considerably below the Level of Service rating reported as 10,000 vehicles per day (see Section 3.12 of this EA) and would not be considered a significant impact resulting from the proposed action. The remainder of project road use would occur on county roads that currently receive light use.

\subsection{NOISE}

The remedial action would require the use of heavy equipment at the disposal site to properly consolidate and cover the contaminated materials. Due to the proximity of the adjacent residence to the disposal site $500 \mathrm{ft}(152 \mathrm{~m})$, noise would constitute a major impact to the residents from the proposed action. However, all project activities would be subject to state and Federal noise regulations. The DOE is evaluating a change in the orientation of the disposal pile such that the residents would not be in a direct line of sound from the pile. 


\subsection{MITIGATIVE MEASURES}

The following mitigative measures were incorporated into the design and approach for the proposed action to reduce the environmental impacts.

- Wastewater retention ponds would be constructed to prevent contaminated construction water and potentlally contaminated rain water from leaving the site area, causing erosion during runoff, or contributing to the existing contamination.

- All trucks used for transporting contaminated material to the disposal areas would be equipped with tight-fitting tailgates, and if needed, covered with tarpaulins to prevent leakage.

- To prevent off-site contamination during transportation of the contaminated materials, all trucks would be monitored and decontaminated, if necessary, prior to entering public roads; all trucks would be restricted to the designated access or haul roads.

- Water, chemical additives, and/or a combination of water-based surfactants and additives would be used on disturbed areas, unpaved haul roads, and on the tailings, when necessary, to inhibit dust emissions. Loads would be covered, if necessary, to prevent windblown dust during transport of tailings. All work would be stopped if fugitive dust emissions exceeded state or Federal air quality standards.

- Use of water for dust suppression would be controlled to limit soil infiltration of contaminated water.

- Monitor wells placed through the contaminated soils on-site would be decommissioned (grouted or removed) to prevent direct seepage of tailings fluids into the underlying aquifers. The monitor wells would be decommissioned in accordance with the DOE Wellhead Protection Program.

- Uncontaminated topsoil would be stockpiled separately at each location for later use in site restoration.

- All privately owned disturbed areas would be reclaimed per stipulations by the land owner. Reclamation may include revegetation with plants native to the area and restricting grazing use of the reclaimed area (e.g., fencing) until revegetation is established.

- A soil/vegetated cover is presently under consideration for incorporation into the design of the disposal cell that would lessen the visual intrusion on the landscape.

- Noise generated by construction activities would be mitigated by adhering to normal working hours per day for the 7-month remedial action period.

- The DOE would develop and implement a data recovery plan prior to any ground disturbance for any significant or potentially significant cultural or archaeological sites that may be impacted by remedial action activities. 
- Environmental monitoring is a requirement of the UMTRA Project during remedial action activities at both the sites. Monitoring stations would be strateglcally located offsite at each construction site to monitor alrborne particulates, radon, and environmental gamma radiation exposure. 


\subsection{CONSULTATION, COORDINATION, AND LIST OF PREPARERS}

\subsection{CONSULTATION AND COORDINATION}

The following state and Federal agencies have been instrumental in providing information and assessing UMTRA Project impacts on their resources.

North Dakota Geological Survey

Bismarck, North Dakota

David Brokke

North Dakota State Game and Fish Department

Bismarck, North Dakota

D. L. Henegar

Alex Doxbury

North Dakota State Department of Health and Consolidated Laboratories

Division of Environmental Engineering

Air Pollution Control Program

Bismarck, North Dakota

Steve Weber

North Dakota State Department of Health

Bismarck, North Dakota

Gene Christlanson

North Dakota State Department of Health

Division of Environmental Engineering

Bismarck, North Dakota

Dana Mount

North Dakota Department of Transportation

Bismarck, North Dakota

Kurt Johnson

U.S. Army Corps of Engineers

Omaha, Nebraska

Sam Disbro

U.S. Fish and Wildlife Service

Bismarck, North Dakota

Roger Collins

Mark Dryer

Stan Zscholmer

Allyn J. Sapa 
U.S. Fish and Wildilie Service

Grand Island, Nebraska

Davld Bowman

Dennis Buechler

U.S. Geological Survey, Bismarck District Offlice

Bismarck, North Dakota

Norm Hatfield

\subsection{LIST OF PREPARERS}

The engineering design, including transportation routes, was developed by MK-Ferguson Company, the Remedial Action Contractor (RAC) to the DOE.

This EA was prepared by the Jacobs Engineering Group, the Technical Assistance Contractor (TAC) to the DOE, based on the design provided by the RAC.

Numerous individuals assisted in the production of this EA. The following individuals provided key expertise and were instrumental in the analysis of the project.

Sandra Beranich: Cultural resources, land use, noise, socioeconomics, and transportation.

Charles Burt:

Flora and fauna, threatened and endangered specles, wetlands.

Robert Cornish,

Terry Kraus:

Radiation.

George Hartmann:

Conceptual design, flood analysis.

Richard J. Heydenburg: Hydrology.

Gerald Lindsey: Geology, solls.

Paul E. Martinez: NEPA coordinator.

Carmen Silva: Editing.

Llz Wagner: Graphics.

Clyde Yancey: Site Manager. 


\subsection{REFERENCES}

BFEC (Bendlx Fleld Engineering Corporation), 1986a. Badlologlc Characterization of the Bellield, North Dakota, Uranium Mill Taillings Remedial Action Site, GJ-49, prepared for the U.S. Department of Energy, UMTRA Project Office, Albuquerque Operations Office, Albuquerque, New Mexico.

BFEC (Bendix Field Engineering Corporation), 1986b. Radiologic Characterization of the Bowman, North Dakota. Uranium Mill Tallings Remedial Action Site, GJ.52, prepared for the U.S. Department of Energy, UMTRA Project Office, Albuquerque Operations Offlce, Albuquerque, New Mexico.

Bowman, D., 1986. U.S. Fish and Wildilife Service, Grand Island, Nebraska, personal communication with David Lechel, Manager of Environmental Services, Jacobs Engineering Group Inc., Albuquerque, New Mexico, dated February 4, 1986.

Collins, R., 1987. U.S. Fish and Wildlife Service, Bismarck, North Dakota, personal communication with C. H. Persson-Reeves, Environmental Services, Jacobs Engineering Group Inc., Albuquerque, New Mexico dated October 30, 1987.

DeSmet, K. D. and W. S. Miller, 1989. "Status Report on the Baird's Sparrow, Ammodramus bairdil," Committees on the Status of Endangered Wildifie in Canada, Ottawa, Ontario, Canada.

DOE (U.S. Department of Energy), n.d., in preparation. "Biological Assessment for the Inactive Uraniferous Lignite Ashing Sltes at Belfield and Bowman, North Dakota," UMTRA-DOE/AL_____ prepared by the U.S. Department of Energy, UMTRA Project Offlce, Albuquerque Operations Office, Albuquerque, New Mexico.

DOE (U.S. Department of Energy), 1992. Environmental Analysis and Data Report of Remedial Action at the Inactive Uraniferous Lignite Processing Sites of Belfield and Bowman, North Dakota, UMTRA-DOE/AL-150322.0000, prepared by the U.S. Department of Energy, UMTRA Project Office, Albuquerque Operations Office, Albuquerque, New Mexico.

DOE (U.S. Department of Energy), 1990, "Remedial Action Plan for Stabilization of the Inactive Uraniferous Liginite Processing Sites at Belfield/Bowman, North Dakota," UMTRA-DOE/AL-050522, prepared by the U.S. Department of Energy, UMTRA Project Office, Albuquerque Operations Office, Albuquerque, New Mexico.

DOE (U.S. Department of Energy), 1989. "Remedial Action Plan and Site Conceptual Design for Stabilization of the Inactive Uraniferous Lignite Processing Sites at Belfield and Bowman, North Dakota," UMTRA-DOE/AL-050522.0000, unpublished prelliminary final, prepared by the U.S. Department of Energy, UMTRA Project Office, Albuquerque Operations Office, Albuquerque, New Mexico. 
DOE (U.S. Department of Energy), 1988. "Supplemental Characterization of the Inactive Uraniferous Lignite Processing Sites at Belfield and Bowman, North Dakota," UMTRA. DOE/AL 400645.0000, prepared by the U.S. Department of Energy, UMTRA Project OHflce, Albuquerque Operations Office, Albuquerque, New Mexico.

DOE (U.S. Department of Energy), 1987. "Comparative Analysis of Disposal Site Alternatives Report for the UMTRA Project Belfield and Bowman, North Dakota, Processing Sites," prepared by the U.S. Department of Energy, UMTRA Project Offlce, Albuquerque Operations OHice, Albuquerque, New Mexico.

DOE (U.S. Department of Energy), 1985a. "Environmental Assessment of Remedial Action at the Riverton Uranium Mill Tallings Site, Riverton, Wyoming," unpublished data, DOE UMTRA Project Office, Albuquerque Operations Office, Albuquerque, New Mexico.

DOE (U.S. Department of Energy), 1985b. Environmental Assessment of Remedial Action at the Lakeview Uranlum Mill Tallings Site, Lakeview, Oregon, UMTRA-DOE/EA-0271, DOE UMTRA Project Office, Albuquerque Operations OHfice, Albuquerque, New Mexico.

DOE (U.S. Department of Energy), 1984a. Final Environmental Assessment of Remedial Actions at the Former Vitro Chemical Company Site, South Salt Lake, Salt Lake County, Uta., DOE/EIS-0099-F, DOE UMTRA Project Office, Albuquerque Operations Office, Albuquerque, New Mexico.

DOE (U.S. Department of Energy), 1984b. Final Environmental Impact Statement, Remedial Actions at the Former Vitro Chemical Company Site, South Salt Lake, Salt Lake County, Utah, DOE/EIS-0099-F, DOE UMTRA Project OHIce, Albuquerque Operations Office, Albuquerque, New Mexico.

DOE (U.S. Department of Energy), 1983a. "Environmental Assessment of Remedial Actions on the Uranium Residues at the Belfield Site, Stark County, North Dakota," unpublished report, DOE UMTRA Project Office, Albuquerque Operations Office, Albuquerque, New Mexico.

DOE (U.S. Department of Energy), 1983b. "Environmental Assessment of Remedial Actions on the Uranium Residues at the Bowman Site, Bowman County, North Dakota," unpublished report, DOE UMTRA Project Office, Albuquerque Operations Office, Albuquerque, New Mexico.

DOE (U.S. Department of Energy), 1983c. Final Environmental Impact Statement, Remedial Actions at the Former Vitro Rare Metals Plant Slte, Canonsburg, Washington County, Pennsylvania, DOE/EIS-0096-F, DOE UMTRA Project Offlce, Albuquerque Operations Otfice, Albuquerque, Now Mexico.

Disbro, S., 1986. U.S. Army Corps of Engineers, Omaha, Nebraska, personal communication with Charles Burt, Environmental Services, Jacobs Engineering Group Inc., Albuquerque, New Mexico, dated March 6, 1986.

Dryer, M., 1992. U.S. Fish and Wildlife Service, Bismarck, North Dakota, personal communication with Charles Burt, Environmental Service, Jacobs Engineering Group, Inc., Albuquerque, New Mexico, dated July 9, 1992. 
Duebbert et al. (H. F. Duebbert, E. T. Jacobson, K. F. Higgins, and E. B. Podoll), 1981.

"Establishment of Seeded Grasslands For Wildlife Habltat in the Prairle Pothole Reglon,"

U.S. Fish and Wildife Service, Special Scientific Report - Wildlife No. 234,

Washington, D.C.

Elseman, W., 1992. Key Realty, Bowman, North Dakota, personal communication with Sandra Beranich, Environmental Services, Jacobs Engineering Group, Inc., Albuquerque, New Mexico, dated May 28, 1992.

FBDU (Ford, Bacon \& Davis Utah Inc.), 1981a. Engineering Assessment of Inactive Uranium Mill Taillings, Belfield Site, Belfield, North Dakota, DOE/UMT-0122, FBDU 360-21, UC.70, prepared by FBDU, Salt Lake Clty, Utah for the U.S. Department of Energy, UMTRA Project Office, Aibuquerque Operations Office, Albuquerque, New Mexico.

FBDU (Ford, Bacon \& Davis Utah Inc.), 1981b. Engineering Assessment of Inactive Uranium Mill Taillings, Bowman Site, Bowman, North Dakota, DOE/UMT-0122, FBDU 360-22, UC-70, prepared by FBDU, Salt Lake Clty, Utah, for the U.S. Department of Energy, UMTRA Project Office, Albuquerque Operations Office, Albuquerque, New Mexico.

FEMA (Federal Emergency Management Agency), 1983. "FIRM, Flood Insurance Rate Map, Clty of Belfield, North Dakota, Stark County," Community-Panel Number 380116-0001-C, map revised: March 15, 1983.

FWS (U.S. Fish and Wildlife Service) 1992a. "Baird's Sparrow, Ammodramus bairdii," FWS, Bismarck, North Dakota.

FWS (U.S. Fish and Wildlife Service) 1992b. "Loggerhead Shrikes, Lanius Iudourclanus," FWS, Bismarck, North Dakota.

FWS (U.S. Fish and Wildlife Service), 1982. "Recovery Plan for the Peregrine Falcon - Alaska Population," FWS and Alaska Peregrine Falcon Recovery Team.

Faanes, C. A., and R. E. Stewart, 1982. "Revised Checklist of North Dakota Birds," in The Prairie Naturalist, Vol. 14, No. 3, pp. 81-92.

Girard et al. (N. N. Girard, H. Goetz, and A. J. Bjugstad), 1984. "Upland Hardwood Habltat Types in Southwestern North Dakota," in Wooded Draws: Characteristics and Values for the Northern Great Plains, South Dakota School of Mines and Technology, Great Plains Agricultural Councll, Publication No. 111, Rapld City, South Dakota.

Harrington, $F_{\text {, }}$ and Associates, 1984. "An Inventory of Wildlife in Eight Coal Resource Study Areas in Western North Dakota," prepared for the Bureau of Land Management, Dickinson, North Dakota.

Henegar, D. L., 1985. Commissioner, North Dakota Game and Fish Department, Bismarck, North Dakota, personal communication with Charles Burt, Environmental Services, Jacobs Engineering Group, Inc., Albuquerque, New Mexico, dated November 18, 1985. 
Higgins et al. (K. F. Higgins, T. W. Arnold, and R. M. Bartu), 1984. "Breeding Bird Community Colonization of Sown Stands of Native Grasses in North Dakota," in The Prairie Naturalist, Vol. 16, No. 4, pp. 177-182.

Hillman, C. N., and T. W. Clark, 1980. "Mustela nigripes Audubon and Buchman, 1951," in Mammalian Species, No. 126:1-3.

Hoag et al. (A. B. Hoag, T. D. Dahmer, and M. Schrad), 1984. "Rodent Colonization of Revegetated Surface-Mined Lands in Montana and Wyoming," in Issues and Technology in the Management of Impacted Western Wildlife, Proceedings of a National Symposium, sponsored by Thorne Ecological Institute, Boulder, Colorado.

Hogue, L., 1992. Economic Development Coordinator, Roosevelt - Caster Regional Council, Dickinson, North Dakota, personal communication with Sandra Beranich, Environmental Services, Jacobs Engineering Group, Inc., Albuquerque, New Mexico, dated May 27, 1992.

Huschka, P., 1992. President, L. P. Anderson Contractor, Inc., Glendive, Montana, personal communication with Paul E. Martinez, Environmental Services, Jacobs Engineering Group, Inc., Albuquerque, New Mexico, dated June 15, 1992.

Johnson, Kurt, 1987. North Dakota Department of Transportation, Bismarck, North Dakota, personal communication to Sandra Beranich, Environmental Services, Jacobs Engineering Group Inc., Albuquerque, New Mexico, dated September 17 and 21, 1987.

Kincaid, F., 1992. Train Master, Burlington Northern Railroad, Dickinson, North Dakota, personal communication with Sandra Beranich, Environmental Services, Jacobs Engineering Group Inc., Albuquerque, New Mexico, dated May 21, 1992.

Kuchler, A. W., 1975. "Potential Natural Vegetation of the Conterminous United States," American Geographic Society, Special Publication No. 36, New York, New York (Map).

Lisko, R., 1992. Manager, Job Service, Dickinson, North Dakota, personal communication with Sandra Beranich, Environmental Services, Jacobs Engineering Group, Inc., Albuquerque, New Mexico, dated May 27, 1992.

McKenna, M. G., and R. W. Seabloom, 1979. "Endangered, Threatened, and Peripheral Wildlife of North Dakota," Institute for Ecological Studies, University of North Dakota, Grand Forks, North Dakota.

Mount, Dana, 1987. North Dakota State Department of Health, Bismarck, North Dakota, personal communication to Robert C. Peel, Jacobs Engineering Group Inc., Albuquerque, New Mexico, dated November 11, 1987.

NAS (National Academy of Sciences), 1990. Health Effects of Exposure to Low Levels of lonizing Radiation: BEIR-V , Committee on the Biological Effects of lonizing Radiations, National Academy Press, Washington, D.C. 
NDSDH (North Dakota State Department of Health), 1987. "North Dakota Air Quality Monitoring Data Summary 1986," Air Quality Services Branch, Division of Environmental Engineering, Bismarck, North Dakota.

NOAA (National Oceanic and Atmospheric Administration), 1984a. "Climatological Summary, Climatography of the United States No. 20, Dickinson, North Dakota," National Climatic Data Center, Asheville, North Carolina.

NOAA (National Oceanic and Atmospheric Administration), 1984b. "Climatological Summary, Climatography of the United States, No. 20, Bowman, North Dakota," National Climatic Data Center, Asheville, North Carolina.

Paulson, J., 1992. Records Clerk, Saint Lukes Tri-State Hospital Bowman, North Dakota, personal communication with Sandra Beranich, Environmental Services, Jacobs Engineering Group Inc., Albuquerque, New Mexico, dated June 8, 1992.

Reuter, B., 1989. Vice-President, Operations, Pete Lien and Sons, Inc., Rapid City, South Dakota, personal communication with C. H. Persson-Reeves, Environmental Services, Jacobs Engineering Group Inc., Albuquerque, New Mexico, dated May 24, 1989.

Royer, R. A. and G. M. Marrone, 1992. "Conservation Status of the Regal Fritillary (Speyeria idalia) in North and South Dakota," U. S. Fish and Wildlife Service, Denver, Colorado.

Sapa, A. J., 1992. State Supervisor, U.S. Fish and Wildlife Service, Bismarck, North Dakota, personal communication with Chuck Burt, Environmental Services, Jacobs Engineering Group, Inc., Albuquerque, New Mexico, dated March 30, 1992.

Sapa, A. J., 1989. State Supervisor, U.S. Fish and Wildlife Service, Bismarck, North Dakota, personal communication with Bill Glover, Environmental Services, Jacobs Engineering Group, Inc., Albuquerque, New Mexico, dated May 31, 1989.

Seabloom et al. (R. W. Seabloom, R. D. Crawford, and M. G. McKenna), 1978. "Vertebrates of Southwestern North Dakota: Amphibians, Reptiles, Birds, Mammals," Institute for Ecological Studies, University of North Dakota, Grand Forks, North Dakota.

Steinwand, D., 1992. Transportation Planning Department, North Dakota Department of Transportation, Bismarck, North Dakota, personal communication with Sandra Beranich, Environmental Services, Jacobs Engineering Group, Inc., Albuquerque, New Mexico, dated May 20, 1992.

TAC (Technical Assistance Contractor; Jacobs-Weston Team), 1992. "Unpublished Field Notes, Belfield and Bowman, North Dakota, Uranium Mill Tailings Site," unpublished report prepared by the TAC, Albuquerque Operations Office, Albuquerque, New Mexico.

TAC (Technical Assistance Contractor; Jacobs-Weston Team), 1987. "Unpublished Field Notes, Bowman, North Dakota, Uranium Mill Tailings Site," unpublished report prepared by the TAC, Albuquerque, New Mexico, for the U.S. Department of Energy, UMTRA Project Office, Albuquerque Operations Office, Albuquerque, New Mexico. 
TAC (Technical Assistance Contractor; Jacobs-Weston Team), 1986. "Unpublished Field Notes, Belfield and Bowman, North Dakota, Uranium Mill Tailings Site," unpublished report prepared by the TAC, Albuquerque, New Mexico, for the U.S. Department of Energy, UMTRA Project Office, Albuquerque Operations Office, Albuquerque, New Mexico.

TAC (Technical Assistance Contractor; Jacobs-Weston Team), 1985. "Unpublished Field Notes, Belfield and Bowman, North Dakota, Uranium Mill Tailings Site," unpublished report prepared by the TAC, Albuquerque, New Mexico, for the U.S. Department of Energy, UMTRA Project Office, Albuquerque Operations Office, Albuquerque, New Mexico.

UNDAR-WEST (University of North Dakota Archaeology-West), 1988. "Bowman UMTRA site and Griffin Borrow Area Cultural Resource Inventory, Bowman County, North Dakota," prepared by UNDAR-WEST, Belfield, North Dakota, for MK Ferguson Company, Albuquerque, New Mexico.

UNDAR-WEST (University of North Dakota Archaeology-West), 1987. "A Cultural Resource Inventory of Two Uranium Mill Tailings Remedial Action Project Areas in Western North Dakota," (UNDAR-WEST No. 930) prepared by UNDAR-WEST, Belfield, North Dakota for Jacobs Engineering Group Inc., Albuquerque, New Mexico.

USDA (U.S. Department of Agriculture) 1975. Soil Survey of Bowman County, North Dakota, U.S. Department of Agriculture Soil Conservation Service, Washington, D.C.

USDA (U.S. Department of Agriculture) 1968. Soil Survey of Stark County, North Dakota, U.S. Department of Agriculture Soil Conservation Service, Washington, D.C.

White, C. M., and T. L. Thurow, 1985. "Reproduction of Ferruginous Hawks Exposed to Controlled Disturbance," in The Condor, Vol. 87, pp. 14-22.

Woodley, K., 1992. Mayor of Bowman, Bowman, North Dakota, personal communication with Sandra Beranich, Environmental Services, Jacobs Engineering Group, Inc., Albuquerque, New Mexico, dated May 27, 1992.

Zschomler, M.S., 1986. U.S. Fish and Wildlife Service, Bismarck, North Dakota, personal communication with Charles Burt, Environmental Services, Jacobs Engineering Group Inc., Albuquerque, New Mexico, dated March 11, 1986. 


\section{ATTACHMENT 1}

\section{FLOODPLAIN/WETLANDS ASSESSMENT}


TABLE OF CONTENTS

Section Page

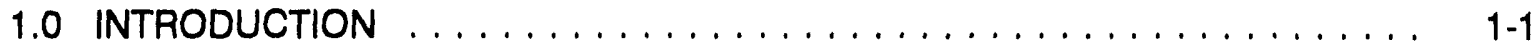

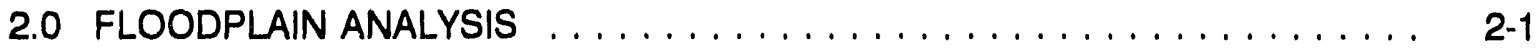

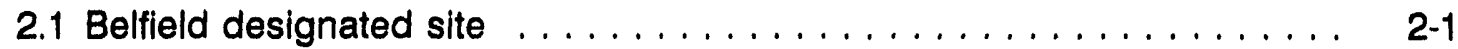

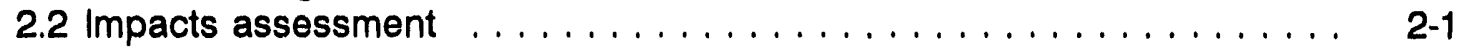

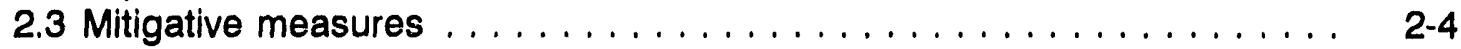

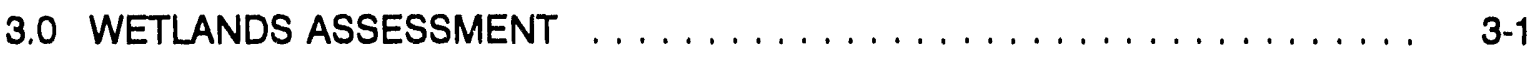

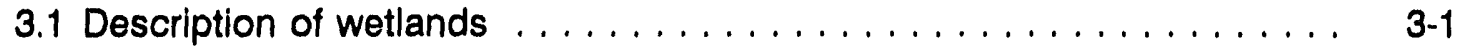

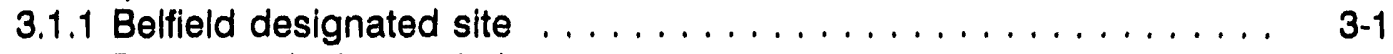

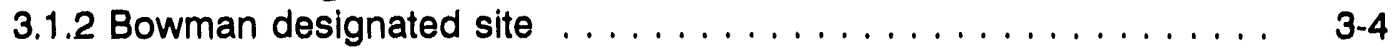

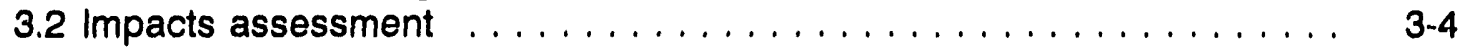

3.2.1 Wooded draw habitat, Belfield site . . . . . . . . . . . . . 3.4

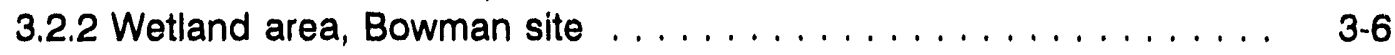

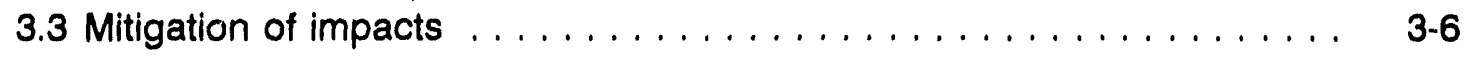

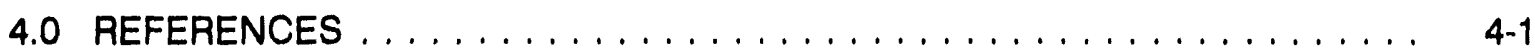




\section{LIST OF FIGURES}

\section{Figure}

Page

2.1 One-hundred-year floodplain boundary, North Branch of the Heart River, Belfield, North Dakota, designated site . . . . . . . . . . . . . . . . . .

2.2 Cross section A-A': maximum water level, 100-year flood event, North Branch of the Heart River, Belfield, North Dakota, designated site . . . . . . . 2-3

3.1 Wooded draw habitat affected by the proposed action, Belfield, North Dakota, designated site . . . . . . . . . . . . . . . . . . . . . . . .

3.2 Wet-meadow wetland habitat affected by the proposed action, Bowman designated site, North Dakota 


\subsection{INTRODUCTION}

The Uranium Mill Tailings Radiation Control Act (UMTRCA) of 1978, as amended, Public Law 95-604, authorized the U.S. Department of Energy (DOE) to clean up the inactive (Title I) uraniferous lignite ashing sites at Belfield and Bowman, North Dakota, to reduce the potential health risks associated with the residual radioactive materials at these sites. Remedial action at these sites must be performed in accordance with the U.S. Environmental Protection Agency's (EPA) standards for inactive uranium processing sites (40 CFR 192, Subparts A and C) promulgated for the remedial action.

In 1979, the DOE issued floodplain/wetlands environmental review requirements (10 CFR 1022) pursuant to Executive Orders 11988, Floodplain Management, and 11990, Protection of Wetlands. The DOE has implemented these requirements consistent with procedures established by the National Environmental Policy Act (NEPA) of 1969. A Notice of Floodplain and Wetland Involvement for Belfield/Bowman and other UMTRA sites was published in the Federal Register February 19, 1988 (53 FR 5033). This attachment provides an assessment of impacts on the floodplains and wetlands affected by the DOE's Uranium Mill Tailings Remedial Action (UMTRA) Project at the Belfield and Bowman, North Dakota, uraniferous lignite ashing sites pursuant to 10 CFR 1022.

The proposed action includes the removal and relocation of radioactively contaminated soils and materials at the Belfield designated site to the Bowman designated site, for codisposal at a permanently restricted 12.1-acre [4.9-hectare (ha)] disposal site. The remedial action would affect the 100- and 500-year floodplain at the Belfield site, which includes the wetlands/wooded draw habitat in the floodplain along the North Branch of the Heart River and a wet-meadow wetland west of the Bowman designated site. The proposed sevenmonth remedial action has been designed to minimize the potential for harm to or within these affected areas, and to conform to all applicable Federal and state regulations. Before construction begins, all applicable permits and approvals, such as those required under Section 404 of the Clean Water Act, would be obtained from the U.S. Army Corps of Engineers (USACE), North Dakota state agencies, and other agencies having jurisdiction. Upon completion of the remedial action, radioactive contamination in the floodplain and wetland areas would be reduced to levels that comply with 40 CFR 192.

The regulations ( 40 CFR 1502.14) implementing the NEPA require that the no action alternative be included in the assessment. Taking no action at the Belfield and Bowman sites would leave the contaminated soils and other contaminated materials in their present condition and would not reduce the potential health risks associated with the contaminated materials. Contamination of the surface water and groundwater from runoff and infiltration would continue. The selection of this alternative would not be consistent with the UMTRCA; reducing the concentrations of the radioactive contamination to within the standards set forth in 40 CFR 192 could not be achieved. 


\subsection{FLOODPLAIN ANALYSIS}

\subsection{BELFIELD DESIGNATED SITE}

The 10.7-acre (4.3-ha) Belfield designated site is within the boundarles of the 100-and 500-year floodplains of the North Branch of the Heart River, except for a small area along the southwestern portion of the site (Figure 2.1) (FEMA, 1983). Remedial action would require the removal of a total of 58,000 cubic yards $\left(\mathrm{yd}^{3}\right)[44,000$ cubic meters $\left(\mathrm{m}^{3}\right)$ ] of contaminated soils from 8 acres ( $3 \mathrm{ha}$ ) within the designated site and approximately 2 acres $(0.8 \mathrm{ha})$ in the floodplain area north of the designated site, which is designated as a vicinity property (i.e., contaminated areas outside the designated site boundary). Because the proposed action does not meet the definition of a "critical action" (10 CFR 1022.4(c) and (i)), an analysis of the 500-year floodplain is not required for this assessment.

Estimates of expected peak flow rates for the North Branch of the Heart River in the immediate site vicinity were interpolated from a U.S. Geological Survey analysis of the annual peak magnitudes versus the annual exceedance probability (log-Pearson transformations) (USGS, 1987). The estimate for the 100-year flood was 8000 cubic feet per second $\left(\mathrm{tt}^{3} / \mathrm{s}\right)\left(200 \mathrm{~m}^{3} / \mathrm{s}\right)$. An estimated probable maximum flood of $48,000 \mathrm{ft}^{3} / \mathrm{s}(1400 \mathrm{~m} / \mathrm{s})$ in the site area was interpolated using actual flow data (Crippen and Bue, 1977). Based on these interpolations, the estimated maximum flow rates would overflow the present banks of the North Branch of the Heart River and submerge the designated site (Figure 2.2).

\subsection{IMPACTS ASSESSMENT}

There are 15 acres (6 ha) of contaminated soils in the North Branch of the Heart River floodplain, 11 acres ( $5 \mathrm{ha}$ ) of which would be remediated (see Section 3.0 of this assessment). Of these 11 acres ( $5 \mathrm{ha})$, the 2 acres $(0.8 \mathrm{ha})$ north of the designated site would be most directly affected. The existing ground cover would be removed, increasing the potential for erosion during heavy rains, in turn increasing the sediment load in the river. Contaminated water produced during vehicle washing and runoff generated during heavy rains could contaminate additional acreage.

After the contaminated soils and vegetation have been removed, the entire affected area would be graded, backfilled where necessary, and recontoured to promote positive drainage. The designated site area would be resurfaced and the vicinity property acreage would be revegetated as soon as practical to prevent erosion. Since the floodplain would be reclaimed after completing the remedial action, the impacts are expected to be temporary, lasting only for the duration of the seven-month remedial action. The vegetation should be reestablished within one growing season.

Revegetation of this area would be monitored and if unsuccessful would be reseeded. Reclamation and revegetation plans for the affected areas would be developed prior to the initiation of remedial activities by the DOE and the Remedial Action Contractor (RAC) in consultation with the appropriate state and Federal agencies.

The surface water and groundwater in the affected area have been contaminated by erosion and infiltration. The long-term positive effect of the remedial action would be 


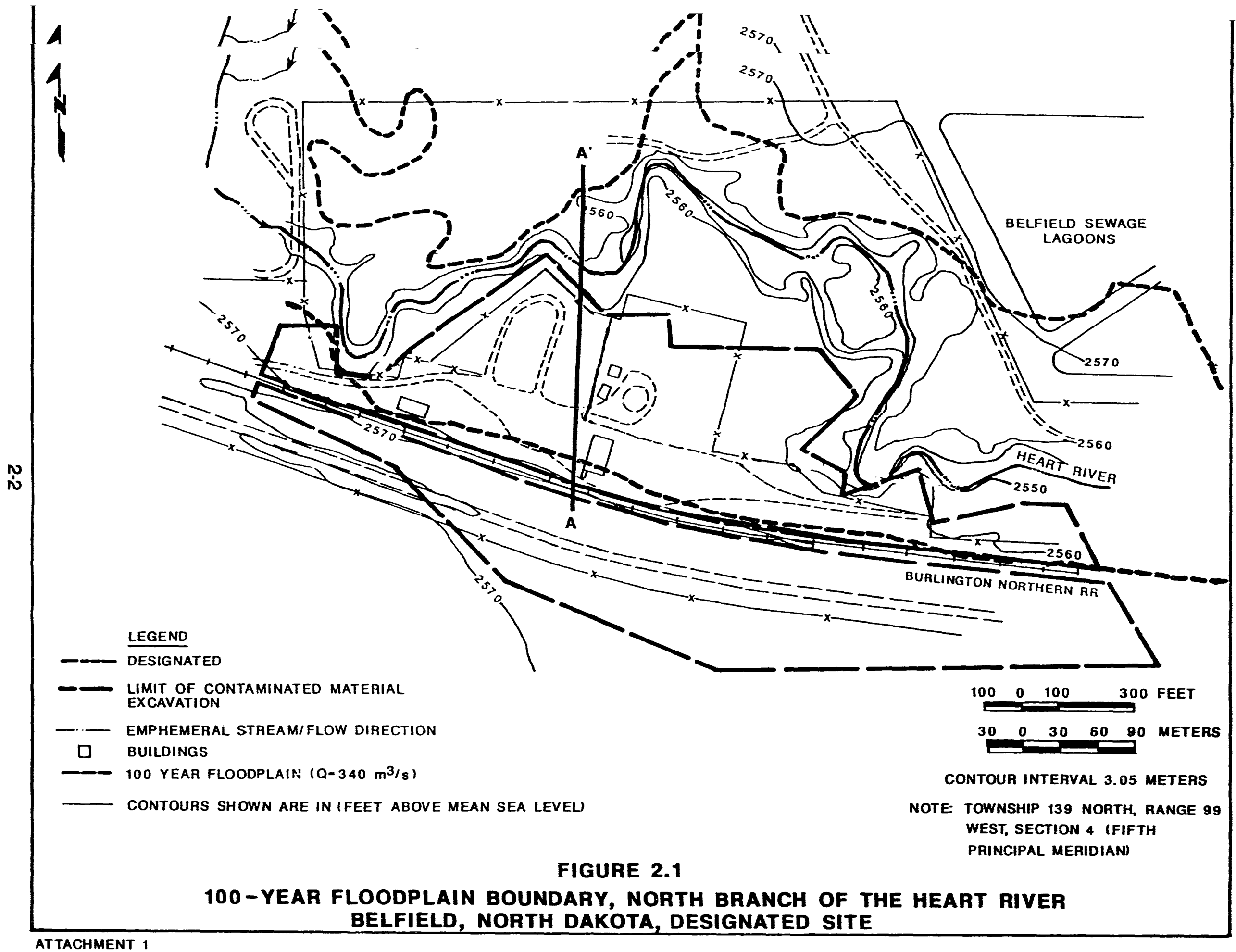




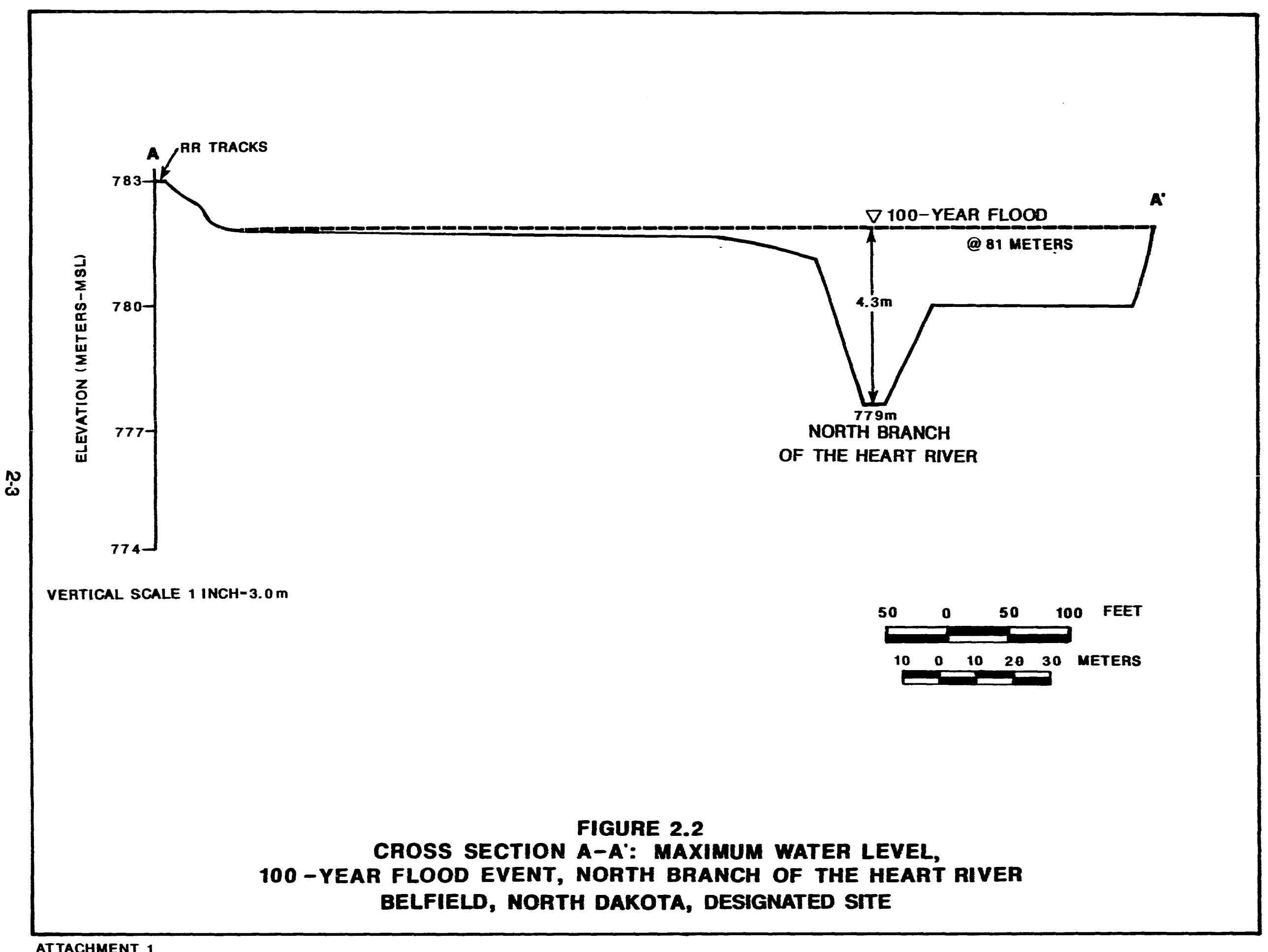


the upgading of surface water quality in the North Branch of the Heart River and the prevention of further contamination of the shallow groundwater system by ellminating the contaminant source (the contaminated floodplain solls).

\subsection{MITIGATIVE MEASURES}

To mitigate impacts to the floodplain during and after the remedial action, the following measures would be implemented:

- Trees in the areas along the river would be left undisturbed to reduce river velocities and associated ercsion in the event of a flood.

- Wastewater retention ponds would be constructed to prevent contaminated construction water and potentially contaminated rain water from leaving the site area, causing erosion during runoff, or contributing to the existing contamination.

- The 11 acres (5 ha) (total) would be reclaimed to promote surface drainage and prevent erosion; soll conditloners would be added if necessary.

- The 2 acres (0.8 ha) north of the designated site would be revegetated as soon as practical. 


\subsection{WETLANDS ASSESSMENT}

\subsection{DESCRIPTION OF WETLANDS}

Fleld reconnaissance surveys of the wooded draw at the Belfield site and the wetmeadow wetland at the Bowman slte were conducted in November 1985 and June 1986 and 1987, respectively (TAC, 1992; 1987a,b; 1986; 1985; DOE, 1983a,b); unless specifically noted otherwise, the discussions provided below reference these surveys and the biological assessment (DOE, n.d.) which presents the results of these surveys.

\subsubsection{Belfield designated slte}

The wooded draw habltat in the floodplain along the North Branch of the Heart River (Figure 3.1) is a USACE regulated wetlands (Disbro, 1986) and is also considered a unique habitat type by the U.S. Fish and Wildlife Service (FWS) (Collins, 1987; Zschomler, 1986). Wooded draws are uncommon in North Dakota; they occur as isolated stands and make up only five to seven percent of the total vegetative cover in the southwestern part of the state (Girard et al., 1984). About 2 acres ( $0.8 \mathrm{ha}$ ) of this habitat are included in the total contaminated floodplain acreage [15 acres (6 ha)].

At the Belfield sile, the wooded draw plant community is the Fraxinus pennsylvania (greerl ash)/Ulmus americana (American elm)/Prunus virginianus (choke cherry) type (Girard et al., 1984). An occasional Russian olive (Elaeagnus angustifolia), box-elder (Acer negundo), and cottonwood (Populus deltoldes) also occur. Chokecherry is a tall shrub iri the understory and snowberry (Synpnoricarpos occidentalis) is the most common low-growing shrub. The dominant ground cover is grass; various herbaceous plant species also occur here. The area is actlvely grazed by cattle and the ground cover is relatively short in most areas. In June 1986 the woody plants (especially elm) were being defoliated by insects; fairly large stands of trees along the river were almost totally defollated. In addition, some of the large trees were beginning to die off and little reproduction was observed, presumably because of the grazing. These woods appear to be in a state of decline, as has been observed in other hardwood draws in southwestern North Dakota (Girard et al., 1984).

The North Branch of the Heart River flows intermittently; no flow was observed in November 1985, and very little flow was observed during June 1986. Emergent aquatic vegetation grows in narrow bands along the river with various species of rushes (Juncus sp.), sedges (Carex sp.), bulrushes (Scripus sp.), and arrowhead (Sagittaria sp.) commonly observed. Log jams and snags were noted along the river, presumably as a result of high water.

The chorus frog (Pseudacris triseriata) and plains garter snake were recorded near the wooded draw area (DOE, 1983a); 11 additional reptile and amphibian species may occur in the site area (Hopkins, 1984; Wheeler and Wheeler, 1966).

Quantitative nesting bird studies in North Dakota indicate that wooded draw habitat is up to eight times more productive than other habltat, supporting a more diverse 


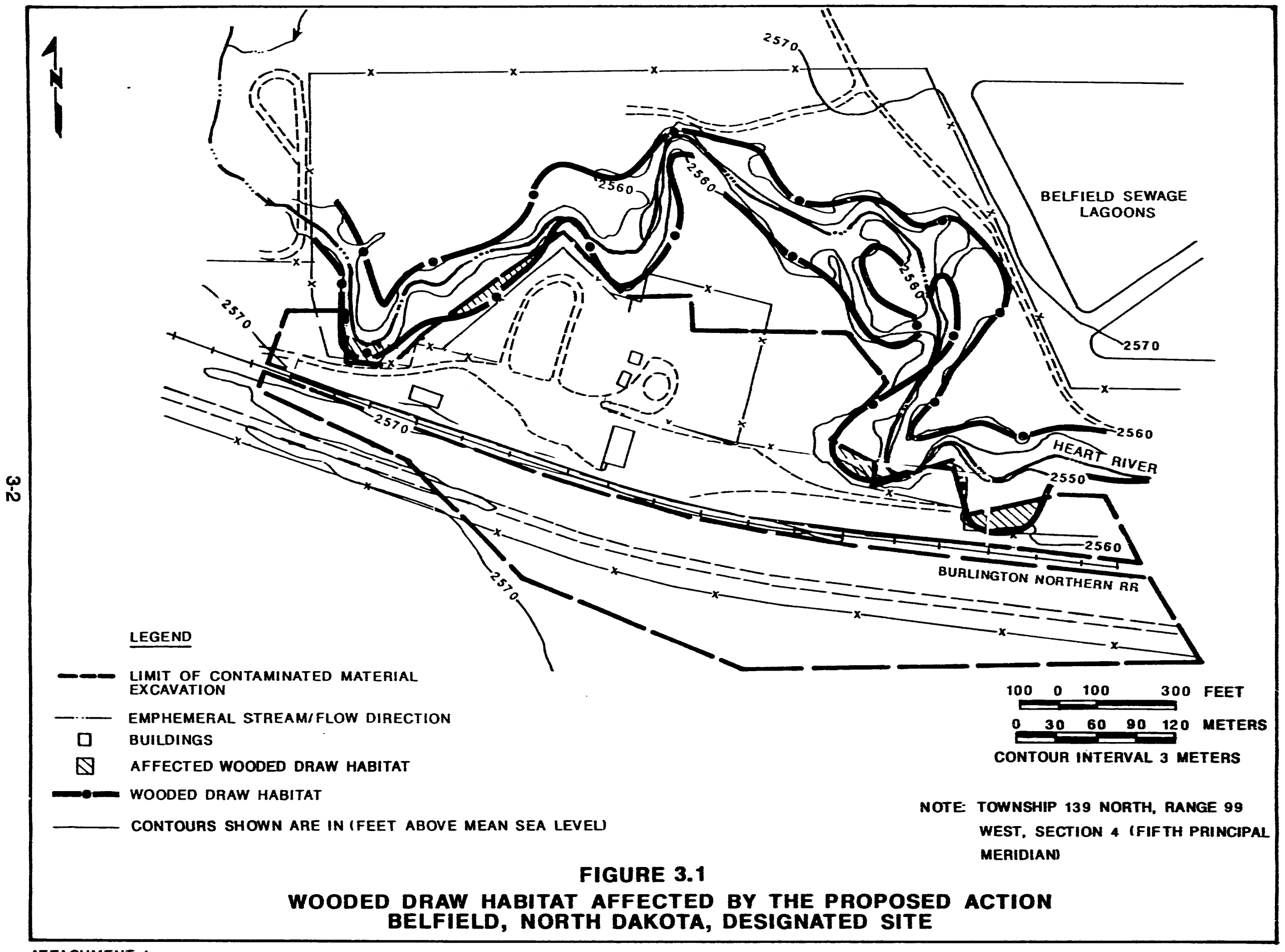


assemblage of bird life, than grassland or short-grass prairie habltat (Hopkins et al., 1986; VanVelzen, 1980). Observations at the Belfield site confirmed this; thirty-six species of breeding birds were observed in the wooded draw, while only 18 specles were recorded from nearby upland habltats. A total of 21 nesting species (151 nesting pairs) were recorded during a four-hour survey along the river in June 1986 while 21 species comprising 121 nesting pairs were recorded in 1992. The most common species were the mourning dove (Zenaida macroura), house wren (Troglodytes aedon), robin (Turdus migratorlus), and yellow warbler (Dendroica petechla). Twenty-four percent of the birds observed in 1986 were cavity nesters and 32 percent were cavity nesters in 1992; the house wren was the most common cavity nester (DOE, n.d.).

Raptors observed in the area were the turkey vulture (Cathartes aura), American kestrel (Falco sparverius), and great horned owl (Bubo virginianus), all of which are potential nesting species along the Heart River, although nests were not observed. The Cooper's hawk (Acciplter cooperil)and red-talled hawk (Buteo lamaicensis) were not observed at the site, but are raptors that nest in wooded draws in southwestern North Dakota (Hopkins, 1984).

Upland game birds observed in the site area were the gray partridge (Perdix perdix), an introduced species that has adapted well to agricultural areas, and several species of water fowl. The sharp-tailed grouse (Tympanuchus phasianellus) and ring-necked pheasant (Phasianus cochicus) may also occur in the area.

The mallard (Anus platyrhynchos) was the only confirmed nesting specie of waterfowl along the river. In June 1986, three broods and an additional "broody" female were observed along a $6000-\mathrm{ft}(1800-\mathrm{m})$ section of the river at and east of the site. The broods ranged from newly hatched to about three-quarters grown. The river provides escape cover and areas of emergent vegetation that support the food source necessary for duck broods; log jams and debris provide additional escape cover. Inadequate stream flow during the nesting season and poor water quality in the site area are factors that limit the usefulness of the river as nesting waterfowl habitat. The southwestern slope region of the state covers 26.9 percent of the state, yet only four percent of the state's waterfowl production occurs in this area. Of the wetlands in the region, streams such as the North Branch of the Heart River comprise 41 percent of the wetlands habitat, yet only five percent of the region's waterfowl production occurs in this habitat type (Stewart and Kantrud, 1973).

Six species of mammals were observed in the wooded draw in November 1985, including two striped skunks (Mephitis mephitis) found dead along the river. An additional 11 species of mammals may occur in this area (Harrington and Associates, 1984; Seabloom et al., 1978). The mule deer (Odocolleus hemlonus), white-tailed deer (Odocolleus virginianus), and pronghorn antelope (Antilocapra americana) are known to occur, but have not been observed in the wooded draw. Given the relatively high levels of human activity in the area, big games species are not likely to occur in the site area. 


\subsubsection{Bowman designated site}

There is a wet-meadow wetland west of the Bowman designated site along an unnamed tributary to Spring Creek that is a USACE-designated wetland (Figure 3.2) (Disbro, 1986). Four acres (2 ha) of wetland soils contaminated by the lignite ashing process would be removed during the remedial action.

This wetland is flooded only during the spring after snowmelt; no standing water was observed during the two summer field surveys. This area had not been mowed or grazed and the vegetation cover was dense and high. Cordgrass (Spartina sp.), bluegrass (Poa pratensis), sedges, and rushes were the common plant species observed. The wetland does not provide suitable habitat for nesting waterfowl or other waterbirds, although it may provide habitat for migratory waterbirds in the spring when standing water is present. Wildlife species observed in this area were typical of species found in the surrounding uplands.

\subsection{IMPACTS ASSESSMENT}

\subsubsection{Wooded draw habitat, Belfield site}

As stated in Section 3.1.1, wooded areas are rare in southwestern North Dakota; 2 acres $(0.8 \mathrm{ha})$ of wooded draw habitat, also classified as Wetlands by the USACE, are within the 15-acre (6-ha) contaminated area scheduled for cleanup during the remedial action. The state of North Dakota requested that alternatives to destroying this habitat be developed. The wooded draw unique habitat is outside the Belfield designated site boundary and has vicinity property status. Subpart $C$ of the EPA standards allows the DOE to apply supplemental standards [40 CFR 192.12(a) and (c)] to vicinity property sites if remedial actions to satisfy cleanup standards for land would directly produce environmental harm that is clearly excessive compared to the health benefits to persons living on or near the site, now or in the future (40 CFR 192.21(b)).

Analysis of samples collected from this habitat indicated that the average radium-226 (Ra-226) concentration was 8.3 picocuries per gram $(\mathrm{pCi} / \mathrm{g})]$ [0.31 becquerels per gram $(\mathrm{Bq} / \mathrm{g})]$; a radon flux of 2.4 picocuries per square meter per second $\left(\mathrm{pCi} / \mathrm{m}^{2} \mathrm{~s}\right)$ $\left[0.09\right.$ becquerels per square meter second $\left.\left(\mathrm{Bq} / \mathrm{m}^{2} \mathrm{~s}\right)\right]$ was estimated for this 2-acre (0.8-ha) area (DOE, 1989). The 2 acres $(0.8 \mathrm{ha})$ of wooded draw habitat within the excavation limits are only 6 percent of the total contaminated area 29.3 acres (11.8 ha). Given the low average Ra-226 concentrations, radon flux, absence of people living in direct proximity to this habitat, the small area of habitat affected, and the unique nature of this plant community, the long-term environmental loss of this unique habitat would be considered a case of excessive environmental harm when compared to the human health benefits derived from the remedial action. It takes a number of years to reestablish the woody plant communities. Experience at mine sites in western North Dakota indicates that wooded draws can be successfully revegetated with original plant species (Nielson, 1988).

A final determination regarding the need to excavate these areas would be made prior to the initiation of remedial action, in consultation with the state of North Dakota. The data, the results of the analysis, and any remedial action required, would be included in 


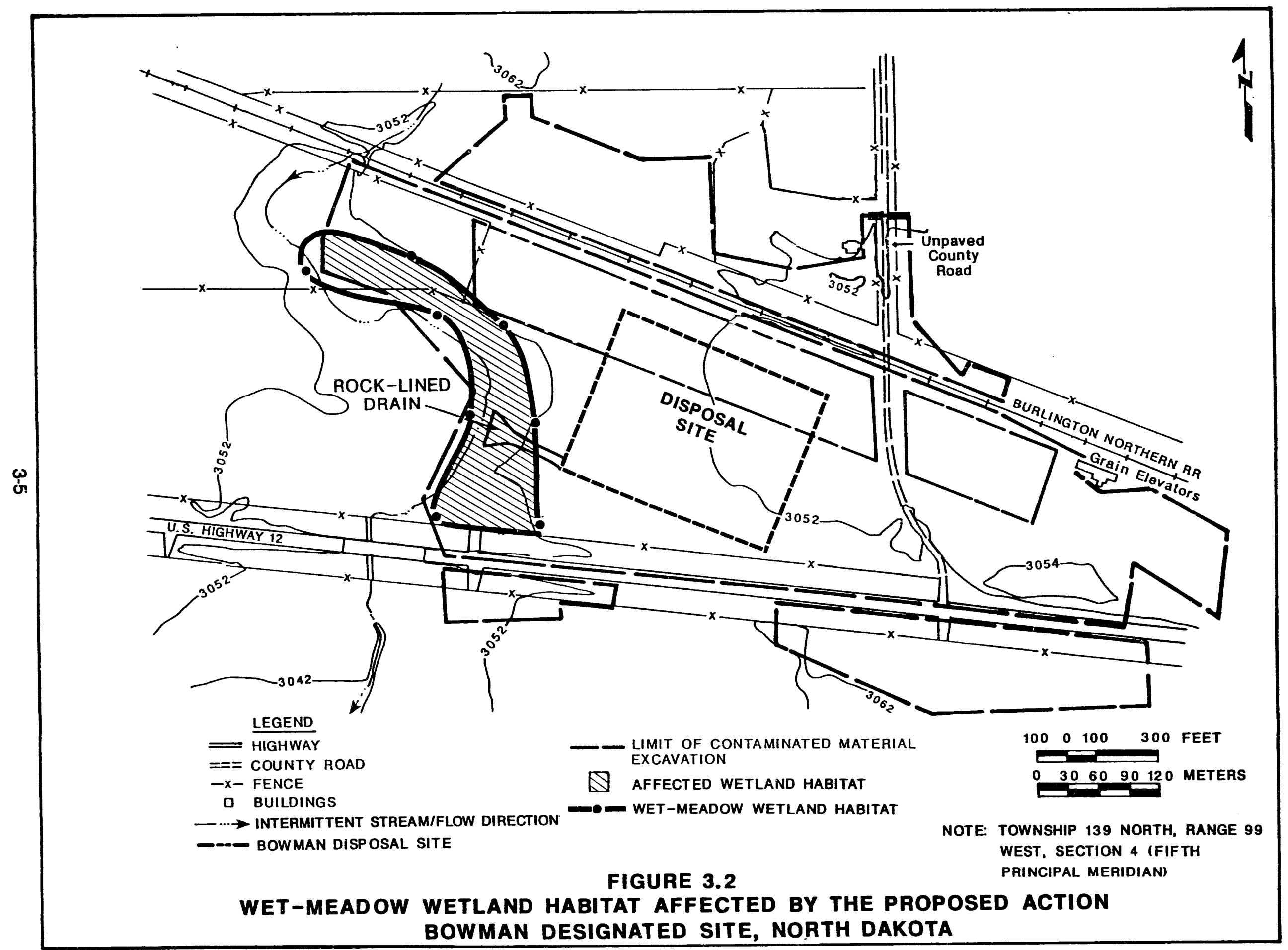

ATTACHMENT 1 
the vicinity property completion reports submitted to the U.S. Nuclear Regulatory Commission as part of the site certification process.

\subsubsection{Wetland area, Bowman site}

The wetland area west of the Bowman site covers 4 acres (2 ha) outside the designated site boundary. As part of the remedial action, the vegetation and contaminated soil within this wetland would be removed. When the remedial action is completed, a permanent rock-lined drain from the disposal cell would extend into the affected wetland area (Figure 3.2). When the remedial action is complete, this area would be reclaimed as a wet meadow wetland. The affected wetland and other appropriate areas would be revegetated in accordance with a detailed reclamation plan developed by the RAC in consultation with the USACE, FWS, and appropriate state and Federal agencies. The impacts associated with this action would be short-term; wet meadow wetlands can be reestablished within two to three years.

\subsection{MITIGATION OF IMPACTS}

In the event that removal of the wooded draw habitat at the Belfield site cannot be avoided, revegetation of this habitat also is the only measure available to off-set the impacts. However, for the reasons stated above, the successful reestablishment of this area may be difficult. If this were to occur, the following measures would be taken to reestablish this habitat:

- Recontouring of excavated areas to promote drainage and create favorable conditions for reestablishing the vegetation.

- If possible, revegetating the area with woody plant species that currently exist using tree and shrub transplants (selected after consultation with appropriate agency personnel) and mulching to conserve ground moisture. Grass and herb species would be used if using the woody species is not feasible. Livestock access would be restricted until the vegetation is reestablished.

- Selective use of water bars, mulch, riprap, or other soil erosion controls to minimize erosion that would otherwise impede revegetation efforts.

There is no alternative to destroying the wet meadow wetland at the Bowman site; therefore, reclamation and revegetation is the only measure available to off-set the impacts. Given the small area the toe of the rock drain would occupy at the edge of the reclaimed wetland, the long-term effects of this feature are expected to be minimal. The presence of the permanent disposal facility would have no affect on the wetland. 


\subsection{REFERENCES}

Collins, Roger, 1987. U.S. Fish and Wildlife Service, Bismarck, North Dakota, personal communication with C. H. Persson-Reeves, Environmental Services, Jacobs Engineering Group Inc., Albuquerque, New Mexico dated October 30, 1987.

Crippen, J. R., and C. D. Bue, 1977. Maximum Floodflows in the Conterminous United States, U.S. Geological Survey, Water-Supply Paper 1887, U.S. Government Printing Office, Washington, D.C.

DOE (U.S. Department of Energy), n.d., in preparation. "Biological Assessment for the Inactive Uraniferous Lignite Ashing Sites at Belfield and Bowman, North Cukota," UMTRA-DOE/AL-___ prepared by the U.S. Department of Energy, UMTFIA Project Office, Albuquerque Operations Office, Albuquerque, New Mexico.

DOE (U.S. Department of Energy), 1989. "Remedial Action Plan and Site Conceptual Design for Stabilization of the Inactive Uraniferous Lignite Processing Sites at Belfield and Bowman, North Dakota," UMTRA-DOE/AL-050522.0000, unpublished preliminary final, prepared by the U.S. Department of Energy, UMTRA Project Office, Albuquerque Operations Office, Albuquerque, New Mexico.

DOE (U.S. Department of Energy), 1983a. "Environmental Assessment of Remedial Actions on the Uranium Residues at the Belfield Site, Stark County, North Dakota," prepared by the U.S. Department of Energy, UMTRA Project Office, Albuquerque Operations Office, Albuquerque, New Mexico.

DOE (U.S. Department of Energy), 1983b. "Environmental Assessinent of Remedial Actions on the Uranium Residues at the Bowman Site, Bowman County, North Dakota," unpublished report, prepared by the U.S. Department of Energy, UMTRA Project Office, Albuquerque Operations Office, Albuquerque, New Mexico.

Disbro, Sam, 1986. U.S. Army Corps of Engineers, Omaha, Nebraska, personal communication with Charles J. Burt, Environmental Services, Jacobs Engineering Group Inc., Albuquerque, New Mexico, dated March 6, 1986.

FEMA (Federal Emergency Management Agency), 1983. "FIRM, Flood Insurance Rate Map, Stark County, ND, Unincorporated Area," panel 11 of 15, community-panel number 3853690011 B, map revised: September 28, 1982.

Girard et al. (N. N. Girard, H. Goetz, and A. J. Bjugstad), 1984. "Upland Hardwood Habitat Types in Southwestern North Dakota," in Wooded Draws: Characteristics and Values for the Northern Great Plains, South Dakota School of Mines and Technology, Great Plains Agricultural Council, Publication No. 111, Rapid City, South Dakota.

Harrington, F., and Associates, 1984. "An Inventory of Wildlife in Eight Coal Resource Study Areas in Western North Dakota," prepared for the Bureau of Land Management, Dickinson, North Dakota. 
Hopkins et al. (R. B. Hopkins, J. F. Cassel, and A. J. Bjugstad), 1986. "Relationships Between Breeding Birds and Vegetation in Four Woodland Types in the Little Missouri National Grasslands," U.S. Forest Service, Rocky Mountain Forest and Range Experiment Station, Research Paper RM-270, Fort Collins, Colorado.

Hopkins, R. B., 1984. "Avian Species Associated with Prairie Woodland Types," in Wooded Draws: Characteristics and Values for the Northern Great Plains, South Dakota School of Mines and Technology, Great Plains Agricultural Council, Publication No. 111, Rapid City, South Dakota.

Nielson, D., 1988. Glenharold Mine, North Dakota, personal communication with Charles J. Burt, Environmental Services, Jacobs Engineering Group Inc., Albuquerque, New Mexico, dated July 25, 1988.

Seabloom et al. (R. W. Seabloom, R. D. Crawford, and M. G. McKenna), 1978. "Vertebrates of Southwestern North Dakota: Amphibians, Reptiles, Birds, Mammals," Institute for Ecological Studies, University of North Dakota, Grand Forks, North Dakota.

Stewart, R. E., and H. A. Kantrud, 1973. "Ecological Distribution of Breeding Waterfowl Populations in North Dakota," in Journal of Wildlife Management, Vol. 37, pp. 39-50.

TAC (Technical Assistance Contractor; Jacobs-Weston Team), 1992. "Unpublished Field Notes, Belfield and Bowman, North Dakota, Uranium Mill Tailings Site," unpublished report prepared by the TAC, Albuquerque Operations Office, Albuquerque, New Mexico.

TAC (Technical Assistance Contractor; Jacobs-Weston Team), 1987a. "Unpublished Field Notes, Belfield and Bowman, North Dakota, Uranium Mill Tailings Site," unpublished report prepared by the TAC, Albuquerque, New Mexico, for the U.S. Department of Energy, UMTRA Project Office, Albuquerque Operations Office, Albuquerque, New Mexico.

TAC (Technical Assistance Contractor; Jacobs-Weston Team), 1987b. "Unpublished Field Notes, Bowman, North Dakota, Uranium Mill Tailings Site," unpublished report prepared by the TAC, Albuquerque, New Mexico, for the U.S. Department of Energy, UMTRA Project Office, Albuquerque Operations Office, Albuquerque, New Mexico.

TAC (Technical Assistance Contractor; Jacobs-Weston Team), 1986. "Unpublished Field Notes, Belfield and Bowman, North Dakota, Uranium Mill Tailings Site," unpublished report prepared by the TAC, Albuquerque, New Mexico, for the U.S. Department of Energy, UMTRA Project Office, Albuquerque Operations Office, Albuquerque, New Mexico.

TAC (Technical Assistance Contractor; Jacobs-Weston Team), 1985. "Unpublished Field Notes, Belfield and Bowman, North Dakota, Uranium Mill Tailings Site," unpublished report prepared by the TAC, Albuquerque, New Mexico, for the U.S. Department of Energy, UMTRA Project Office, Albuquerque Operations Office, Albuquerque, New Mexico. 
USGS (U.S. Geological Survey), 1987. Flow data for USGS gauging station number 06343000 , provided by the Bismarck District Office of the U.S. Geological Survey, North Dakota, Water Resources Division, September, 1987, avallable from Project Document Control, UMTRA Project Office, Albuquerque Operations Office, Albuquerque, New Mexico.

VanVelzen, W. T., 1980. "Forty-Third Breeding Bird Census," in American Birds, Vol. 34, No. 1.

Wheeler, G. C., and J. Wheeler, 1966. "The Amphibians and Reptiles of North Dakota," The University of North Dakota, Grand Forks, North Dakota.

Zschomler, M. S., 1986. U.S. Fish and Wildlife Service, Bismarck, North Dakota, personal communication with Charles J. Burt, Environmental Services, Jacobs Engineering Group Inc., Albuquerque, New Mexico, dated March 11, 1986. 
ATTACHMENT 2

U.S. FISH AND WILDLIFE SERVICE LETTERS 


\section{United States Department of the Interior}

FISH AND WILDLIFE SERVICE

FISH AND WILDLIFE ENHANCEMENT

ISOO EAST CAPITOL AVENLIE

BISMARCK, NORTH DAKOTA 58501

Mr. William Glover, Manager

Environmental Services

Jacobs Engineering Group, Inc.

5301 Central Ave. NE - Suite 1700

A7buquerque, New Mexico 87108

Dear Mr. Glover:

This responds to your letter of March 30, 1992, requesting a list of federally endangered and threatened species that may be present within the Uranium Mill Tailings Remedial Action (UMTRA) Project sites in North and South Dakota; see enclosure. This list fulfills requirements of the Fish and Wild iffe Service (Service) under Section 7 of the Endangered Species Act. For each species listed, I have provided a brief description of the habitats where they might be expected to occur. At this time, I am not aware of any geographic features or habitats within the specific project area that would be especially important to the species, nor are any of the species known to frequent the project area. The Department of Energy, or its delegated agent, is required to evaluate whether the proposed action may affect endangered or threatened species. If it is determined the proposed action "may affect" listed species, the Department of Energy shall request formal Section 7 consultation with this office. If the evaluation shows a "no effect" situation on the listed species, further consultation is not necessary.

I have also provided a list of category 2 (candidate) species whose habitats may be present within the project area. Candidate species are defined as those which may appropriately belong on the endangered or threatened list, but which lack conclusive data on biological vulnerability and threat to support proposed rules. There is no legal requirement to protect candidate species, but it is within the spirit of the Endangered Species Act to consider these species and impacts of Federal actions. Impacts to these species can be reduced if losses to native wondland, native grassland, wetland, and riverine habitats are avoided where possible.

If changes are made to the project plans or if additional information becomes available, the Department of Energy, or its delegated agent, must evaluate the impacts of proposed changes upon threatened or endangered species.

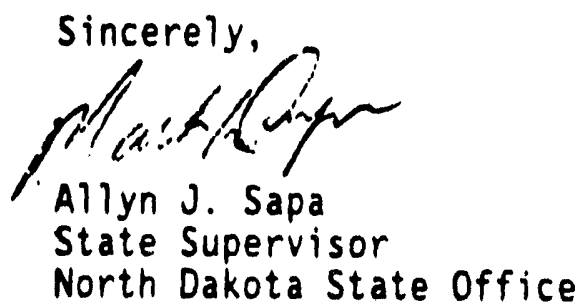




\section{Enclosure}

cc: Supervisor, FWE, Pierre 
FEDERAL THREATENED, ENDANGERED, AND CANDIDATE SPECIES FOUND IN

STARK AND BOWMAN CDUNTY, NORTH DAKOTA

AND

PENNINGTON COUNTY, SOUTH DAKOTA

\section{ENDANGERED SPECIES}

Bald eagle (Haliaeetus leucocephalus): Migrates spring and fall statewide but primarily along the major river courses. It concentrates along the Missouri River during winter and is known to nest in the floodplain forest.

Black-footed ferret (Mustela nigripes): Exclusively associated with prairie dog towns. No records of occurrence in recent years, al though there is potential for reintroduction in the future.

Peregrine falcon (Falco peregrinus): Migrates spring and fall statewide but primarily along the major river courses. Historic nesting has been recorded in the Badlands.

Whooping crane (Grus Americana): Migrates through west and central counties during spring and fall. Prefers to roost on wetlands and stockdams with good visibility. Young adult summered in North Dakota in 1989 and 1990. Total population 140-150 birds.

American Burying Beetle (Nicrophorus americanus): Historic records in South Dakota. Associated with deciduous woodlands.

\section{LISTED CANDIDATE-CATEGORY II}

Ferruginous hawk (Buteo regalis): Nests in rugged prairie of the central and southwestern counties.

Regal fritillary butterfly (Speyeria idalia): Locally common in the Sheyenne National Grasslands. Prefers undisturbed moist prairie. Scattered records in western counties.

Swift fox (Vulpes velox): Primarily inhabits mid and short grass prairie of the western counties. Sightings only known from Mercer and Slope Counties.

Baird's sparrow (Ammodramus bairdii): Nests in extensive, idle or lightly grazed mixed-grass prairie throughout North Dakota, but more commonly in the prairie pothole region.

Loggerhead shrike (Lanius ludovicianus): Nests in thickets of small trees and shrubs or sheiterbelts adjacent to native prairie or cropland. More commonly found in the southwestern counties, but can be found statewide. 


\section{TI JACOBS ENGINEERING GROUP INC.

5301 CENTRAL AVEN'JE N.E. - SUITE 1700, ALBUQUERQUE, NEW MEXICO 87108

TELEPHONE (505) 845.1530

March 30, 1992

Alen Sapa, Btate Suparvisor

U.8. Fish and Widlife Enhaneoment Sorvioe 1600 Captol Avenue

Blemarok, ND 88501

Dov Mr. Sepa:

I en witting your office to update our consultation regarding throafenod and ondangered species (T\&E) and other species of coneom that may oceur near the Belfield and Bowman, North Dakota Uranium Mill Tallings Romedial Aetion (UMTRA) Project sttes. Jacobs Engincering Croup, Ine. is the Technical Assistance Contractor for the U.S. Dopartment of Enorgy (DOE) for the UMTRA Project.

We are in the process of finalizing the Environmental Assessment (EA) for the Belfield and Bowman sttes. Our initial consuttation with your office was a lottor dated January 22, 1986, that wes sent to your Grand lsland, Nebraska offioe. The response from that office of February 4 , 1086 listed the specles that may occur af the project sttes. This consultation was updated in May of 1089 whon a latter dated May 1, 1089 was sent to your office. Your response (dated May 31, 1989) Identified six potential species of concem (I have onclosed a copy of your May 31, 1089 lotter).

The proposed action is to move the contaminated material at the Baffield stte to the Bowman stte for stabilization. The redon barrier (a clay soll cover) will be obtained from a borrow stte across the road from the Bowman stte. Rock erosion protection matorial may be obtained from on existing rock quarry in South Dakota. I have enclosed maps showing the location of the Baffield and Bowman sttes and the rock borrow site in South Dakota.

My request is that you provide me with an updated list of the T\&E species from our sttes in North and South Dakota. Your response will be reforenced in the EA. 
II you have any questions, plases contaof me of Chuok Burt of my staff at (608) $846-5700$.

Thank you for aseleting us in diaposing of the contaminated matorials af the Bofficld and Bowman sttes in an environmentally sound manner.

Vory truly yours.

LACOBS ENGINEERING GROUP, INC.

Bapd

Wllaw Q Benne

William A. Clovor,

Environmontal Eervioes Managor

UMTRA

Enolosures

c: CBunt

PMartinaz

CYanooy

Dooument Control 


\section{MAY 812989}

Mr. B111 Glover, Manager

Environmental Services

Jacobs Engineering Group. Inc.

5301 Central Ave. ME - Sutte i700

Albuquerque, Mew Mextco 87108

Dear Mr. Glover:

This responds to your letter of May 1, 1989, requesting a list of federally endangered and threatened spectes that may be present within the Uranfum Mill Tallings Remedial Aetion (UNTRA) Project sites in North and South Dakota; see attachment. This list fulfills requirements of the Fish and Wildilfe Service (Service) under Section 7 of the Endangered Species Act. For each species Iisted, I have provided a brief description of the habitats where they might be expected to occur. At this time, I am not aware of any geographic features or habitats within the specific project area that would be espectally important to the species, nor are any of the spectes known to frequent the project area. The Department of Energy, or its delegated agent, is requited to evaluate whether the proposed action may affect endangered or threatened species. If It is determined the proposed action "may affect" I1sted species, the Department of Energy shall request formal Section 7 consultation with this office. If the evaluation shows a "no effect" situation on the listed spectes, further consultation is not necessary.

I have also provided a list of Category II (candidate) species whose habltats may be present within the project area. Candidate species are defined as those which may appropriately belong on the endangered or threatened list, but wich lack conclusive data on biological vulnerability and threat to support proposed rules. There is no legal requirement to protect candidate species. but $1 t$ is within the spirit of the Endangered Specles Act to consider these spectes and impacts of federal actions. Impacts to these species can be redueed if losses to native woodiand, native grassiand, wetland and riverine habltats are avolded where possible.

If changes are ande to the project plans or if additional information becomes avallable, the Department of Energy, or Its delegated agent, must evaluate the impacts of proposed changes upon threatened or endangered species.

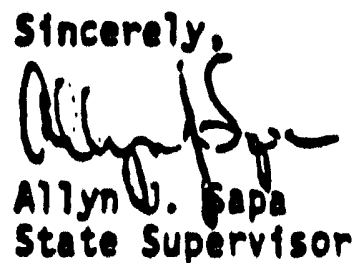


FEderal thrEATENED, ENDANGERED, aNd CANDIDATE SPECIES

BOMMAN AND STARK COUNTIES, NORTH DAKOTA

SPECIES

LISTED ENDANGERED

Baid cagle (Halracetus leucocophalus)

Black-footed forret (Mustela nigripes)

Peregrine falcon (Falco peregrinus)

Whooping crane (Grus Americana)

* LISTED CANDIDATE-CATEGORY II

Ferruginous hawk (Buteo regalis)

Long-billied curlew (Numenius Americanus)

Sturgeon chub (Hybopsis gelida)

Swlft fox (Vulpes velox)
EXPECTED OCCURRENCE/HABITAT

Migrates spring and fall statewide but primartly along major river courses. Concentrates along Missourl River during winter. Known to nest along Missouri River.

Pratrie dog towns. No records of occurrence in recent years.

Migrates spring and fall statewide but primarlly along major river courses.

Migrates through west and central counties during spring and fall. Prefers to roost on wetlands and stockdams with good visibility.

Nest and raise young in rugged prairie of central and southwest countíes.

Nest and raise young in short and mixed grass prairie of southwest counties.

Large, turbid streams with rock or gravel bottom.

Mid and short grass prairle of western counties. Sightings only known from Mercer and siope counties.

PENNINGTON COUNTY, SOUTH DAKOTA

- LISTED ENDANGERED, thREATENED, CANDIDATE

None within project aree 
ATTACHMENT 3

ACRONYMS 


\section{ACRONYMS}

$\begin{array}{ll}\text { ADT } & \text { average daily traffic } \\ \text { AML } & \text { Abandoned Mine Lands } \\ \text { DOE } & \text { U.S. Department of Energy } \\ \text { EA } & \text { environmental assessment } \\ \text { EADR } & \text { Environmental Analysis and Data Report } \\ \text { EPA } & \text { U.S. Environmental Protection Agency } \\ \text { FWS } & \text { U.S. Fish and Wildlife Service } \\ \text { MCL } & \text { maximum concentration levels } \\ \text { NEPA } & \text { National Environmental Policy Act } \\ \text { NRC } & \text { U.S. Nuclear Regulatory Commission } \\ \text { RAC } & \text { Remedial Action Contractor } \\ \text { T\&E } & \text { threatened and endangered } \\ \text { UMTRA } & \text { Uranium Mill Tailings Remedial Action } \\ \text { UMTRCA } & \text { Uranium Mill Tailings Radiation Control Act } \\ \text { USACE } & \text { U.S. Army Corp of Engineers }\end{array}$




\section{Finding of No Significant Impact \\ Proposed Remedial Action \\ Uraniferous Lignite Ashing Sites \\ Belfield and Bowman, North Dakota}

AGENCY: Department of Energy

ACTION: Finding of No Significant Impact (FONSI) and Floodplain

Statement of Findings

SUMMARY: The U.S. Department of Energy (DOE) has prepared an environmental assessment (EA) (DOE/EA-0346) on the proposed remedial action for the Belfield and Bowman uraniferous lignite ashing sites, North Dakota. Based on the analysis in the EA, the DOE has determined that the proposed action does not constitute a major Federal action significantly affecting the quality of the human environment as defined in the National Environmental Policy Act (NEPA) of 1969 (42 U.S.C. 4321 et seq.). Therefore, preparation of an environmental impact statement is not required and the DOE is issuing this Finding of No Significant Impact (FONSI).

SINGLE COPIES OF THE EA ARE AVAILABLE FROM:

Albert Chernoff, Project Manager UMTRA Project office U.S. Department of Energy 5301 Central Avenue, N.E., Suite 1720 Albuquerque, New Mexico 87108 (505) $845-4628$ 
FOR FURTHER INFORMATION ON THE NEPA PROCESS, CONTACT:

Carol M. Borgstrom, Director

Office of NEPA Oversight

U.S. Department of Energy

1000 Independence Avenue, S.W.

Washington, D.C. 20585

(202) $586-4600$ or (800) $472-2756$

BACKGROUND: On November 8, 1978, the Uranium Mill Tailings Radiation Control Act (UMTRCA), Public Law 95-604 (PL95-604), was enacted to address a Congressional finding that uranium mill tailings located at inactive processing sites may pose a potential health hazard to the public. Title I of the UMTRCA authorized the DOE to enter into cooperative agreements with affected states or Indian tribes to clean up those inactive sites contaminated with uranium mill tailings and required the Secretary of Energy to designate the sites to be cleaned up. On November 8, 1979, the DOE designated 24 inactive processing sites for remedial action under Title I of the UMTRCA, including the inactive uraniferous lignite ashing sites at Belfield and Bowman, North Dakota (44FR 74891-92) (December 18, 1979).

On February 23, 1983, the DOE and the state of North Dakota entered into a cooperative agreement under the UMTRCA. The cooperative agreement set forth the terms and conditions for remedial action efforts including the DOE's development of a remedial action plan, the DOE's preparation of an appropriate environmental document, real estate responsibilities, and other concerns. 
SITE DESCRIPTION: The Belfield and Bowman sites are located in Stark and Bowman Counties, respectively, in south western North Dakota. The Belfield designated site covers 10.7 acres [ 4.3 hectares (ha)] and contains ash-contaminated soil. Commercial, light industrial, and agricultural activities have occurred within the site boundary. An additional 21 acres ( 8 ha) are contaminated by windblown materials. There are an estimated 58,000 cubic yards $\left(y d^{3}\right)[44,000$ cubic meters $\left(\mathrm{m}^{3}\right)$ ] of contaminated materials present on the designated site and windblown areas. The Belfield site is 1 mile $(1.6 \mathrm{~km})$ southeast of the town of Belfield. There are no residents near the site.

The Bowman designated site covers 12.1 acres ( 4.9 ha) and contains ashcontaminated soils. Windblown contamination covers an additional 59 acres (24 ha) off site. The site is overgrown with nonnative grass and is otherwise vacant. An estimated $100,400 \mathrm{yd}^{3}\left(76,800 \mathrm{~m}^{3}\right)$ of contaminated materials are present on the designated site or within windblown areas. There is an occupied farmhouse approximately 500 feet $(150 \mathrm{~m})$ north of the site. The Bowman site is approximately 7 miles $(11 \mathrm{~km})$ northwest of the town of Bowman.

PROPOSED ACTION: The proposed action is to relocate the contaminated materials at the Belfield site to the Bowman disposal site for codisposal with the Bowman contaminated soils. The permanent disposal cell would contain a total of $158,400 \mathrm{yd}^{3}\left(121,100 \mathrm{~m}^{3}\right)$ of contaminated 
material and soils and rise to a maximum height of 35 feet $(\mathrm{ft})$ [11 meters $(m)]$. The final restricted site would cover 12.1 acres (4.9 ha) of privately owned agricultural land. A multilayered rover system and various erosion control measures were incorporated into the engineering design to ensure the long-term stability of the permanent disposal cell. An analysis of the major cell features indicates the concentrations of contaminants entering the groundwater would meet either the U.S. Environmental Protection Agency (EPA) Maximum Concentration Limits (MCL) or background levels in the uppermost aquifer at the point of compliance (POC) at the disposal cell.

After site preparation, the remedial action would include excavating the contaminated soil at the Belfield site and hauling the materials $65 \mathrm{mi}$ $(105 \mathrm{~km})$ by truck to the Bowman site for codisposal with the Bowman contaminated soils. Trucks would use existing Federal Highways (US-85, US-12) to access the disposal site. The contaminated material would be placed on the prepared foundation soils, consisting of contaminated soil left in place within the footprint of the above-grade stabilized pile. Contaminated demolition rubble from the Belfield site also would be transported by truck to the Bowman disposal site and placed on the stabilized disposal cell. Contaminated soil from the Bowman site and vicinity properties would then be excavated and placed in the stabilized disposal cell. The rectangular disposal cell (including the cover and 
rock apron) would cover almost 10 acres (4 ha), measuring $740 \mathrm{ft}(226 \mathrm{~m})$ by $575 \mathrm{ft}(175 \mathrm{~m})$ and rising to a maximum height of $35 \mathrm{ft}(11 \mathrm{~m})$.

The final site license would be awarded to the DOE by the U.S. Nuclear Regulatory Commission (NRC) after the NRC has approved the final site surveillance and maintenance plan.

ENVIRONMENTAL IMPACTS: The subject EA assesses the cumulative environmental impacts that would result from the proposed remedial action. This FONSI for stabilization at the Belfield and Bowman ashing sites is based on the following findings, which are supported by the information and analyses in the EA.

Air quality impacts: There would be no significant anticipated deterioration of air quality during the proposed action. Activities related to the remedial action are predicted to result in temporary increases in fugitive dust emissions. However, the release of fugitive dust would be effectively reduced by dampening contaminated material with water or chemical dust suppressants and by limiting the handling of contaminated material during adverse weather conditions. An air quality monitoring $\mathrm{plan}$ approved by the state of North Dakota would be developed by the DOE prior to the start of remedial actions. 
Monitoring for fugitive dust would be done at intervals specified in the air quality monitoring plan. The plan would ensure that all applicable Federal and state air quality standards are met during the remedial action.

Groundwater Contamination: Because of the diffuse nature of the contaminant source (airborne ash), the development of contaminant plumes in groundwater is minimal. Groundwater from the shallow aquifer systems is used for limited stock-watering and some domestic purposes, but not as a source of drinking water. These uses are not affected by existing levels of contamination. Drinking water supplies are derived from higher-quality groundwater drawn from deeper aquifer systems.

After all contaminated materials are removed from the Belfield ashing site, groundwater contamination levels would decrease through time.

A groundwater monitoring program would be carried out during and after the remedial action period to demonstrate that the initial performance of the disposal unit is in accordance with the design requirements, and to ensure compliance of the disposal site with the proposed standards. Groundwater in the uppermost aquifer would be monitored downgradient from the disposal cell at the POC. Existing DOE monitor wells would be used where applicable, and new monitor wells would be installed as 
necessary. Background water quality also would continue to be monitored upgradient from the disposal cell.

Wildife: This remedial action would result in the temporary disturbance of wildlife habitat during the removal of the contaminated solls and vegetation at the Belfield and Bowman sites. There would be potential short-term losses of habitat to resident wildi ife.

Vegetation: There would be short-term losses of all existing vegetation, which would result from clearing the contaminated areas. A long-term positive benefit would occur from reseeding with endemic plant species.

Threatened And Endangered (T\&E), And Federal Candidate Species: There are no T\&E species known to be present within the areas that would be affected by remedial action activities.

Wetlands And Unique Habitat: About 2 of 4 acres ( 0.8 of 1.6 ha) of wooded draw habitat in the wetlands area along the Heart River would not be affected by remedial action. Supplemental standards would be applied to the remaining 2 acres ( 0.8 ha) to preserve this unique habitat.

The wetland/wooded draw unique habitat is outside the designated site area. Subpart $C$ of the EPA standards allows the DOE to apply 
supplemental standards if remedial actions to satisfy cleanup standards for land [40 CFR 192.12(a) and (c)] would directly produce environmental harm that is clearly excessive compared to the health benefits to persons living on or near the site, now or in the future [40 CFR $192.21(b)]$.

Land Use: There would be a permanently restricted site area of 12 acres ( 5 ha) and a release of 89 acres ( 36 ha) for unrestricted use.

Socioeconomic: There would be short-term increases in local employment related to the Uranium Mill Tailings Remedial Action Project and projected direct and indirect expenditures of $\$ 3,167,000$.

Transportation: There would be short-term (7-month) increases in traffic on US-12 and US-85 by commuting remedial action workers to the Belfield and Bowman sites. However, all roads could easily accommodate the additional traffic related to the remedial action without adversely affecting local use.

Cultural Resources: Prior to the onset of remedial action, the State Historic Preservation Office would be contacted to ensure that all potentially disturbed areas have been cleared as insignificant. In the event that cultural resources were identified during the remedial action, all work would be stopped in the area of the find until proper 
evaluation was completed and the find was efther collected or sufficient data was retrieved.

Floodplain Statement of Findings: This Statement of Findings is prepared pursuant to 10 CFR 1022, Compliance with Floodplains/Wetlands Environmental Review Requirements. Under authority granted by the UMTRCA of 1978, the DOE proposes to clean up the residual radioactively contaminated solis and materials at the inactive uraniferous lignite ashing sites at Belfield and Bowman, North Dakota. Radioactively contaminated materials are present in the 100- and 500-year floodplains of the North Branch of the Heart River at the Belfield ashing site. On the basis of the floodplain/wetlands assessment prepared as part of the $E A$, the DOE has determined that there is no practicable alternative to the proposed remedial activities and that the proposed remedial action has been designed to minimize potential harm to or within the floodplain of the Heart River at the Belfield site. 


\section{ALTERNATIVES TO THE PROPOSED ACTION}

All alternatives to the proposed action, except the no action alternative, were discussed and dismissed from further analysis in the EA.

NO ACTION ALTERNATIVE: The no action alternative consists of taking no steps toward remediation of the Belfield and Bowman sites. The principal potential hazard associated with the contaminated material results from the production of radon, a radioactive decay product of the radium contained within the tallings. Radon is an inert gas and can diffuse through the contaminated material and be released into the atmosphere where it and its radioactive decay products may be inhaled by humans, which poses a risk of lung cancer. Potential cancer hazards may also be created by exposure to gamma radiation, the inhalation of airborne radioactive particulates, the ingestion of contaminated food produced in the areas around the designated sites, and the ingestion of surface and groundwaters contaminated by the ash piles. Under this alternative, groundwater would continue to degrade as the result of seepage. The selection of this alternative would not be consistent with the expressed intent of Congress in enacting the UMTRCA and would result in noncompliance with applicable EPA standards. Thus, the no action a1ternative is not acceptable. 
DETERMINATION: In summary, based on the analyses in the EA, the DOE has determined that the proposed action does not constitute a major Federal action significantly affecting the quality of the human environment within the meaning of the NEPA of 1969 (423 U.S.C. et seq.). Therefore, the preparation of an environmental impact statement is not required.

Issued at Washington, D.C., this day of 1992.

PauT L. Ztemer, Ph.D. Assistant Secretary.

Environment, Safety and Health 

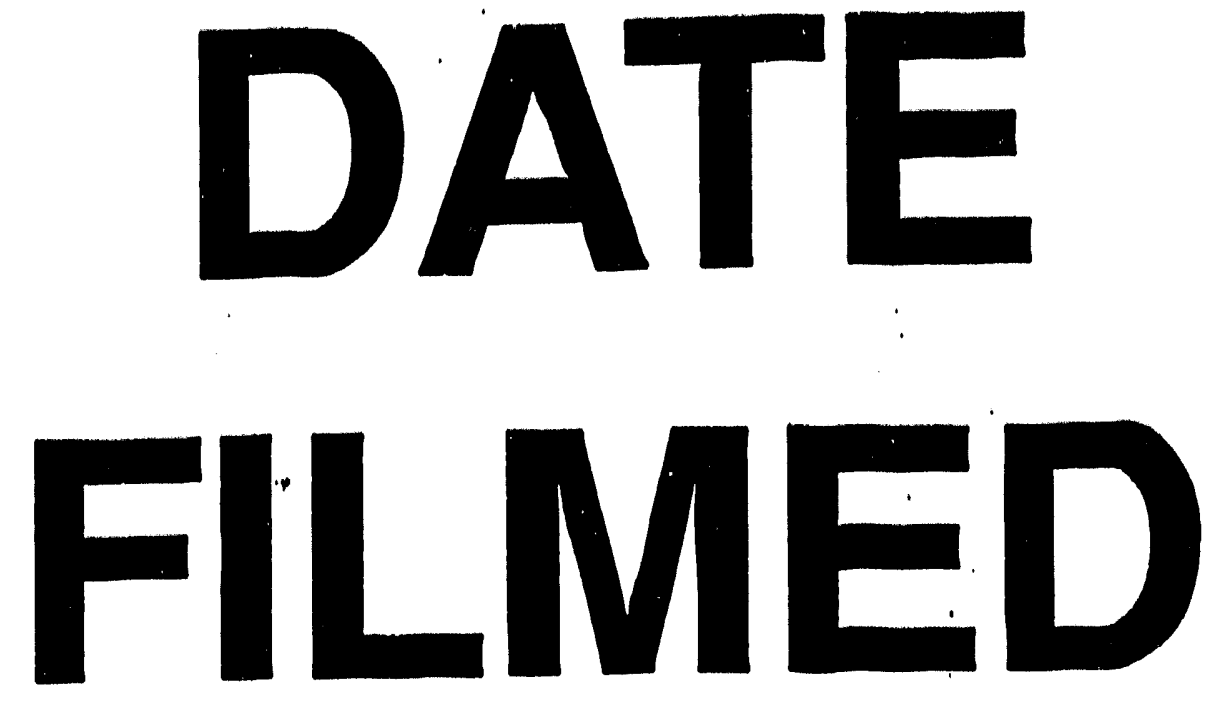

$12 / 13 / 93$
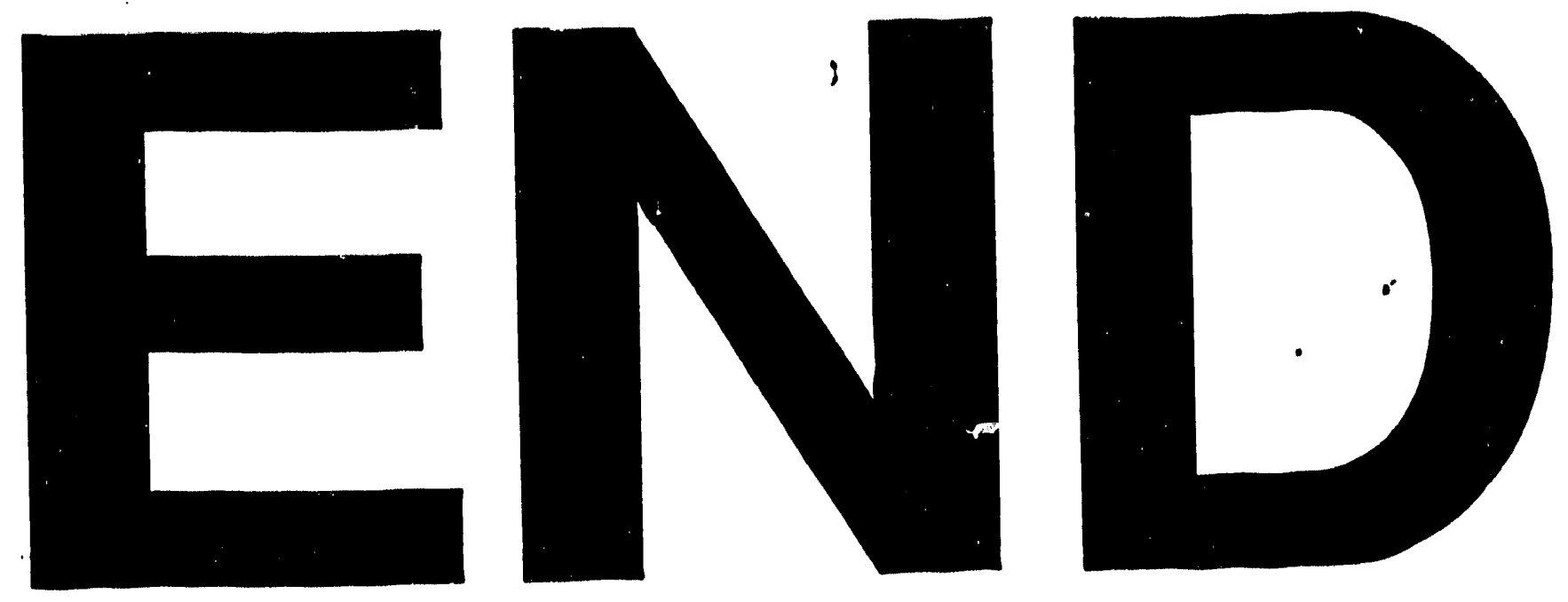